Philipp Sandermann (ed.)

\title{
The End of Welfare as We Know It?
}

Continuity and Change in Western Welfare State Settings and Practices 
The End of Welfare as We Know It? 
Philipp Sandermann (ed.)

\section{The End of Welfare \\ as We Know It?}

Continuity and Change in Western Welfare State Settings and Practices

Barbara Budrich Publishers

Opladen • Berlin • Toronto 2014 
An electronic version of this book is freely available, thanks to the support of libraries working with Knowledge Unlatched. KU is a collaborative initiative designed to make high quality books Open Access for the public good. The Open Access ISBN for this book is 978-3-8474-0338-8. More information about the initiative and links to the Open Access version can be found at www.knowledgeunlatched.org

(C) 2014 This work is licensed under the Creative Commons Attribution-ShareAlike 4.0. (CCBY-SA 4.0)

It permits use, duplication, adaptation, distribution and reproduction in any medium or format, as long as you share under the same license,

give appropriate credit to the original author(s) and the source, provide a link to the Creative Commons license and indicate if changes were made.

To view a copy of this license, visit https://creativecommons.org/licenses/by-sa/4.0/

(C) 2014 Dieses Werk ist beim Verlag Barbara Budrich GmbH erschienen und steht unter der Creative Commons Lizenz Attribution-ShareAlike 4.0 International (CC BY-SA 4.0): https://creativecommons.org/licenses/by-sa/4.0/

Diese Lizenz erlaubt die Verbreitung, Speicherung, Vervielfältigung und Bearbeitung bei Verwendung der gleichen CC-BY-SA 4.0-Lizenz und unter Angabe der UrheberInnen, Rechte, Änderungen und verwendeten Lizenz.

\section{(c) $($ (i) (2)}

This book is available as a free download from www.barbara-budrich.net (https://doi.org/10.3224/84740075). A paperback version is available at a charge.

The page numbers of the open access edition correspond with the paperback edition.

$$
\begin{array}{ll}
\text { ISBN } & 978-3-8474-0075-2 \text { (paperback) } \\
\text { eISBN } & 978-3-8474-0338-8 \text { (PDF) } \\
\text { DOI } & 10.3224 / 84740075
\end{array}
$$

Verlag Barbara Budrich GmbH

Stauffenbergstr. 7. D-51379 Leverkusen Opladen, Germany

86 Delma Drive. Toronto, ON M8W 4P6 Canada

www.barbara-budrich.net

A CIP catalogue record for this book is available from

Die Deutsche Bibliothek (The German Library) (http://dnb.d-nb.de)

Jacket illustration by Bettina Lehfeldt, Kleinmachnow -

www.lehfeldtgraphic.de

Typesetting: R + S, Redaktion + Satz Beate Glaubitz, Leverkusen 


\section{Contents}

\section{What Is a Welfare State, and What Is Welfare? Opening Reflections}

\section{Philipp Sandermann}

Change and Continuity in Western Welfare Practices: Some

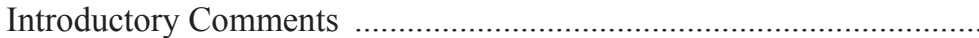

John Clarke

The End of the Welfare State? The Challenges of Deconstruction and Reconstruction

\section{Comparative Analyses of Western Welfare State Settings}

Sigrid Leitner

Varieties of Familialism: Developing Care Policies in Conservative

Welfare States

Jamie Peck \& Nik Theodore

On the Global Frontier of Post-Welfare Policymaking: Conditional Cash Transfers as Fast Social Policy

Richard Münchmeier

Regulating the Poor-Revisited: Notes on the Shifting Relationship of Social Policy and Social Work in the German Welfare State 


\section{Case Studies on Continuity and Change in Selected Western Welfare State Settings}

Robert P. Fairbanks II

Recovering Post-Welfare Urbanism in Philadelphia and Chicago:

Ethnographic Evidence from the Informal Recovery House to the

State Penitentiary

\section{Philipp Sandermann}

The German Welfare System and the Continuity of Change

Vincent Dubois

The Functions of Bureaucratic Routines in a Changing Welfare State:

On Interactions with Recipients in French Welfare Offices

Contributors

Index 


\section{What Is a Welfare State, and What Is Welfare? Opening Reflections}





\section{Philipp Sandermann}

\section{Change and Continuity in Western Welfare Practices: Some Introductory Comments}

The title of this book refers to a phrase brought to public attention by the then U.S. presidential candidate Bill Clinton in 1992, when he announced his plan to "end welfare as we know it" (Clinton, 2006). In television advertisements and stump speeches across the country, Clinton popularized the phrase to emphasize his will to change the U.S. welfare system dramatically. Clinton's phraseology and campaign proved successful: In 1996 he was eventually able to sign the U.S. welfare reform into law, and the slogan materialized as the concrete social policy of a new era.

Compared with the phrase that Bill Clinton took out into the world, the intention of this book is a rather modest one. The studies it assembles hope to contribute to a clearer understanding of how, where, and to what extent welfare has changed since the rise of the discursive patterns that Clinton could draw on for his project of putting an end to the "old" way of thinking and conducting welfare.

Much contemporary research in the social sciences insists that there have been fundamental changes in the structures of Western welfare states since the 1970 s or 1980 s, and that we can accurately describe this development as an "end" not only of welfare, but of the welfare state and every welfare state setting in general. The central goal of this volume is to offer a more nuanced and careful analysis of the phenomena associated with that stark thesis.

This is not to deny the fundamental programmatic changes that have emerged over the last thirty to forty years of Western welfare state development. However, the volume's objective is to either support or challenge the thesis - but not simply take it for granted. Instead, we should carefully deal with it as what it is: a hypothesis. Whereas the academic debate usually accepts that the welfare state as it was known in the second half of the twentieth century has come to a definitive end, taking any further discussion of welfare state development from this starting point of seemingly assured knowledge and using such terms as "post-welfarism" and "post-welfare state" to underline the assumption, the authors of this book set out to examine the crucial question of change and continuity throughout their contributions as they ex- 
plore various Western welfare state settings in more detail. They do so with a special focus on what we could heuristically call "welfare practices."

Before going any further, the present volume's understanding of the terms "welfare," "welfare state," and "welfare practices" must be introduced. Transparency in the use of these terms is evidently of great importance to any scholarly discussion on the issue, yet they are anything but well defined, and there is substantial variation in the ways they are generally used. What do we mean by each of these terms, and why does this volume prefer "welfare practices" as its broader framework? Why not simply use the term "welfare state," or even just "welfare," in line with the title quotation from Clinton?

A minimal consensus among all of the volume's contributors may be formulated as follows:

1. The volume seeks to avoid reproducing an error that has often been made in recent decades of the transatlantic debate on Western welfare practices. This error is one that - interestingly enough - probably arose primarily out of translation processes, or at least from insufficient information on the different use of language on the two sides of the Atlantic Ocean, as Wacquant (2009) argues. When Bill Clinton promised to end U.S. welfare he was not literally speaking of putting an end to his era's welfare state in general, but to a very specific part of it, using the phrase "welfare" to refer to particular welfare state benefits. The specific welfare state benefits under attack were not the benefits directed at the upper- and middle-class majority of the U.S. population, namely those provided by the social insurance system. Instead, the narrow goal of the U.S. welfare reform of 1996 was to reduce the costs entailed by public assistance programs that offered direct cash or noncash benefits to the country's very poor. One could therefore say that Clinton's welfare reform was not a welfare state reform at all (see Wacquant, 2009: 78) but, rather, radicalized the American welfare state by cementing the system's "administrative and ideological split between 'welfare' and 'social insurance"' (Wacquant, 2009: 49). Wacquant's argument may also be applicable to the European welfare reforms witnessed during the 1990s and 2000s. Just as it seems that not the American welfare state as such but only its "welfare" component was reformed by the 1996 welfare reform act, there may have been similar developments in Europe at that time (see Palier and Thelen, 2010). These parallels can easily be identified, for example by looking more closely at the German reform labeled "Hartz IV." This focused narrowly on reducing costs in insurance-based benefit for the long-term unemployed and means-tested "social assistance," while implementing a more disciplinary treatment of its recipients (see Herz, 2012). It thus, strictly speaking, 
aimed to produce a more distinct segmentation between public assistance benefits and those provided by the social insurance system.

2. That said, it would be even more unsatisfactory to reduce the academic debate on welfare states to such specific objects as spending programs, patterns of social expenditure, or (especially) social insurance benefits. Many traditional social policy approaches do just that when they discuss specific welfare states as individual cases or various welfare states in a comparative perspective (for example Esping-Andersen, 1990; SeeleibKaiser, 2008; Starke et al., 2008; Kaufmann, 2012), thereby establishing a worthwhile, yet very limited view on welfare states and especially on welfare state development. Spending programs, patterns of social expenditure, and social insurance benefits are certainly deeply embedded in the general model of Western welfare state settings, and perhaps even stand for specific ideas of welfare practices in certain national frameworks. However, they cannot stand for the entirety of what the approaches focusing on them are actually trying to describe. This applies to more than only questions of continuity and change, but those questions make it particularly problematic: If Wacquant's thesis, quoted above, is correct even in part, the mainstream academic debate on welfare state development is far from possessing satisfactory tools and concepts to adequately observe and measure Western welfare state development, since it focuses on data that is only incoherently connected to the changes still under way. On the other hand, it seems unjustified to ignore the facts delivered by traditional social policy research. That is to say, it is quite as unfounded to take the current rise in social expenditure in most Western welfare states as a sign of unbroken welfare state expansion as it is to diagnose a general end of the Western welfare states merely because of major changes in significant, but nevertheless specific, programs of welfare provision for the poorest, usually called "relief programs" in the tradition of the term "poor relief." Additionally, contemporary welfare state research currently knows far too little about the empirical reality of public assistance and relief programs (among the useful exceptions is Leisering and Leibfried, 2001). Whereas we have quite substantial information about

1 While the English phrase "poor relief," commonly used in the past, still seems adequate to describe this field of interest in academic terms, it is problematic to simply internationalize it and to transfer it to other national contexts. For example, the German term Armenfürsorge is a rather literal translation of "poor relief" and holds great historical significance for the expansion of the German welfare state - but today the term is almost meaningless as an item of welfare vocabulary, because the German welfare state has undergone a stepwise process of differentiation in its benefits (see Sachße, 1996), nowadays programmatically differentiating "the poor" into "young people," "disabled people," "elderly people," "people in special life situations," and so on. 
the policy details and political contexts of recent Western welfare reforms, we know very little about what has actually changed in the lives of welfare professionals, institutions, and recipients due to these reforms. For example, even regarding U.S. welfare reform, the data looks quite different when we move beyond the narrow focus on the declining number of families on welfare since 1996 and the evolution of the Temporary Assistance for Needy Families (TANF) program (see Daguerre, 2008), to take into account the growing number of poor people in the United States who benefit from disability programs (see Joffe-Walt, 2013). It is not farfetched to assume that there could be a correlation between these data sets. Ultimately, there are reasons to believe that welfare reform may have changed little in the everyday life of poor people in the United States, apart from making them even more socio-economically disconnected from "normal life" because they must be labeled as disabled in order to receive at least some sort of basic income-bringing us back to Wacquant's portrayal of the "ideological split" in the American welfare state. To clarify all this, much empirical research inevitably remains to be done. That research will need to focus on the general question of how far welfare provision and reception actually change on the concrete level when relief programs are redesigned, replaced by new programs, or even completely abolished. This question is methodologically ambitious, and it becomes even more complex when we factor in those programs that are based not only on direct cash benefits (which are relatively easy to measure) but on noncash services such as counseling or educational intervention.

3. In order to initiate a more differentiated academic discussion about the continuities and changes of Western welfare states, a first step will therefore be to broaden the scope of our investigation. Not only should the focus of social policy research move beyond those realms of welfare state provision that are relatively easy to research, namely spending programs, patterns of social expenditure, and social insurance expenditures; we also need to think carefully about the interrelations, commonalities, and differences between those Western welfare practices generally marked as "relief" on the one hand and the social insurance system on the other. Although the fields of relief prove quite diverse in their detail, and may thus be harder to explore, investigate, and compare, a scholarly discussion on Western welfare states cannot simply ignore these fields if it is concerned with the question of welfare state transformation. Once again, this is all the more true because there is good reason to believe that the area of relief is exactly where the greatest changes in Western welfare state set- 
tings are occurring. Moreover, it is both politically and epistemologically alarming when, through their research designs, researchers reproduce what Wacquant calls the split of Western welfare practices into "welfare" and "social insurance." If they fail to reflect on that split, such research designs will replicate the ideas proposed by Western welfare states regarding "normal" and "abnormal" needs or social risks, along with the stigmatization that accompanies this distinction. And since the institutionalized gap between social insurance and public assistance benefits may be a feature not only of U.S. welfarism but of Western welfare state settings in general (see, for example, Letwin and Metzler, 2010: 75), research designs that re-institutionalize the gap in this way will fail to identify a very important contextual factor of their objective.

On the basis of these reflections, this volume adopts "welfare practices" as a heuristic term that represents a broader idea of Western welfare state reality, covering public assistance and social insurance alike. The contributors take different views on the development of Western welfare practices, depending on their particular focus and individual perspective. Nevertheless, every chapter in its own way reflects on both changes and continuities in the welfare practices it investigates, aiming thereby to sketch out a broader conceptual notion of Western welfare state settings more generally.

As a starting point, in the first chapter John Clarke raises the question of what a welfare state is (or perhaps was). He observes that, in the face of evidence to the contrary suggesting an unshakable growth in most Western welfare states, in recent decades some major studies have proclaimed the end of the Western welfare state model as such. Clarke regards this contradiction as the result of an argument that is consistently made in the academic discussion of Western welfare state settings: the studies identifying an end of the Western welfare state tend to construct the existence of the modern welfare state themselves, above all because they implicitly or explicitly place the concept of the Western welfare state on the same level as spending programs or patterns of social expenditure when they design their empirical research. They thus not only exclude significant parts of welfare provision, but also reduce to a minimum the diversity of meaning contained in the phrase "welfare state." Rather than trying to resolve that diversity by means of a more prescriptive and "correct" definition, Clarke treats the concept's instability, flexibility, and mobility as significant features worthy of our attention. He breaks it down into its two terms - welfare and state - in order to reflect on the problems of their meaning and the ways they have been potently combined with a third term: nation. This is no mere academic exercise, aiming to define and understand national welfare states as a theoretical entity. To exemplify points 
of national welfare state transformation, Clarke distinguishes between familialization and privatization, which enables him to show how-on a discursive level - both the private in general and welfare practices in particular are currently being familialized. He concludes that this tendency normalizes a transfer of responsibility from the public sector to private settings, ideologically naturalizing bonds of affection, obligation, and future-oriented investment (for example in children), and can therefore be regarded as a dominant change in Western welfare practices that accompanies the patterns of continuity and growth highlighted early in his chapter.

Tendencies of familialization, responsibilization, and future-oriented investment are also the focus of Sigrid Leitner's contribution. However, she chooses a different perspective to reflect on continuity and changes in Western welfare state settings, and opens Part II of the volume with an explicitly comparative approach. Her chapter addresses the national contexts of child care and elder care in Austria, Belgium, France, and Germany-four examples of "conservative" welfare capitalist regimes (Esping-Andersen, 1990: 38-41). Leitner asks how far the four cases differ in terms of their elder care and child care policies and their institutionalization of those policies. Introducing categories of familializing and de-familializing child care and elder care policies, she investigates how these four national welfare states have continuously institutionalized such policies as path-dependent, and describes how and why each country's programmatic and institutional reality has changed over time.

Jamie Peck and Nik Theodore provide the book's second comparative perspective. The two authors depict the rise (and fall) of the conditional cash transfer (CCT) programs that have spread to every continent of the world since the late 1990 s, whereby they try to establish a more transnational approach to identifying continuity and change in Western welfare practices. But this very spread raises the question of whether Peck and Theodore's chapter is really about only "Western" welfare state settings. That question goes to the heart of their study. They pursue it by underlining the role of the World Bank and other multilateral development agencies that refer to utilitarian and responsibilizing ideologies in public assistance policy. These can certainly be defined in historical terms as "Western," suggesting that the practices considered by Peck and Theodore are "Western" even when they do not occur entirely within Western welfare state settings. At the same time, the authors' discussion of CCT programs illustrates that even a powerful implementation of a programmatic design and its support through evaluation science does not in the end guarantee a particular way of conducting welfare practices. As the case of Brazil impressively shows, there is a difference between researching programmatic turns and researching their transfer into practice. 
Richard Münchmeier completes Part II, and chooses a third way of comparing different national set-ups within Western welfare state settings, namely the United States and Germany. Adopting Piven and Cloward's (1993) analytical framework on the function of public welfare policies in the United States, he examines two points: firstly, historical differences in the development of welfare practices between Germany and the United States, and secondly, the recent changes in German welfare provision. In his study of this second issue, Münchmeier focuses on the question of whether or not the "Hartz IV" reform in Germany marked the beginning of a new era for the German welfare state and thus ushered in (or is likely to usher in) an "Americanization" of welfare practices in Germany.

Part III of this volume comprises three case studies on continuity and change in selected Western welfare state settings. The analyses in this part of the book offer a different perspective by concentrating on single national contexts. Robert P. Fairbanks II explores welfare state transformation in two post-industrial U.S. cities: Philadelphia and Chicago. Fairbanks's research goal is to understand the nexus of urban poverty survival strategies and the implementation of social welfare policy and practice reforms, as embodied by the lived experience of addiction and recovery. Using the Philadelphia recovery house and the Sheridan Correctional Center as sites of ethnographic analysis, Fairbanks explores the ways in which drug and alcohol recovery-from its most informal inception in the self-help realm to state monitoring in prison and parole-works as an ancillary modality of poverty management to resolve the current crises of mass incarceration in the U.S. and to reinvent urban welfare practices in the twenty-first century.

In the second chapter of Part III, Philipp Sandermann firstly questions the popular analysis that claims we can interpret current changes in welfare practices adequately as a move towards "post-welfarism," or-in its specific German version - a move towards post-welfare statism ("Post-Wohlfahrtsstaatlichkeit"). Sandermann argues that this analysis lacks a clear theoretical delimitation of what actually constitutes a "welfare state," "social work," or- to use the heuristic term of this volume- "welfare practices." In contrast, Sandermann outlines an approach to understanding welfare practices as practices of a specific welfare system; he draws on basic arguments of contemporary systems theory to critically examine important questions around change in the German welfare state setting. At the same time, this chapter specifically brings together various analytic factors of welfare, or welfare state, development to describe the current state of the German welfare system as a combination of both change and continuity. 
Vincent Dubois completes the third part of the volume with an analysis of practices among clients and agents in French welfare offices. He draws on his own ethnographic research on the relationships between agents and recipients at the front desks of family benefit offices to show the importance of these face-to-face administrative interactions. Dubois makes the point that such interactions are gaining in importance in line with the unprecedented decline in objective social rights and the worsening of socio-economic problems. The concrete welfare practices co-produced by agents and recipients at the front desks of welfare offices are therefore far from being neutral routines of policy implementation. Instead, Dubois argues, the relational and bureaucratic work in welfare offices constitutes the very core of welfare practices.

Edited volumes like this one are always the product of collaboration on many levels. I would like to thank the following people and institutions involved in the project. My foremost thanks go to the authors collected in the volume, every one of whom contributed commitment and extraordinary reliability during the whole process of preparing, writing, and editing the book. The book's evolution goes back to a series of public lectures at the University of Trier with almost the same title, and I would also like to thank the authors for their contributions to that series. I express my gratitude to the whole Social Pedagogy II Unit at Trier University for their help and enthusiasm: Julia Gill, Onno Husen, Magdalena Joos, Duygu Kececi, Mareike Patschke, and Shadi Rajabi were all actively involved in organizing the lecture series and discussing each contribution with our colleagues from abroad. I also thank the president of Trier University, Michael Jäckel, the Freundeskreis Trierer Universität, and the Nikolaus Koch Stiftung for their support. Special thanks go to Alexandra Lemonides and Kate Sturge, kind and helpful translators and copy editors for the volume, and to Duygu Kececi, who supported me throughout the editing process.

\section{References}

Clinton B (2006) How We Ended Welfare, Together. The New York Times, August 22, p. 10.

Daguerre A (2008) The Second Phase of US Welfare Reform, 2000-2006: Blaming the Poor Again? Social Policy \& Administration 42 (4): 362-378.

Esping-Andersen G (1990) The Three Worlds of Welfare Capitalism. Cambridge: Polity Press.

Herz B (2012) Punitive Trends in Germany: New Solutions for Deviant Behaviour or Old Wine in New Bottles? In: Visser J, Daniels H and Cole T (eds) Transforming Troubled Lives: Strategies and interventions for children with social, emotional and behavioural difficulties. London: Sage, 389-403.

Joffe-Walt C (2013) Unfit for Work: The Startling Rise of Disability in America. Available at: http://apps.npr.org/unfit-for-work. 
Kaufmann F-X (2012) Variations of the Welfare State: Great Britain, Sweden, France and Germany Between Capitalism and Socialism. Heidelberg: Springer Verlag.

Leisering L and Leibfried S (2001) Time and Poverty in Western Welfare States: United Germany in Perspective. Cambridge: Cambridge University Press.

Letwin D and Metzler G (2010) Welfare: Entitlement and exclusion. In: Mauch C and Patel K K (eds) The United States and Germany During the Twentieth Century: Competition and Convergence. New York: Cambridge University Press, 70-84.

Palier B and Thelen K (2010) Institutionalizing Dualism: Complementarities and Change in France and Germany. Politics and Society 38 (1): 119-148.

Piven FF and Cloward RA (1993) Regulating the Poor. The Functions of Public Welfare. Updated edition. New York: Vintage Books.

Sachße C (1996) Public and Private in German Social Welfare: The 1890s to the 1920s. In: Katz MB and Sachße C (eds) The Mixed Economy of Social Welfare: Public-private Relations in England, Germany and the United States, the 1870s to the 1930s. BadenBaden: Nomos Verlagsgesellschaft, 148-169.

Seeleib-Kaiser M (ed) (2008) Welfare State Transformations: Comparative Perspectives. Basingstoke: Palgrave.

Starke P, Obinger H and Castles FG (2008) Convergence Towards Where: In What Ways, if Any, are Welfare States Becoming More Similar? Journal of European Public Policy 15 (7): 975-1000.

Wacquant L (2009) Punishing the Poor: The Neoliberal Government of Social Insecurity. Durham: Duke University Press. 



\section{John Clarke}

\section{The End of the Welfare State? The Challenges of Deconstruction and Reconstruction}

Over the last four decades, the crisis of the welfare state and the end of the welfare state have been announced many times. Such claims are certainly dramatic and attention catching. But they also raise some problems: conceptual, empirical and political. The first set of problems (conceptual) concerns the assumption that we know what a welfare state is. The second set of problems (empirical) concerns the assumption that we would be able to tell when the welfare state had ended. The third set of problems (political) concerns the anticipated response to the announcement of the welfare state's death. In this chapter, I will explore these problems and argue that - for social scientiststhey result from a sort of conflation of conceptual, empirical and political presumptions about welfare states. Instead, I will suggest that we might gain some analytical advantage by deconstructing the term 'welfare state' and thinking of it in different ways - as a form of institutionalized assemblage and as a political "keyword"-in the sense that Raymond Williams used the term (see Williams, 1976).

Such a deconstructionist approach to the problem of welfare states may enable us to think better about how they are being reconstructed. This approach explores how the two terms - welfare and state and their institutionalization as "welfare states" - have become destabilized and unsettled in practice. What happens when taken for granted terms become problematic?

\section{Accounting for Welfare States}

But let us begin at the beginning: we all know (do we not?) that we have seen the end of the welfare state. Sociologists, political scientists, economists, geographers and others have queued up to pronounce the funeral oratory: once there was a welfare state, but now neo-liberalism, globalization, postfordism, or advanced liberal governmentality (take your pick of the contemporary grand narratives) have demolished, diminished and destroyed it. 
Table 1 OECD Government social spending: Total public social expenditure as a percentage of GDP

\begin{tabular}{|c|c|c|c|c|c|}
\hline & 1980 & 1990 & 2000 & 2005 & 2011 \\
\hline Australia & 10.3 & 13.2 & 17.3 & 16.5 & 18.1 \\
\hline Austria & 22.4 & 23.8 & 26.6 & 27.1 & 27.9 \\
\hline Belgium & 23.5 & 24.9 & 25.3 & 26.5 & 29.6 \\
\hline Canada & 13.7 & 18.1 & 16.5 & 16.9 & 18.3 \\
\hline Chile & - & 9.9 & 12.8 & 10.1 & 9.5 \\
\hline Czech Republic & - & 15.3 & 19.1 & 18.7 & 20.9 \\
\hline Denmark & 24.8 & 25.1 & 26.4 & 27.7 & 30.0 \\
\hline Estonia & - & - & 13.9 & 13.1 & 18.8 \\
\hline Finland & 18.1 & 24.1 & 24.2 & 26.2 & 28.6 \\
\hline France & 20.8 & 25.1 & 28.6 & 30.1 & 32.1 \\
\hline Germany & 22.1 & 21.7 & 26.6 & 27.3 & 26.2 \\
\hline Greece & 10.3 & 16.6 & 19.3 & 21.1 & 23.5 \\
\hline Hungary & - & - & 20.7 & 22.5 & 21.8 \\
\hline Iceland & - & 13.7 & 15.2 & 16.3 & 17.8 \\
\hline Ireland & 16.5 & 17.3 & 13.4 & 16.0 & 23.5 \\
\hline Israel (1) & - & - & 17.2 & 16.3 & 15.8 \\
\hline Italy & 18 & 19.9 & 23.1 & 24.9 & 27.6 \\
\hline Japan & 10.2 & 11.1 & 16.3 & 18.5 & $\mathrm{n} / \mathrm{a}$ \\
\hline Korea & - & 2.8 & 4.8 & 6.5 & 9.2 \\
\hline Luxembourg & 20.6 & 19.1 & 20.9 & 22.8 & 22.5 \\
\hline Mexico & - & 3.3 & 5.3 & 6.9 & 7.7 \\
\hline Netherlands & 24.8 & 25.6 & 19.8 & 20.7 & 23.7 \\
\hline New Zealand & 17 & 21.5 & 19 & 18.1 & 21.5 \\
\hline Norway & 16.9 & 22.3 & 21.3 & 21.6 & 22.6 \\
\hline Poland & - & 14.9 & 20.5 & 21.0 & 20.7 \\
\hline Portugal & 9.9 & 12.5 & 18.9 & 23.0 & 25.2 \\
\hline Slovak Republic & - & - & 17.9 & 16.3 & 18.0 \\
\hline Slovenia & - & 0 & 21.8 & 21.1 & 24.0 \\
\hline Spain & 15.5 & 19.9 & 20.2 & 21.1 & 26.0 \\
\hline Sweden & 27.1 & 30.2 & 28.4 & 29.1 & 27.6 \\
\hline Switzerland & 13.8 & 13.5 & 17.8 & 20.2 & 20.2 \\
\hline Turkey & 3.2 & 5.7 & - & 9.9 & $\mathrm{n} / \mathrm{a}$ \\
\hline United Kingdom & 16.5 & 16.7 & 18.6 & 20.5 & 23.9 \\
\hline United States & 13.2 & 13.6 & 14.5 & 16.0 & 19.7 \\
\hline OECD total (2) & 15.5 & 17.6 & 18.9 & 19.7 & 21.7 \\
\hline
\end{tabular}

Last updated: 16 November 2012; disclaimer: http://oe.cd/disclaimer

(1) The statistical data for Israel are supplied by and under the responsibility of the relevant Israeli authorities. The use of such data by the OECD is without prejudice to the status of the Golan Heights, East Jerusalem and Israeli settlements in the West Bank under the terms of international law.

(2) Refers to an unweighted average of 33 OECD countries and Estonia

Source: Social expenditure: Aggregated data, OECD Social Expenditure Statistics (database) Adapted from: http://dx.doi.org/10.1787/20743904-2012-table1 and OECD Stat Social Expenditure-Aggregated data (28.01.2013)

Such definitive pronouncements contrast strikingly with a stubborn set of empirical details that are well known to those working in comparative social 
policy studies. European Union data indicates that between 1980 and 2011 the proportion of Gross Domestic Product (GDP) committed by OECD (Organisation for Economic Cooperation and Development) countries to social expenditure largely stayed the same, even increasing in some cases (see Table 1). The data covers a period that contains several economic, financial and fiscal crises - and several proclaimed ends of the welfare state.

Such data pose several puzzles: is social expenditure the same as welfare? Are such data a satisfactory way of accounting for or representing welfare states? How is the persistence of such spending patterns to be accounted for? Do the data disguise changes that take place below or beyond such spending patterns? The problems of selecting specific indicators as proxies for welfare states are extensively discussed in the social policy literature (see, inter alia, Skyes, 1998; Daly, 2000; Castles, 2004; Clasen, 2007; Clasen and Siegel, 2008), but these tend to center on the contested principles of selection-the adequacy, the focus (the relative visibilities and invisibilities that are created), or the comparability of the data sets selected. They rarely extend to the conceptual problem of the relationship between the proxy and the object being discussed (but see Clasen and Siegel, 2008, on the "dependent variable" problem for a different approach). For instance, Castles sets up his use of the OECD Social Expenditure Database by noting that: "In respect of the majority of chapters focusing on social expenditure trends, an important preliminary point to recognize is that spending is not the be-all and end-all of the welfare state" (Castles, 2004: 14). But in what follows, the other things that might make up the welfare state remain resolutely invisible, obscured by the might (and availability) of the expenditure data.

Nevertheless, whatever empirical and conceptual problems surround these figures, the data exist; they demand our attention and-however crudelythey suggest that the grand narratives about the end of the welfare state have to account for them, rather than ignore them. Ignoring them has typically been the position of choice for those interested in the grand narratives, where "welfare state" (or its political-ideological alter ego, "welfarism") has tended to be used as a symbolic counterpoint to the contemporary trends and transformations that command attention. So the welfare state has variously been mythologized as the victim of globalization; as subordinated to the economic interests and logics driving the rise of neo-liberalism; or as lost in the "death of the social" in the face of advanced liberal governmentality (Rose, 1996).

Such representations treat the welfare state as the emblematic representation of something (social democracy; the triumph of the social/political over markets; collectivism rather than individualism; government from a "social" point of view), rather than as a specific - and complex — object in its own 
right. Such mythologies capture something of the popular political-cultural symbolism and significance of the idea of the "welfare state," but they pay relatively little attention to the empirical questions of what states do by way of welfare. They treat the welfare state as a normative symbol-embodying a certain progressive or benevolent set of political and policy developments. This normative orientation to benevolence is, of course, not shared by Foucauldian approaches which tend to a bleaker view of governmental policies and practices.

This leads to a different analytic puzzle: how might we make sense of the persistence of high levels of welfare spending during the period when the welfare state was supposedly in decline, retreat or crisis? There are many different answers. Some stress the dynamics of survival and resilience; others the sheer weight of either path dependency or the impact of demography (notably the costs of increasingly elderly populations in Europe and North America); e.g., Castles (2004) and Kuhnle (2000) have focused on the dynamics of survival and resilience, while Pierson (2004) has emphasized "path dependency" in the institutional logics of welfare states. Some have pointed to the relation between continued social welfare spending and the changing roles and functions of the state, moving from direct provision to regulated contracting out or disaggregation (e.g., see Seeleib-Kaiser, 2008). Others have argued that the persistence of aggregate spending may disguise changing strategies and objectives that rework the form and dynamics of the welfare state. Authors such as Peck (2001), Hartmann (2005) and Ellison (2006), have identified changing strategies and objectives in the processes of what Jones and Novak (1999) termed the "retooling" of the state.

Nevertheless, almost all of these answers ignore a conceptual problemthe question of what is (or was) a welfare state? Studies of welfare states have tended to assume the existence of a specific object of analysis - the welfare state (or sometimes its plural companion, welfare states). This assumption has some troubling consequences. On the one hand, it means that conceptual difficulties about the character of welfare states are avoideddisplaced by a presumption that authors and readers will share a common, or take-for-granted, conception of welfare state-ness. As usual in the social sciences, taken-for-granted assumptions or forms of knowledge should be marked "handle with care." On the other hand, the lack of conceptual attention leads directly into a casual empiricism - in which more specific objects are allowed to stand for welfare states. Typically, these are spending programs or patterns of social expenditure (as above).

In what follows, I raise some questions about how we understand the "welfare state" as a concept and link these to recent developments in study- 
ing states as compound entities. Terms such as assemblages, constellations, and articulated formations point to new possibilities that might, and perhaps, ought to be extended to thinking about welfare state-ness (see the more extended discussion in Clarke, 2008). I then suggest that thinking about welfare states as formations that articulate welfare, state and nation can illuminate the different, and potentially divergent, dynamics of transformation that are at stake in the reconstruction of welfare states.

\section{Deconstructing and Reconstructing Welfare States}

I am not the first to make the claim that the welfare state is too readily taken as an obvious and self-evident object of analysis. As long ago as 1963, Richard Titmuss raged against the elusive and ill-defined character of the phrase, arguing that it should be bracketed in quotation marks (see Veit-Wilson, 2000). Perhaps more important was Titmuss' recognition that the phrase moved - and was given meaning - in the realm of popular consciousness. The prolific and elusive usage of "welfare state" is testimony to its political and cultural currency. It is a marker or a symbol of something important in popular understandings and political discourse. At the same time, the fluidity of its use and the absence of rigorous definition mark it out as a contingent symbol whose meanings are variable and contested so that the phrase "welfare state" marks the site of major political and cultural conflicts. Where social democrats and progressives have treated the welfare state as a symbol of modernity, equality and progress, the New Right made it a negative symbol identifying the welfare state as the cause of, rather than solution to, social problems. This is exemplified in the assertion by Milton and Rose Freidman in the early 1980s that "The Soviet Union is the immediate danger perceived by Americans. Yet it is not the real threat to our national security. The real threat is the welfare state" (Freidman and Freidman, 1984: 73). The idea of the "welfare state" has served as a potent mobilizing symbol for a variety of political projects. It is precisely this murkiness of the term-its multiple political, cultural and normative capacities and valences - that makes it interesting. Rather than trying to resolve this diversity of meaning by a more prescriptive and "correct" definition of the phrase, I want to treat its instability, flexibility and mobility as significant features worthy of our attention.

My starting point then, is to recognize the welfare state as a variable social construction (historically and nationally). Then we can deconstruct the phrase "welfare state" - and, I will suggest, its conceptual shadow, the nation-state - in order to see why it might be hard to categorize and conceptu- 
alize welfare state change or transformation. In these terms, we need to think about the welfare state as an invention-a political-cultural fiction-an imaginary (Lewis, 2000). The wide public and academic circulation of the phrase since then suggests that it functions as what Raymond Williams (1976) called a "keyword:" a focus of political and cultural investment and contestation. Here, I want to decompose the phrase into its two termswelfare and state - to reflect on the problems of their meaning as well as how they have been brought together into such a potent combination with a third term-nation (since welfare states have been imagined as nation-states).

\section{Welfare:}

Welfare is both abstractly elusive and concretely difficult to specify. Sykes has rightly argued in relation to comparative studies of welfare state divergence and convergence, there are important questions of what policies should be considered and why (see Sykes, 1998:14). I have already suggested that comparative studies have tended to ignore these questions, preferring to treat welfare states as if they were income transfer programs. But where does this orientation leave public services such as health care, social care, housing or education? Comparative studies - as well as national ones - have also tended to treat income transfer programs as acting on a limited number of social axes, typically, socio-economic strata and age groupings (or "class" and life cycle distributions). However, social policies, programs and practices also act on and enact other social relationships - not least those of racialized or ethnicized divisions, formations of able-bodiedness and disability, and gendered divisions of labor. These include welfare practices and relationships formed at the intersection of the state and the family (more accurately, the private, household or domestic realm). Such policies and practices are harder to observe and quantify than the income transfer programs and have typically been left out of account by welfare state studies.

There are also other state policies and practices with significant social dimensions - such as criminal justice and leisure provision- that are rarely included as elements of welfare states, or thought worthy of inclusion in social policy (see, for scarce examples, Cook, 2006, and the chapters by Clarke, A., Muncie and Stenson in Lewis et al., 2000, as well as the chapter by Robert Fairbanks in this volume). Along with overseas aid programs, these might be thought of as welfare-related things that states do in different ways. Some commentators have argued that the very high levels of incarceration in the U.S. prison system can be seen as a functional alternative to male unemployment programs and as a means of managing a "problem population" (see Christie, 1996; Morley and Petras, 1998; Wacquant, 2009). However, penal 
policies are not conventionally counted as welfare or included in studies of social policy or welfare states. Welfare normally, and normatively, excludes other state policies and practices that might be understood as contributing to social order, social regulation, social reproduction and the management of complex social populations.

Examinations of this wider range of state practices involved in "governing the social" have tended to emerge from critical standpoints-e.g., feminist, marxist, post-structuralist and post-colonial studies (see, inter alia, Offe, 1984; Jones and Novak, 1999; Petersen et al, 1999; Lewis, 2000; Daly, 2000). In such studies, we can glimpse of forms of social differentiation and inequality that go beyond the conventional focus on class as either a distributional field or a set of economic relations. We can also catch sight of the role of the state in shaping, defining and managing the field of social groups who make up the "nation" served by welfare (and those who are excluded from it). Such approaches also call into question the assumptions that "welfare" is intrinsically benevolent and that its recipients (as users, clients or customers) desire welfare provision. Instead, questions of control, regulation, surveillance, and the norms embedded in such processes require us to think of the relationships between welfare, states and citizens in a more difficult way. Such approaches also suggest that these relationships have a long history, rather than simply being an effect of the contemporary move away from a benevolent welfare state to a harsher form of politics and policies (see, e.g., Somers, 2010).

In all these ways, it seems important not to short-circuit the analysis of welfare states with assumptions about their content (e.g. income transfer programs), their (re)distributive dynamics or their social/political character. Attending to the diversity of programs and processes through which "welfare" is organized and enacted certainly makes comparison (across space and time) more difficult, but possibly more productive. From such a starting point, studying welfare state change demands our attention to a range of governmental programs and their impacts on differentiated populations. That certainly means, as Clasen and Seigel (2008) have argued, attention to the changing conditions and conditionalities of welfare provision. How are the claims of universalism being varied? How are the forms of inclusion and exclusion of welfare subjects changing? What is at stake in the proclaimed "rebalancing of rights and responsibilities" between citizens and the state? What is the experience of welfare when one is made into an active and responsible citizen? What disqualifications are brought into play in the "reform" of welfare benefits and services? E.g., the withdrawal of benefit from people (women) who have children while in receipt of welfare; who are found to use 
illegal drugs; who refuse "offers" of work or work experience; who live in housing that is "too expensive"... and many more. What Jeremy Gould has called "the new conditionality" (Gould, 2005) is increasingly widespreadand is by no means limited to development policies.

Finally, thinking about the conditions and consequences of welfare policies opens up further questions about (re-)distribution. Some analysts have argued that the reform of welfare - particularly in Anglophone settings-has seen a move towards "corporate welfare" (Farnsworth, 2012). A variety of changes, such as public-private partnerships, outsourcing or contracting of services, involve an "income transfer" process to corporations who have become major "welfare beneficiaries." There are also other transfers to the corporate sector, such as subsidies for employing people. As with questions of changing conditionality, these changes suggest that stable figures for public spending on social protection may conceal significant changes in the focus, aims and effects of such schemes.

Welfare, then, is both difficult to specify and variable, between countries and across time. Recent attempts to "reform" welfare have been primarily legitimated by reference to the costs of welfare (in a long series of fiscal crises since the 1970s) and to the consequences of welfare (such as neoconservative claims about producing a "dependency culture"). These challenges to welfare have been closely tied up with neo-liberal and neoconservative anti-statism - but in the following section, I will suggest that conceptually separating welfare and state may be important.

\section{State:}

Anti-statism is certainly entangled with anti-welfarism in contemporary politics, but it has a wider reach and significance in at least two respects. First, it draws on a considerably more diverse set of political experiences and discourses-linking Hayekian neo-liberalism's hostility to state "interference" in the imagined free market to anti-totalitarian and anti-authoritarian demands to liberate people from the scrutiny and domination of the state (e.g., in former communist societies or in the dictatorships of Latin America and the Middle East). In such contexts, social democratic assumptions about the progressive and benevolent qualities of the state are- to say the leastbrought into question. Such different tendencies - partly concealed by the dominance achieved by neo-liberal orientations in the institutions of global governance - have certainly fuelled very significant programs of state reform: from the current fiscal austerity to processes of decentralization and devolution; from outsourcing public services to the promotion of civil society or third sector organizations (Newman and Clarke, 2009). 
Arguments about the state of welfare have addressed these changes in a number of different ways. Political economy accounts of the crisis or end of welfare states have tended to argue that the dominance of global capital, market relations and market forces have subordinated the social and political objectives of welfare states (see the discussion in Clarke, 2007). Elsewhere, institutionalist accounts have tended to stress the reform and retrenchment of welfare, albeit in new institutional arrangements. Here the rise of "mixed economies of welfare" (Johnson, 1996) or "welfare pluralism" (Rao, 1996) are ways of designating the shifts between different economic or organizational sectors - with corporate or third sector organizations taking on welfare functions as the state withdraws or contracts. Others have pointed to the changing scope and functions of the state in such changes, with the state surrendering roles in the direct production and distribution of welfare, retreating instead to functions of financing and regulation (see, e.g., Seeleib-Kaiser, 2008).

Such political economic, institutional and sectoral analyses have tended to neglect another dynamic of privatization; the shift towards the familyhousehold-domestic realm that I mentioned earlier. Where these analyses did not neglect this realm, they at least only grasped it as a "fourth sector" within the mixed economy.

I use the rather cumbersome formulation family-household-domestic realm intentionally. Much social policy analysis refers to this too casually as "the family." This ignores the fact that many people do not live their lives, and do not produce and consume welfare, within families. It also obscures the way in which many social policies attempt to represent the complex ways in which people organize their personal lives as families. The family is both the normalized and normative conception of the "private" realm in most European societies.

The "sectoral" view of the mixed economy of welfare finds it difficult to accommodate this realm satisfactorily. It is not a sector, comparable to the other three named sectors. It is not organized by economic logics of calculation or forms of coordination. There may be "contracts"-e.g. for marriages or civil partnerships - but they are not the means of organizing and regulating welfare transactions. Specific households may be organized around particular relationships, commitments and expectations - but they are not organizations equivalent to welfare bureaucracies, commercial corporations or nongovernmental organizations. Despite increasing efforts to estimate their economic value, they are not subject to the calculations of the economic value of welfare providing sectors or organizations. They are certainly the focus of governmental interventions, directions and attempts at regulation-but they 
are not directly or tightly coupled into the changing mix of welfare. Despite claims about how the market is taking over more areas of social life, the provision of welfare in this intimate sphere is at least partly driven by logics of attachment, obligation, concern and even desire. These are not easily rendered controllable, nor can they be easily subjected to current governmental obsessions with performance management and evaluation.

Of course, states regulate some aspects of this private or personal realm, especially in relation to the care of children. They also, of course, fund certain practices and forms of relationship (tax incentives for married couples; parental leave; allowances for carers and so on). It is also the case that states intervene - taking children into public care; prosecuting parents who fail to ensure their children attend school; and establishing both formal and informal norms about "care." But in all these respects, the private-personal realm remains elusive and unpredictable - because it is governed by logics other than those of the legal-contractual public realm. I do not mean this to be a romanticized contrast between "cold" logics of the public realm and the "warm" logics of the private or personal realm. The relations and practices of this informal welfare are often strained, contradictory and freighted with appalling emotional weight - and the private sphere is intimately bound up with forms of abuse and violence. So the fact that it (partially) escapes scrutiny, regulation and intervention by public authorities is - at best - a mixed blessing.

However, the issue of this site of welfare practices is significant in at least three ways. First, it troubles conceptual distinctions between public and private, and the concept of a mixed economy of welfare. In particular, it challenges "sectoral" models of the social organization of welfare and economizing understandings of welfare as an object to be produced, delivered and consumed. Second, the family-household-domestic realm is increasingly valorized by governmental policies that seek to displace varieties of welfare responsibility away from the state. In the process, the realm of the personal and the private has become increasingly responsibilized - in choice policies, in ideas of independence and self-sufficiency, and in the growing interest in the "co-production" of welfare outcomes. Third, in this valorization of the familyhousehold-domestic realm, governmental policies systematically represent this as the place (and work) of the family (even if they acknowledge varieties of family form). This discursive familialization of welfare normalizes the transfer of responsibility from public to private settings by evoking the "natural" bonds of affection, obligation and future-oriented investment (e.g., in children).

Out of this field of changing relationships, there are two questions about the state and its changing relationships to welfare that command particular attention. The first concerns the changing form of states: are we seeing the 
diminution of the state, its disaggregation or the dispersal of state power through other agents and agencies? In part, answers to this question depend on whether one takes an institutionalist view of the state or considers it through a relational perspective. Many have argued about the end of the state - in both its welfare state and nation-state forms, taking the shrinking (or contracting, Harden, 1992) trajectory of the state as the dominant, if not irreversible tendency. The "disaggregation" thesis is argued by Slaughter (2004) and is linked to the rise of "private authority" (Hansen and SalskovIversen, 2007). It perhaps relies too heavily on an image of an integrated or monolithic state as the previously prevailing state form. "Dispersal" is discussed in Clarke and Newman (1997) in the context of managerialism, but stresses the recomposition of both the sites and forms of state power by drawing other agents and agencies into the work of the state. I do not intend to try to resolve this issue here, but want to stress the importance of attending to the shifting forms of state organization and the field of relationships in which states are articulated, rather than reifying the idea of the state and equating it with one geographical/historical form (the European nation-state "constellation," as Leibfried and Zürn, 2005, call it).

The second major issue concerns the remaking of the relationship between the state and the nation in changing transnational conditions (Gupta and Sharma, 2006). This is certainly a critical issue in studying states, and one that is increasingly widely recognized. But there is an unfortunate temptation to mistake a historical phenomenon - the current visibility and salience of transnational relations and processes - for a conceptual one: that states now need to be understood transnationally, where previously they were indeed closed national systems. We might think more carefully about the history of forms of open-ness and patterns of interrelationship on the one hand, and forms of closure and models of integration on the other that have characterized nation-states. At the most general level, European nation-states have been constituted through the effort to create a nation out of contradictory, diverse and sometimes conflicting, conditions, including their colonial fields. Colonies provided the economic resources for capital accumulation and economic development; they provided populations on whom to practice innovative modes of governance; and they provided (some of) the others against whom the (racialized) "national" identity could be defined and elaborated. I want to insist on the importance of locating the trajectories of nation-states in changing transnational conditions and processes, rather than see them as moving from a national to a "post-national" form (or merely staying national). In the process, we might come to see specific nation-states as temporary constructed achievements (see the fuller discussion in Clarke, 2005). 
For me, states are simultaneously objects of political struggle and condensates of the balance of social forces. They are marked-scarred, evenby previous struggles: their apparatuses carry the traces of those struggles even as they are being transformed by new political projects and governmental programs. They are relationally constituted even as they are imagined as a separate agency and power standing over society (Gupta and Ferguson, 1992). They are profoundly contradictory - in their constitution, in their composition and in their effects.

\section{And Nation?}

Welfare state studies have been dominated by "methodological nationalism" - in both individual country studies and comparative approaches. In keeping with the imagery of the nation-state discussed above, this methodological approach assumed that welfare states were to be studied with the framework of separate nation-states, each of which provided a container enclosing its own welfare states. This container conception of the nationstate saw a people, united in a culture, occupying a clearly defined space, whose collective identity was expressed in a national politics, working through national institutions that delivered collective security and progress to the people of the nation. Instead of this organic and expressive unity, we can now think of the institutionalization of welfare, state and nation as a constructed unity: as an assemblage that presented itself as natural and normal, and as the highest point of social development (Leibfried and Zürn, 2005). In the unsettled world of contemporary globalization, the solidity of the national (as space, as way of life, as sovereignty) cannot be taken for granted. The traces of this disturbance can be seen in discussions of the shift from closed to open economies; the relationships between national, regional and global governance; the forms of mobility and migration; and the proliferation of nations and states, as new or revived collective identities lay claim to places. One way of reading these changes is that globalization has changed the world from one in which organic nation-state/welfare state formations existed, to one in which they have become destabilized. Such an analysis makes possible, and even risks legitimating, a certain political-cultural nostalgia. But we can think of the nation differently. Eley and Suny (1996) argue that nations should be seen as the outcome, rather than the basis, of "nation building" projects that lay claim to spaces, defining their boundaries and what they contain, and attempting to "nationalize" them.

The "nation" occupies a double role in relation to welfare states, drawing on a distinction between peoples and populations developed by Partha Chatterjee (2003). First, nation appears in the guise of the people - the nation as 
an imagined unity, bonded by a shared place and a common culture (tradition, way of life, etc.). This national character is then understood as infusing the public institutions of the society. At the same time, the nation also appears as a population (in Foucault's sense) - the imaginary aggregation of differences that are seen to matter. Despite its apparent "naturalness," such socio-demographic categorization is a contested mapping of differencemaking visible certain distinctions (and concealing others); making them available (or not) for public calculation and intervention); and often producing a plan for their improvement or perfectibility. In passing, it might be noted that populations are typically "imperfect," requiring interventions to improve them.

In sum, we might think of welfare states as articulated formations in which conceptions of welfare, state and nation are assembled in a more or less stable, institutionalized form. There is much more to say about such articulated formations, but in this context I want to concentrate on the conditions and consequences of these formations becoming unsettled and disarticulated - the ways in which welfare states are becoming transformed and reformed. A view of them as something more than singular objects opens up questions of the different forces, tendencies and pressures that play around each of the terms - welfare, state and nation. In the process, we may see more - and more divergent - tendencies at work in the re-making of welfare states. Welfare is the focus of conflicting projects - to reduce or retrench it; to make it "active;" to shift responsibilities; to expand its range (of provision and of those who have access to it). Similarly, states have been the focus of divergent political projects and claims: from 'roll back' to expanded capacities; from multi-level governance to the new public management; from marketization to enhanced technologies of democratic and participatory engagement. A singular or unilinear conception of the transformation of states and their state-ness risks missing the complex and contradictory politics of state remaking. Finally, nation has also become unsettled and the focus of competing imaginaries - in which nationalized traditions encounter transnational multi-culturalisms.

\section{Reassembling Welfare, State and Nation}

I have tried to argue that what we call "welfare states" are articulated formations of welfare, state and nation, which in specific national settings have taken particular forms. It is not just "welfare" that changes between welfare states, but so does the form of state organization (and its relationship with 
other institutions), and so too does the imagined nation-the people/population that welfare is intended to support, develop or bring into being. When studying "welfare state" change, we need to be attentive to both how each of these elements might be changing, and how their combination is being reconstructed. It is clear that such a view makes comparison harder-certainly harder than tracing how welfare states differ along a single axis, such as patterns of social protection spending. But it might get closer to what is going on with welfare states, particularly in a period where the politics of antiwelfarism and anti-statism have been dominant in Anglophone countries, where there is a widespread enthusiasm for going "beyond the state," and an interest in promoting societies of entrepreneurial individuals and responsible families.

The reform, re-making or reconstruction of welfare states is rarely a simple or singular process. Attempts to create/support an entrepreneurial individualist population may sit uncomfortably with existing commitments to an increasing elderly population. Attempts to move services "beyond the state" may generate increasing costs of processes of performance management, evaluation, surveillance and audit as problems of governing at a distance are discovered. In almost all of these reforms, images of the past, present and future of the nation (and who is included or excluded) are at stake - and often fiercely contested. These make the assemblages or ensembles that currently strive to "govern the social" ill-fitting, tension-filled and often contradictory formations. We should not look for, or at least, we should not expect to find, coherent, uniform and non-contradictory systems of doing welfare.

In the end, it may be more productive to see the dynamics of "welfare reform" as a set of processes that seek to create-and institutionalize- new mappings of the social, carried through political and governmental projects. This remaking of the social extends well beyond its articulation with the economic, involving new assemblages of people, positions and practices. Such changes require the reconstruction of ways of life, the elaboration of sets of distinctions and relations within a population, and the inculcation of habits and practices that fit with dominant conceptions of a "modern people" taking their place in a global world. Such projects also require "modern" ways of governing to sustain them. These are the stakes of contemporary efforts to reassemble welfare, state and nation.

\section{References}

Castles F (2004) The Future of the Welfare State: Crisis Myths and Crisis Realities. Oxford: Oxford University Press.

Chatterjee P (2003) The Politics of the Governed. New York: Columbia University Press. 
Christie N (1996) Crime and Civilisation. New Internationalist 282: 10-12.

Clarke J (2005) Welfare States as Nation States: Some Conceptual Reflections. Social Policy and Society 4 (4): 407-415.

Clarke J (2007) Subordinating the Social? Neoliberalism and the Remaking of Welfare Capitalism. Cultural Studies 21 (6): 974-987.

Clarke J (2008) Reconstructing Nation, State and Welfare: The Transformation of Welfare States. In: Seelieb-Kaiser M (ed.) Welfare State Transformations: Comparative Perspectives. Basingstoke: Palgrave Macmillan, 197-209.

Clasen J (2007) Comparative Social Policy-Old Questions, New Topics and Original Answers. Government and Opposition 42 (2): 250-257.

Clasen J and Siegel NA (eds) (2008) Investigating Welfare State Change-the Dependent Variable Problem in Comparative Analysis. Northhampton, MA: Edward Elgar.

Cook D (2006) Criminal and Social Justice. London: Sage Publications.

Daly M (2000) The Gender Division of Welfare. Cambridge: Cambridge University Press.

Eley G and Suny R (eds) (1996) Becoming National: A Reader. Oxford: Oxford University Press.

Ellison N (2006) The Transformation of Welfare States? London: Routledge.

Farnsworth K (2012) Social versus Corporate Welfare: Competing Needs and Interests within the Welfare State. Basingstoke: Palgrave Macmillan.

Friedman M and Freidman R (1984) The Tyranny of the Status Quo. Orlando, Fla: Harcourt Brace Jovanovich.

Gould J (ed.) (2005) The New Conditionality: The Politics of Poverty Reduction Strategies. London: Zed Books.

Gupta A and Ferguson J (1992) Beyond "Culture": Space, Identity and the Politics of Difference. Cultural Anthropology 7 (1): 6-23.

Hansen HK and Salskov-Iversen D (eds) (2007) Critical Perspectives on Private Authority in Global Politics. Basingstoke: Palgrave Macmillan.

Harden I (1992) The Contracting State. Buckingham: Open University Press.

Hartmann Y (2005) In Bed with the Enemy: Some Ideas on the Connections between Neoliberalism and the Welfare State. Current Sociology 53 (1): 57-73.

Johnson N (ed) (1996) Mixed Economies of Welfare. Hemel Hempstead: Harvester Wheatsheaf.

Jones C and Novak T (1999) Poverty, Welfare and the Disciplinary State. London: Routledge.

Kuhnle S (ed) (2000) Survival of the European Welfare State. London: Routledge.

Leibfried S and Zürn M (2005) Reconfiguring the National Constellation. In: Leibfried S and Zürn M (eds) Transformations of the State. Cambridge: Cambridge University Press, 1-36.

Lewis G (2000) Introduction: Expanding the Social Policy Imaginary. In: Lewis G, Gewirtz S and Clarke J (eds) Rethinking Social Policy. London: Sage Publications/The Open University.

Lewis G, Gewirtz S and Clarke J (eds) (2000) Rethinking Social Policy. London: Sage Publications/The Open University.

Morley M and Petras J (1998) Wealth and Poverty in the National Economy: The Domestic Foundations of Clinton's Global Policy.' In: Lo C and Schwartz M (eds) Social Policy and the Conservative Agenda. Oxford: Blackwell.

Newman J and Clarke J (2009) Publics, Politics and Power: Remaking the Public in Public Services. London: Sage Publications.

Peck J (2001) Workfare States. New York: Guilford Press. 
Petersen A, Barns I, Dudley J and Harris P (1999) Post-structuralism, Citizenship and Social Policy. London: Routledge.

Pierson C (1991) Beyond the Welfare State? Cambridge: Polity.

Rao N (1996) Towards Welfare Pluralism: Public Services in a Time of Change. Aldershot: Dartmouth Publishing Company.

Rose, N (1996) The Death of the Social? Re-figuring the Territory of Government. Economy and Society, 25 (3): 327-356.

Seeleib-Kaiser M (ed.) (2008) Welfare State Transformations. Basingstoke: Palgrave Macmillan.

Sharma A and Gupta A (2006) Rethinking Theories of the State in an Age of Globalization. In: Sharma A and Gupta A (eds) The Anthropology of the State: A Reader. Oxford: Blackwell Publishing: 1-42.

Slaughter A (2004) A New World Order. Princeton, NJ: Princeton University Press.

Somers M (2008) Genealogies of Citizenship: Markets, Statelessness and the Right to Have Rights. Cambridge: Cambridge University Press.

Sykes R (1998) Studying European Social Policy-Issue and Perspectives. In: Sykes R and Alcock P (eds) Developments in European Social Policy: Convergence and Diversity. Bristol: The Policy Press.

Veit-Wilson J (2000) States of Welfare: A Conceptual Challenge. Social Policy and Administration 34 (1): 1-25.

Wacquant L (2009) Punishing the Poor: The Neo-liberal Government of Social Insecurity. Durham, NC: Duke University Press.

Williams R (1976) Keywords: A Vocabulary of Culture and Society. London: Fontana. 


\section{Comparative Analyses of Western Welfare State Settings}





\section{Sigrid Leitner}

\section{Varieties of Familialism: Developing Care Policies in Conservative Welfare States ${ }^{1}$}

\section{Introduction: What is Familialism?}

The concept of familialism was developed in the context of international comparative welfare state and family policy research (see Leitner, 2006). It focuses on the family - or, more broadly defined, on private households - as an important resource of welfare production and emphasizes the role and function of the family, especially of familial care, for the social security system. In fact, the care of children, the elderly, and the disabled is mostly provided free of charge by close, usually female relatives in private homes - and welfare states tend to rely on these resources, although to different degrees. Some welfare states explicitly attempt to increase care responsibilities among family members, others relieve families from care responsibilities, and several regimes do not intervene at all or apply a mixed strategy. Esping-Andersen (1999: 51) distinguishes between familialistic and de-familializing welfare regimes:

A familialistic system [...] is one in which public policy assumes-indeed insists - that households must carry the principal responsibility for their members' welfare. A de-familializing regime is one which seeks to unburden the household and diminish individuals' welfare dependence on kinship.

Welfare state policies are therefore able to act in a familializing or defamilializing way. Accordingly, we need to identify those social policy measures that attach more and those that attach less importance to the family as the place of welfare production. In the following, I briefly outline some theoretical considerations around familializing and de-familializing social policy measures and different types of familialism. I then classify the three well-known types of welfare regimes named by Esping-Andersen (1996) according to the typology of familialism. My focus is on conservative welfare states and their historical development of child care and elder care policies. I ask not only whether and how such policies arose, but also how these changes can be explained.

1 This article summarizes the main findings of my habilitation project. 


\section{Theoretical Foundations of the Concept ${ }^{2}$}

In the concept of familialism, a distinction is made between familializing and de-familializing instruments of social policy. What is the impact of these two analytical categories, and what are the expected effects on the caring function of the family? The following sections address this question, and then set out a typology of familialism.

\subsection{De-familializing Social Policy}

Social services can be classified as mainly de-familializing instruments because they socialize or "marketize" the caring responsibilities of the family. However, in order to evaluate the de-familializing effects of social services it is important to consider how extensively services are used and what kind of service is provided. Care facilities such as private child minders, preschools, kindergartens, and afterschool care constitute the core of possible child care provision. Besides education, they aim to reconcile the needs of family and employment, hence to de-familialize parents. Overall, the de-familializing effect of child care provision depends on how well the provider meets this goal of compatibility: long and flexible opening hours, easy access to care facilities (high supply and low costs), and a high quality of care provision, for example, would be indicators of a high degree of de-familialization.

Ambulatory social services and partially or fully residential care facilities form the core of elder care provision. They certainly contribute to relieving families, as they reduce the amount of care the family has to afford by itself. At the same time, however, they can also contribute to the maintenance of a predominantly familial care arrangement ("crowding in"), in which case their de-familializing effects are rather weak. A high degree of de-familializing would only obtain if a family were effectively unburdened of the main responsibility for care. This is the case in residential or partially residential care facilities or when a dense network of ambulatory care services exists, allowing people in need of care to live largely independently of familial care.

\subsection{Familializing Social Policy}

In contrast, there are familializing policies that actively support the family in providing care: time rights and cash rights for familial care work. Time rights, such as parental leave or care leave, aim to provide legally regulated periods of leave during which employed people are able to fulfill their care

This section draws on Leitner (2011: 86-88). 
responsibilities. They have a familializing effect, supporting temporary care by the family. Their familializing effects become stronger the longer the time periods defined, especially because long periods of leave from employment have a negative influence on reintegration into the labor market. In this context, part-time employment constitutes a special case. On the one hand, it offers an alternative to full-time employment, and the reduction of work hours can be used for familial care. It is only in this way that part-time work has a familializing effect. On the other hand, part-time work can also be an alternative to non-employment for familial carers: if the amount of familial care responsibility allows part-time employment-for example in combination with the use of social services - then part-time employment does encourage labor market participation, but does not automatically have a de-familializing effect. De-familializing effects arise, if at all, only indirectly, through the outsourcing of the care of a family member to social services.

Familial care may be supported by various cash benefits. These include indirect transfer payments to family members-for example the survivor's pension or free membership of the spouse's health insurance plan-and individualized transfers such as parental leave benefits or care leave benefits. The increase in the familial carers' income through these direct and indirect transfers results in direct support for familial care work and the empowerment of familial carers. The transfers offer an alternative to securing the family's income through paid employment, and can therefore be classified as an incentive for care by the family. The higher the transfer payments, the more comprehensively they enable the "right to time to care" (Knijn and Kremer, 1997) and the stronger are their familializing effects.

\subsection{Four Types of Familialism}

Assuming that welfare regimes contain both familializing and de-familializing policies, and that each of these has either a weak or a strong expression, a four-field matrix emerges. This matrix allows us to distinguish between four ideal types of familialism (Table 1$):^{3}$

Table 1: Four types of familialism

\begin{tabular}{|l|l|l|}
\hline \multirow{3}{*}{$\begin{array}{l}\text { Familialization } \\
\text { Weak }\end{array}$} & \multicolumn{2}{|c|}{ Strong } \\
\cline { 2 - 3 } & Optional familialism & Explicit familialism \\
\cline { 2 - 3 } & De-familialism & Implicit familialism \\
\hline
\end{tabular}

Source: Leitner, 2003

3 This typology is theoretized, and also empirically tested for the first time, in Leitner (2003). 
Explicit familialism supports the family in caring for children, the disabled, and the elderly by means of familialistic policies. At the same time it lacks de-familializing policies. Familial care is thus not only encouraged, but explicitly enforced through the lack of any alternative to care by family members.

Within optional familialism there are both familializing and defamilializing policies. The caring family is strengthened, but also given the option of receiving partial relief from caring responsibilities. In both explicit and optional familialism, the "right to time for care" is honored by familialistic policies that enable the family to care. Only in optional familialism, however, is the family's right to care not equated with the family's obligation to care.

Implicit familialism offers neither de-familializing nor familializing policies. Nevertheless, the family is - ex negativo, so to speak - the primary caregiver in these welfare regimes, since there are no alternatives at hand. This type implicitly relies on the family with respect to care issues. It might also be called "familialism by default."

Finally, de-familialism - or anti-familialism - is characterized by strong de-familialization due to the state or market provision of care services along with weak familialization. Thus, familial carers are unburdened fully or in part, but the family's right to care is not honored.

\section{Welfare Regimes and Types of Familialism}

An analysis of different types of familialism might be most interesting for the case of the conservative welfare states, because these accord special importance to child care and elder care within the family and are thus prototypical familialistic welfare regimes. One of the main foundations of a conservative welfare regime is the gender division of labor institutionalized through the "strong" male-breadwinner model (Ostner, 1995). This model guarantees that within a heterosexual couple one partner is available for the care of young, disabled, or frail family members while the other partner is gainfully employed and secures the family's income. In combination with the principle of subsidiarity, which defines social service provision as first and foremost the duty of the family, a division of labor between the state and women emerges (Kulawik, 1989: 246). On the one hand, women are enabled to remain in a state of "pre-commodification": the male breadwinner and his social security protection give women the opportunity not to participate in the labor market in order to care for family members. On the other, unpaid care 
of the family by women secures the functioning of the "service-lean" conservative welfare regime.

Conservative welfare states that provide cash transfers or time rights for care can be characterized as explicit familialistic regimes, while conservative welfare states that have no familializing policies are implicit familialistic regimes. The former access care by offering positive incentives for families to bear the responsibility of care. The latter assume that the family will take on care responsibility as a matter of course (Figure 1).

Figure 1: Classification of welfare regimes according to the types of familialism

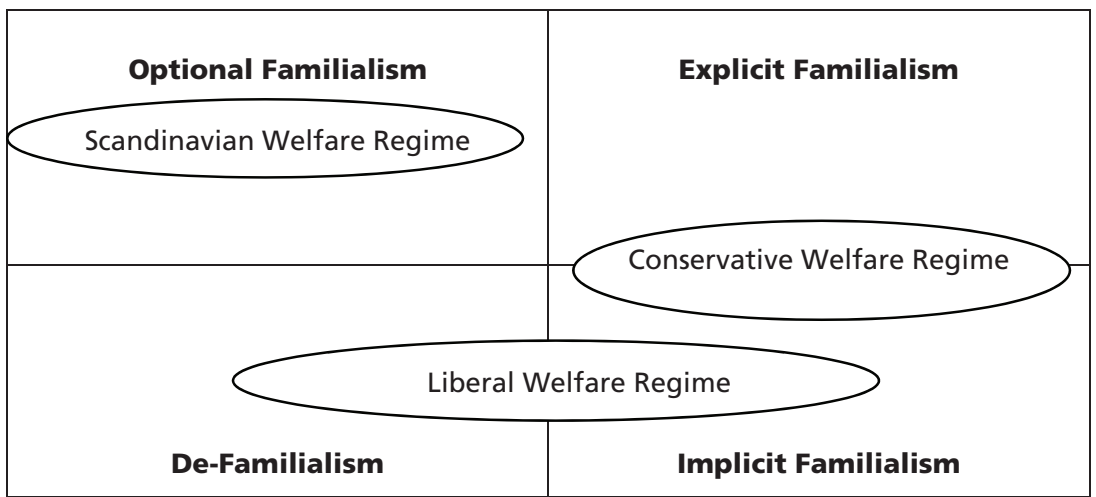

Scandinavian welfare states, as opposed to the conservative welfare states described above, fall into the category of optional familialism. Gender egalitarianism (whether actual or only desired) leads to a high level of direct transfer payments for familial care and to an adequate level of de-familializing structures. Liberal welfare states, on the other hand, pursue implicit familialism and only offer transfer payments for familial care in cases of impending poverty; existing attitudes to gender roles remain unchallenged. Although the liberal welfare state could alternatively be associated with de-familialization, this would be a market-driven process, with the corresponding consequences for social inequality.

The following section examines the historical development of familialism in four conservative welfare state settings: Belgium, Germany, France, and Austria. These four countries have in common that, over time, they have gone through various forms of familialism within both child care and elder care. The "critical junctures" (Collier and Collier, 1991), the crucial timing of the changes, will be identified and explanations offered. 


\section{Child care Policies in Conservative Welfare States}

In conservative welfare states, two paths of development towards familialism in child care policies can be identified. For one of these paths, there is a similarity in the development of policies in Austria and Germany. Both these countries originally applied implicit familialism, followed by a phase of explicit familialism (starting in the 1930s) in which only indirect cash benefits, such as free co-membership of the statutory health insurance plan, survivor's pensions, or tax reductions for single-income families, were available. During the second phase of explicit familialism, these structures were supplemented by direct structures, namely parental leave and subsidies for new parents. This development started in Austria in 1957 and in Germany in 1977. The transition to explicit familialism is in particular need of explanation, as is the trend in Germany to abandon the conservative path in favor of optional familialism, which has become more apparent through the increase in child care facilities since 2005 and the introduction of compensation for lost income during parental leave, the "parental money" or Elterngeld, in 2007.

Regarding the second path, the development of familialism in France resembles that in Belgium. Both countries saw the introduction of a form of defamilialization in the late nineteenth century. By the early-1970s, as the low employment rate of mothers in that period shows, these measures were used more for the education of preschool children than for the task of reconciling work with family life. To that extent, this phase of development could be described as an implicit familialism constructed by the culture itself. In both countries, this was later replaced by explicit familialism, but whereas Belgium developed only indirect strategies, France adopted both indirect and direct instruments of familialism. In the $1980 \mathrm{~s}$, both countries then moved towards an optional familialism whereby welfare policy could build on the child care structures already established during the period of de-familialization, while also adopting new measures.

The introduction of directly familializing structures during the mid-1980s, and the parallel expansion of child care options towards an optional familialism, in this second version of the development of familialism within conservative welfare states also deserves explanation.

\section{Aside: Conservative Optional Familialism}

Contrary to earlier categorizations of welfare states within the typology of familialism, empirical analysis has shown that conservative welfare states are 
not simply either implicitly or explicitly familial: they can also be optionally familial. The specificity of optional familialism in conservative welfare states is that it features socioeconomic differentiations, in line with the statusreproducing nature of this type of welfare state. Whereas optional familialism with a social democratic character offers high-quality, egalitarian benefits, the nature of conservative welfare states means that parents' freedom of choice (between caring for their children themselves or using external carers) exists only for those who have the necessary monetary resources. This is especially true in France and Belgium, though in Germany, too, freedom of choice is available only if the income to be compensated is high enough. Moreover, France demonstrates a socioeconomic bias within its child care options, one that can also be seen in Belgium: the tax benefits for using a child minder or nanny create extra options only for those in a middle to high income bracket.

The specific attributes of conservative optional familialism also emerge in the gender-discriminatory arrangement of its familializing structures. In France and Belgium, the new parents' subsidy is not high enough to cover living costs, leading to a gender skew in its adoption. In Germany, the gender skew arises from the income-dependent nature of the subsidy, which means that the incentive to share at-home child care is higher for those with better incomes. Contrary to this, the optional familialism of the social democratic model would ideally provide familializing cash benefits that covered the costs of living for all income brackets.

The conservative welfare states' move towards optional familialism should therefore not be seen as a move towards the social democratic model, but rather as another form of conservative welfare states, since there is a conservative version of optional familialism.

\section{Explaining Change in Child care Policies}

This section outlines the introduction of directly familialistic measures in Germany and Austria and the change from explicit to optional familialism in France, Belgium, and Germany. I argue that the changes in child care policy in Germany, Austria, France, and Belgium can largely be seen as a response to rising employment (or at least desire for employment) among women, especially young women, in all these countries. I also add some other major factors to my explanatory model to do justice to this multifaceted picture. 


\subsection{The Introduction of Paid Child care Leave in Austria and Germany}

The difficulties that mothers in Austria and Germany face in combining work and child care were a major factor in the introduction of paid parental leave. For both countries, in other words, the rising employment rate of young women can be identified as the generator of this development. Despite a similarly low level of female employment, Austria was quicker than Germany to identify the incompatibility of work and parenting as a social problem and a political issue.

In the late 1980s, both the leading Austrian political parties agreed that women should not work during the first months after giving birth. Whereas the Social Democrats saw this maternity leave as an incentive for women to return to work within a three-phase model (initial employment, child-care break, reentry to employment), the Christian Democrats saw it as a motivation for mothers to leave work permanently and rely on the traditional malebreadwinner model. As a result of these ideological differences between the two parties and the compromise-based nature of the Austrian political system, the new familializing legislation included concessions on both sides. At this time, de-familialism was avoided, being deemed too radical. In the end, the social policy that was institutionalized was a modernized breadwinner model. Until 1990, mothers were entitled to one year of parental leave. The period was generally extended to three years, however, because the dearth of child care options precluded an earlier return to work. Even then, the half-day pattern of kindergarten availability meant that mothers were only able to return to work part-time. The later extension of official parental leave to two years and the option to include fathers changed little with regard to the threephase model of female employment (Neyer, 1996).

The new regulations introducing a universal child care cash benefit in 2002 extended the paid leave of absence once again, while at the same time fostering the practice of mothers working in positions with fewer weekly hours. It is therefore still the case that previously employed mothers become dependent on a breadwinner once they have a child, and that their opportunities to contribute financially to the household dwindle as they take up parttime jobs or positions with low weekly hours. In addition, previously nonemployed parents are now entitled to claim the benefit, which encourages familial child care as a sole occupation. This change can be attributed to the loss of political power for the Social Democrats (Leitner, 2010).

In Germany, the Social Democrats were the first to respond to the problems of reconciling work and family life, in 1979, followed by the Christian Democrats in 1985. Similarly to the Austrian case, the two parties were di- 
vided by fundamental ideological differences. Whereas the Social Democrats wanted to enable mothers to enter employment and allow parents to choose between caring for their children themselves or organizing external care, the Christian Democrats saw employment and motherhood as incompatible. With the change of government in 1982, the Social Democrat maternity leave, which allowed employed mothers to take a leave of absence, was replaced by Christian Democrat subsidies for new parents. This embedded the compatibility of motherhood and work in the framework of a three-phase model, and generally endorsed the familial care of children. Unlike in Austria, the result was the institutionalization of an only partially modernized breadwinner model. Under the maxim of freedom of choice, even mothers who had not worked before the birth of their child were supported (Kolbe, 2002). In Austria, this dual target group was not established until 2002.

The above shows that the transition to directly explicit familialism was induced by increased female employment and the resulting problems around combining work with child care. In both countries there were ideological differences between Christian Democrats and Social Democrats. In Austria, this led to a modernized breadwinner model due to the forces of coalition and negotiation, while in Germany the Christian Democrat government's power was sufficient to establish an only partly modernized breadwinner model. In both cases, it is noteworthy that not only the Social Democrats but also the Christian Democrats accepted the employment of mothers in the form of a three-phase model. This indicates a new perception of women that was previously not detectable.

\subsection{The Diversification of Child care in France and Belgium}

The motivation for extending child care options in France and Belgium was also the increase in female employment and the resulting compatibility problems. Unlike in Austria and Germany, however, the introduction of directly familializing measures was not the initial goal. Rather, the aim was to extend de-familializing child care structures. France and Belgium were able to build on an existing tradition of "écoles maternelles" for preschool children of twoand-a-half to six years of age. This demonstrates the importance of the political legacy of the late-nineteenth-century argument on who should have sovereignty over childrearing (Morgan and Zippel, 2003). Preschools in France are part of the state education system, which is meant to be open to all children. The compatibility problem increased the demand for places within that system, and had to be satisfied if only for egalitarian reasons. In Belgium, on the other hand, competition between different educational systems had led to a patchwork of preschools, which over time were increasingly used to im- 
prove the compatibility of work and family life. This tradition of external childrearing provision meant that France and Belgium had a head start over the conservative welfare states with regard to de-familializing measures. This became apparent during the expansion of care for under-three-year-olds. The fact that since the late nineteenth century children had spent a great deal of time in preschool facilities rather than with their parents made cultural acceptance of family-external care for the under threes much easier.

The secularized Christian Democrats introduced an increase in child care places in the 1970s with the aim of counteracting the labor shortage by increasing female employment. The Socialists wanted to continue this increase in child care places in the 1980s in order to fulfill the demands for equality put forward by the women's liberation movement. However, they were not able to carry out this enterprise, mainly for financial reasons. As an alternative, since the mid-1980s there has been a diversification in forms of child care. This is mainly driven by employment-market considerations, being intended to help fight the high unemployment rate. It includes support for nannies and child minders to improve the child care situation and the introduction of directly familializing measures to increase familial child care by mothers who leave work to stay at home with their children (Fagnani, 2000). In this respect, France is offering the same socioeconomically differentiated and gender-discriminatory choice as the conservative variety of optional familialism.

In Belgium, the increase in child care by child minders was implemented for financial reasons as early as the 1970s. The national family fund for employers, a response to the compatibility problems of a mainly female clientele, was an important political lobby and a considerable motor for this development.

Directly familializing measures were introduced in both Belgium and France in the mid-1980s, and were motivated mainly by employment market issues. Mothers were offered a successive - as opposed to simultaneousmodel of compatibility in order to take pressure off the employment market (Marques-Pereira and Paye, 1998).

For both countries, the transition to the conservative version of optional familialism was connected with two developments: firstly working mothers' increasing reconciliation problems, and secondly the increasing importance of economic arguments in political problem-solving. The two countries have had similar reasons for their conservative familialistic solution to the reconciliation problem: the development of familialism was determined by the political legacy of preschools, the tight financial situation, and the functionalization of child care for employment-market goals. 


\subsection{Germany: From Explicit to Optional Familialism}

Germany's transition to optional familialism is still at a fledgling stage. This is especially worthy of attention since (1) Germany, unlike France and Belgium, does not have the political inheritance of a child care infrastructure that could be built upon, and (2) for the first time a conservative welfare state is guaranteeing independence from a breadwinner income for once highearning parents by introducing Elterngeld, the compensation of lost income.

The German reform policies are a reaction to the falling birth rate and the predicted future labor shortage. By expanding child care for under-threeyear-olds, the compatibility of family life and employment is to be improved in order to increase the female employment rate in the medium term. In the long term, in combination with Elterngeld this expansion is intended to lead to a higher birth rate, especially among higher-income (and better educated) groups, and thus to a higher workforce volume. The early care of children outside the family also, through appropriate adaptation to children's developmental needs, has the potential to increase the quality of the future workforce. This productivist paradigm of family policy is shared by both Social Democrats and Christian Democrats, and competes with the traditional view of women and family that is still quite widely held within the Christian Democrat party (Leitner, 2008).

\section{Elder care Policies in Conservative Welfare States: Changes and Explanations}

The patterns of development within elder care are similar in all four countries. Not unlike child care policies, the first step was the move from implicit to indirectly explicit familialism, with familializing measures introduced comparatively early in Belgium and Austria. In Austria and in Germany, directly familializing measures were then introduced in the 1990s, whereas in Belgium familializing structures within employment policies had been put in place during the 1980s, and France had already provided cash benefits for the care of the disabled by family members as a part of its disability policies since the 1970s. In the area of elder care policies, the progression from indirectly to directly explicit familialism is particularly interesting.

In three of the countries discussed here, the transition from indirectly to directly explicit familialism within elder care happened because of social structural transformation processes - specifically, increasingly aging societies and the increase in female employment - and the resulting costs for social policy. Belgium is the only one of the four where the predicted deficit in future provi- 
sion of care by family members played no role in the introduction of directly familializing measures.

In both Austria and Germany, specific "advocacy coalitions" were the most significant motivators for this policy development. In Austria, the Green Party and the "Zivilinvalidenverband," an organization advocating for the rights of the disabled, put pressure on the government. In Germany, it was the municipalities and states that joined forces with welfare organizations and pushed for action to counteract mounting costs in the care sector. Both countries also introduced their care allowances as an incentive for care to be performed by family members. For financial, cultural, and moral reasons, it was the concept of familial care that determined the organization of these benefits (Behning, 1999).

The first directly familializing measures were introduced in France quite early, in the mid-1970s, in the framework of disability policies. The main consideration was to give those needing care autonomy by means of the benefits provided. Over time, the benefits originally directed at disabled people were taken up by an increasing number of elderly people in need of care, overwhelming the municipalities, which were financing this care out of their social welfare budgets. The number of elderly people in need of care became a serious financial problem for the public authorities, and forced the politicians to act. The answer they found was the introduction of an "allocation personalisée d'autonomie" (APA) in 2002, which basically continued the previous policy by new means. The benefit remained income-dependent and recipients had to prove that they used it to pay for care. In this case, we can identify a clear continuity in social policy, probably as a result of path dependency. Unlike in the other three countries, in France the question of care by family members has played only a marginal role. There is an unspoken assumption that morality alone will motivate the closest relatives or partners to take on the role of caring even without external motivations. The goal of the APA was less to assist caregiving relatives than to increase employment in the sector of social service provision. The economic gain to be expected from this measure was therefore one important political legitimization for the policy (Holdenrieder, 2003).

In Belgium, in contrast, the transition to directly explicit familialism in elder care policies was reached via the detour of employment-market policies. The introduction of a paid leave of absence for carers was mainly motivated by the politics of unemployment: employed caring relatives who take advantage of this leave of absence relieve pressure on the employmentmarket. 


\section{Conclusions}

The historical development of familialism differed for child care and elder care policies in the four conservative welfare states I have discussed. In child care, Austria and Germany moved from implicit familialism to indirectly, then directly explicit familialism. Belgium and France moved from defamilialization (culturally implicit familialism), via indirect and direct forms of explicit familialism, to optional familialism. Germany is now on the way to optional familialism. It is important to mention the special character of conservative optional familialism: it reproduces social status at the point of choice between home-based care and external care and between the different forms of external care.

In elder care policies, all four countries progressed in a similar way from implicit familialism to indirectly and later to directly explicit familialism. Only the timing of this development differed.

On a more abstract level, several theories can be applied to explain these changes in child care and elder care policies in Austria, Belgium, France, and Germany:

- Factors that reflect the societal structure, such as increased female employment and the aging society, played a role in the transition to directly explicit familialism for both political fields, since the political pressure they generated ultimately led to political action.

- The economic frameworks were - albeit negatively - the main motivation for the transition to directly explicit familialism in elder care and to optional familialism in child care in France and Belgium.

- The development of familialism was influenced by the varying cultural frameworks in the four countries. The transition to directly explicit familialism in child care was triggered by a modern perception of women, while the transition to optional familialism in child care ultimately mirrored two competing models: the care of children within their family versus care by external parties. The overall model of care within the family also played an important part in the transition to explicit familialism in elder care in Austria and Germany.

- Political parties and their ideologies played a role in Germany and Austria in the transition to directly explicit familialism in child care, while in both countries theme-specific advocacy coalitions shaped the move towards familialism in elder care.

The political inheritance of the nineteenth century was a relevant factor in the transition to optional familialism in child care in Belgium and France. 
Overall, functionalist and interest- and conflict-theoretical approaches, culturally sensitive explanatory theories, and path dependency theories have all proven relevant in explaining individual timings and countries. However, a specifically "conservative" explanation for the change in familialism cannot be inferred from the empirical findings.

\section{References}

Behning U (1999) Zum Wandel der Geschlechterrepräsentationen in der Sozialpolitik. Ein policy-analytischer Vergleich der Politikprozesse zum österreichischen Bundespflegegeldgesetz und zum bundesdeutschen Pflege-Versicherungsgesetz. Opladen: Leske + Budrich.

Collier RB and Collier D (1991) Shaping the Political Arena: Critical Junctures, the Labor Movement, and Regime Dynamics in Latin America. Princeton: Princeton University Press.

Esping-Andersen G (1996) The Three Worlds of Welfare Capitalism. Cambridge: Polity Press.

Esping-Andersen G (1999) Social Foundations of Postindustrial Economies. Oxford: Oxford University Press.

Fagnani J (2000) Un travail et des enfants. Petits arbitrages et grands dilemmes. Paris: Bayard Éditions.

Holdenrieder J (2003) Comparative Evaluation of Long-term Care Policies for the Elderly in the EU. Frankfurt am Main: Peter Lang Verlag.

Knijn T and Kremer M (1997) Gender and the Caring Dimension of Welfare States: Toward Inclusive Citizenship. Social Politics 4 (3): 328-361.

Kolbe W (2002) Elternschaft im Wohlfahrtsstaat. Schweden und die Bundesrepublik im Vergleich. 1945-2000. Frankfurt am Main \& New York: Campus.

Kulawik T (1989) Auf unsicheren Wegen. Perspektiven der sozialen Sicherung von Frauen. In: Riedmüller B and Rodenstein M (eds) Wie sicher ist die soziale Sicherung? Frankfurt am Main: Suhrkamp, 241-265.

Leitner S (2003) Varieties of Familialism. The Caring Function of the Family in Comparative Perspective. European Societies 5 (4): 353-375.

Leitner S (2006) Familialism. In: Fitzpatrick T, Kwon HJ, Manning N, Midgley J, and Pascal G (eds) International Encyclopedia of Social Policy. London: Routledge, 447-449.

Leitner S (2008) Ökonomische Funktionalität der Familienpolitik oder familienpolitische Funktionalisierung der Ökonomie. In: Evers A and Heinze RG (eds) Sozialpolitik. Ökonomisierung und Entgrenzung. Wiesbaden: VS, 67-82.

Leitner S (2010) Germany Outpaces Austria: The Historical Contingencies of Conservative Progressivism in Family Policy. Journal of European Social Policy 20 (5): 456-467.

Leitner S (2011) Familialism in Germany, Italy and Switzerland: A Frame for Succession in Family Enterprises? In: Stamm I, Breitschmid P, and Kohli M (eds) Doing Succession in Europe. Generational Transfers in Family Businesses in Comparative Perspective. Opladen: Budrich UniPress, 85-97.

Marques-Pereira B and Paye O (1998) La Belgique. Vices et vertus du pragmatisme. In: Jenson J and Sineau M (eds) Qui doit garder le jeune enfant? Modes d'accueil et travail des mères dans l'Europe en crise. Paris: Librairie Générale de Droit et de Jurisprudence, 109-139. 
Morgan KJ and Zippel K (2003) Paid to Care: The Origins and Effects of Care Leave Policies in Western Europe. Social Politics 10 (1): 49-79.

Neyer G (1996) Karenzurlaub in Österreich. Zur sozialpolitischen Konstruktion geschlechtlicher Ungleichheit am Beispiel einer empirischen Analyse der Wirkungen von Mutterschutzleistungen in Österreich. PhD diss., University of Vienna.

Ostner I (1995) Arm ohne Ehemann? Sozialpolitische Regulierung von Lebenschancen für Frauen im internationalen Vergleich. Aus Politik und Zeitgeschichte 36/37: 3-12. 



\section{Jamie Peck and Nik Theodore}

\section{On the Global Frontier of Post-Welfare Policymaking: Conditional Cash Transfers as Fast Social Policy}

\section{Introduction: Globalizing Post-Welfare States}

The period since the declaration of the Millennium Development Goals ${ }^{1}$ has been marked by an unprecedented attempt to build, advance, and consolidate a new hegemonic front in the field of social-welfare policy. Conditional cash transfer (CCT) programs have been in the vanguard of this effort. CCTs provide modest cash payments only to those low-income households that "play by the rules," enrolling children in school, attending to domestic hygiene and appropriate healthcare, and building the human capital of the next generation. The CCT model encapsulates a new logic of social assistance quite different to the welfare-state rationalities of needs-based entitlement and universal coverage: it emphasizes socioeconomic promotion over social protection and long-term human-capital investment over temporary relief; it advances the principles of reciprocal obligation and "co-responsibility" over universal human rights or top-down forms of social responsibility; it privileges targeted interventions over generalized entitlements; and it inculcates active engagement over passive benefit receipt, an approach captured in the phrase often associated with these programs: "paying for good behavior."

Often styled as a Latin American "invention," the operational principles and programming practices of CCTs have been actively co-produced, almost since their inception, by multilateral development agencies like the World Bank. They have since spread throughout South America, and indeed to every continent, at a prolific rate. The "onward march of conditional cash transfer [programs]," Anthony Hall (2012: 26) has noted, "is an increasingly global phenomenon." In less than a decade, what began as a pair of isolated experiments (in Mexico and Brazil) has become established, in effect, as the default setting for anti-poverty reform: "the international development community has clearly defined CCTs as the new norm" (Sugiyama, 2011: 264).

But what Lawrence Aber and Laura Rawlings describe, writing for the World Bank, as the "remarkable global expansion" (Aber and Rawlings, 2011: 1) of CCTs has not been achieved by way of heavy-handed coercion;

1 See http://www.un.org/millenniumgoals/bkgd.shtml. 
these widely emulated programs have been subject to a distinctive form of best-practice contagion, fueled by expensively marshaled evaluation evidence and guided by expert networks: "CCTs have been closely studied and well evaluated, creating both a strong evidence base from which to inform policy decisions and an active global community of practice." Classically modeled on Progresa-Oportunidades in Mexico, CCTs are now found in approaching fifty countries. They have been trumpeted by the Economist (2010: 10) as "the world's favourite anti-poverty device," while for Nancy Birdsall, president of the Center for Global Development, they are "as close as you can come to a magic bullet" (quoted in Dugger, 2004: A1).

CCTs seek to be both pro-poor and pro-market by incentivizing those human-capital building behaviors, like regular school attendance and preventative healthcare, determined to benefit the children of low-income households. As such, they borrow concepts from behavioral economics and motivational psychology, melding these with the pragmatic, best-practice style characteristic of the "new" Washington Consensus, in service of building a post-welfare rationale for "safety net" spending. Conditioning cash transfers is the crucial maneuver here, for this transforms what might be seen as an ameliorative "hand out" into an instrumentalist "hand up," while enabling a form of social targeting actively linked to human-capital investment. According to the World Bank's logic, "by supporting minimum levels of consumption, helping credit-constrained poor people to be productive, and providing incentives for long-term investments in human capital, safety nets have a potentially important role in compensating for the market failures that help perpetuate poverty, particularly in high inequality settings" (Aber and Rawlings, 2011: 4).

The global CCT wave has been enabled, bankrolled, and steered by the World Bank and its allies in the multilateral community (in concert with a small army of policy entrepreneurs, consultants, evaluation scientists, and practitioner-advocates), both through established channels like policy-based lending and, no less consequentially, through the increasingly isomorphic fields of expert knowledge and technocratic practice. The World Bank, the Inter-American Development Bank (IABD), and other multilateral development agencies often underwrite the operating costs of CCT programs - this having become, in effect, their authorized mode of social-policy intervention-but they have also actively fostered an explicitly experimental ethos around these programs, supporting the deployment of randomized control trials and the extensive dissemination of impact-evaluation studies. Echoing the way in which CCT programs incentivize "appropriate" behaviors amongst poor families, the multilateral development agencies have been "paying for 
good behaviour" in policymaking communities themselves, insisting that elaborate evaluation strategies must accompany all new interventions, and that the policy-development process must be rigorously evidence-based. This speaks to a new style of transnational policy development, the terms and the terrain of which are preemptively shaped by fast-traveling models like CCTs. But where do these models come from?

\section{Immaculate Invention: Making the CCT Model in Mexico}

It is no exaggeration to say that Mexico's CCT program (Progresa, as it was originally called) was born as a model. But the "iconic" status that it would eventually achieve, to borrow the World Bank's munificent phrase (Fiszbein et al, 2009: 36), would need to be secured through a combination of astute technocratic design and enduring political will. The case for radical reform of the Mexican social-assistance system was pressed in the midst of the Peso crisis of 1994-1995, when it was championed by Santiago Levy (a UStrained economist and senior official in the Ministry of Finance, previously a World Bank consultant on poverty issues) and José Gómez de León (a demographer, director of the National Population Council, and confidant of then-President Zedillo). Fulsome reconstructions of the rationale, justification, and decisive steps that were taken at the time to build and secure Mexico's pioneering CCT program have since been published by Levy (now Vice President for Sectors and Knowledge at the IADB). Levy's (2006) book, Progress against poverty, is effectively presented as a model-making manual.

On Levy's (re)telling, there were three circumstances of the Mexican reform process that were decisive. First, the new approach was theoretically grounded, being predicated on the latest "analytical advances" concerning the multi-dimensional determinants of poverty achieved by economists, sociologists, and nutritionists, which together established the "analytical backbone" for Progresa (Levy, 2006: 10, 11). Rendered in technical terms, these concerned the management of risk aversion, the containment of dependency, and the active engagement of beneficiaries. Second, deliberate attention was paid to the "lessons" from previous Mexican experiences, most of which were deemed to be negative. Previous interventions were judged to have inadequately targeted extreme poverty; they were prone to bureaucratic corruption and political manipulation; and a wide range of inefficiencies was associated with the use of food subsidies. And third, key decision-makers at the time knowingly "use[d] the crisis as a motivation for change," (see above reference: 13) as an opportunity for systemic reform, sold as a single, bold leap to 
world best practice, and designed to bring costs under control in anticipation of long-run budgetary pressure (see above reference: 10, 14, 15).

Here, the refinement of a rigorous conceptual definition of the CCT model preceded not only practical but even political considerations:

[The] challenge $[\ldots]$ was to bring academic researchers' analytical insights and [an] individual nation's best practices together in a unified conceptual framework in order to incorporate that knowledge systematically in the design of the poverty program [...] While the economic crisis created the immediate motivation for change - and the beginning of a new administration naturally created a political climate that facilitated change - the accumulation of empirical evidence, administrative experience, and analytical arguments was fundamental in gradually persuading the members of the Cabinet to make substantive adjustments to the existing food subsidy and related poverty programs. (above reference: 13-14)

This amounted to an extreme form of technocratic policymaking, prosecuted in the teeth of opposition not only from civil-society groups but also from the leadership of the federal government's own social-policy ministry (Teichman, 2009). Exaggerated faith was placed in the kind of economistic technoscience favored by the World Bank, for whom Levy had worked as a professional economist-cum-policy analyst, an organization later credited for "generously provid[ing] technical advice" (Levy, 2006: 114) during the design, piloting, and startup phases of the program. Crucially, however, the involvement of the multilateral development agencies (in particular, the World Bank and the IADB), while formative, was not to be rendered politically legible in the form of a large-scale loan, notwithstanding the severe financial pressures under which the Mexican government was operating at the time. In an instance of mandarin-class bureaucratic understatement, Levy would later explain that, "it was not deemed convenient to obtain international funding for the program [in] 1996-97 [because] such financing would have added yet one more controversial aspect to what was already a fairly significant change in poverty policy, perhaps giving the impression that the program was the result of a mandate or an adjustment program agreed upon with international financial institutions" (Levy, 2006: 114; see also Teichman, 2007; Dion, 2010).

This said, Progresa was in many respects a World Bank/IADB-style project in all but name, since in its basic rationale and fundamental design the program reflected ascendant currents in expert opinion across the multilateral agencies, albeit mostly at the level of conceptual principle rather than (as yet) actually existing practice. In as far as Progresa really was a bold experiment, this was because it sought to capture, and then to act decisively on, a stillemergent expert consensus - what might be called "pre-best practice." Retrospective accounts, however, continue to position the experiment out in front 
of global best practice, which not coincidentally confers leadership status on an inner circle of elite decision-makers in Mexico City. According to one of those closely involved,

[The Progresa] proposal was received with great skepticism and opposition by some Mexican policy makers as well as by international agencies. In Mexico, some policy makers saw the proposal as a 'neo-liberal attempt to eliminate subsidies for the poor' and as 'an imposition by international agencies.' Political parties were concerned about a federal program that would 'give out money,' presumably with electoral and political motives. International agencies thought it operationally and politically unfeasible. (Rodriguez, 2008: 288)

The international agencies, one can perhaps conclude, did not however find the Progresa proposal to be conceptually incoherent. Its model-like rationality would not have been questioned by policy experts in Washington, DC, and indeed the robustness of this rationality - that "analytical backbone"-was the basis on which the audacious experiment was defended during the protracted debate around the program's rationale and design in Mexico City (Levy, 2006; Rodriguez, 2008).

A key strategy of those championing Progresa had been to focus "discussions as much as possible on objective and technical elements," bringing in "well-known national and international experts" where necessary to bolster the case for controversial aspects of the plan, in order to technocratically settle matters "where there had been differences of opinion" (Rodriguez, 2008: 297). Decisively, it would later transpire, a state-of-the-art evaluation framework was built into the program at the design stage, based on a randomized control-group methodology and managed by the well-regarded Washington, DC evaluation house, IFPRI. ${ }^{2}$ Program-design components such as the development of an index of marginality and the specification of targeting and (random) assignment procedures were designed and enacted with nothing short of scientific rigor, even as "[c]ritics, particularly leaders of civil society organizations, expressed moral revulsion at a program evaluation process that involved the use of a control group (10 million Mexicans) who received no Progresa support [on the basis of a purely statistical rationale, so that their] progress could be compared with those who did" (Teichman, 2009: 79). The denial of aid to millions of the rural poor in the midst of a macroeconomic crisis, whose extreme poverty had been meticulously verified as a prelude to assignment to the off-program control group, was deemed a price worth paying, evidently, "to test whether the design hypothesis was correct [...] to quantify the impacts of the programme [and] to determine whether design 
guidelines were being followed and identify if observed outcomes were attributable to implementation or design aspects" (Rodriguez, 2008: 293).

Some would no doubt argue that the greater good was in fact served, since the first results of the IFPRI evaluation-which were interpreted in largely positive terms - became available on the eve of the transition from the Zedillo to the Fox presidency in 2000. The newly elected President Fox was persuaded (by Santiago Levy, whose services he was to retain) not only to preserve the program, but to expand it. Rebranded as Oportunidades, what would become the country's flagship social program was extended to the cities and to other rural regions, eventually reaching one-fourth of the Mexican population and becoming a celebrated test case-cum-lesson for "scaling up success" (Cohen and Easterly, 2009; see also UNDP, 2011). The IADB initiated large-scale funding for the expanded program in 2001, which was soon the object of lavish praise in nearly every quarter of the multilateral policy community.

When James Wolfensohn finished his term as president of the World Bank, in July 2006, one of his first acts as eponymous head of the Brookings Institution's new Center for Development was to commission Santiago Levy to write the definitive account of the Progresa/Oportunidades story. In the foreword to the book, Wolfensohn (2006: vii) rather generously - but certainly not innocently - chose to characterize the Mexican CCT as a "homegrown [program], based on solid economic and social analysis," indeed one premised on an arrestingly "simple idea," generously (but again not innocently) credited to Levy himself. Wolfensohn's hope was that "this volume can serve [...] as a model of effective design of large-scale sustainable poverty reduction programs," since the Progresa/Oportunidades story amply demonstrated that, "in addition to the technical aspects of a poverty program, institutional elements that can ensure adequate scale and continuity are equally indispensable for effective poverty alleviation" (Wolfensohn, 2006: ix-x, emphasis added). As an experiment that worked, the Mexican experience stood as a shining example of rigorous model building, but model building with a purpose. The scientific rationales and rigorous evaluations that had defined this experiment, and which have since sustained it through several transfers of presidential power, were the means to end of a form of technocratic (re)production effectively "insulated" from politics. 


\section{Transnationalizing the CCT Model: a More-than Washington Consensus}

"The widespread distribution of published reports of PROGRESA's outcomes," Sugiyama (2011: 254) notes, "furthered the notion that Mexico had developed a model social program." The model had apparently found its moment. But nothing about this was accidental, of course. The IABD had discreetly funded the IFPRI evaluation program in Mexico from the start, further cementing close relationships between the project's technocratic leadership and the bank (Teichman, 2007), and the evaluation itself had been addressed as much to external audiences as to internal policymaking constituencies. Even though the IFPRI evaluation team relocated to Mexico for three years to manage the project there, the first presentation of the evaluation results took place not in Mexico City, but in Washington, DC.

Little wonder, then, that Aber and Rawlings (2011) credit the ascendancy of evaluation-driven and evidence-based policymaking - especially involving randomized trials - as one of three decisive factors behind the globalization of CCTs. Long maligned as "gray" literature, destined for the back drawers of ministry filing cabinets, evaluation research has been propelled from the shadows to the spotlight in this process, emerging as a significant modelbuilding arena in its own right. Positive evaluation results, especially where these meet the stern tests of statistical validity, have become an international currency of sorts. Progresa's state-of-the-art evaluation not only ensured the program's longevity (especially at the vulnerable moment when the incoming Fox administration had both a clear mandate and a presentational need to break with the Zedillo inheritance), it effectively secured international-model status for the rebadged Oportunidades program, which was (re)born as a validated best practice.

A rigorous evaluation design, based on experimental principles, was literally embedded into Progresa-Oportunidades, initially as a way to insulate the program from the threat of political "interference." (Note that this maneuver positions the imperatives of social-policy technoscience 'above' domestic politics.) Its longer-term impact, though, has been to propel the Mexican program into the center of international debates over social protection, while also contributing to the "culture of evaluation" (Fiszbein et al, 2009: 94) that has enveloped the design and implementation of CCTs worldwide (see above reference: 94-5). Aber and Rawlings state that CCTs "are now arguably the best evaluated development initiative in the Global South," their rapid global spread having been 
fueled by [the] compelling design features [of the paradigmatic programs], their promising evaluation results and the emphasis on knowledge sharing within the CCT and welfare reform community. This experience provides an example of the speed with which innovation can be adopted and scaled up, following a dynamic demonstration effect, with a solid grounding in evidence. $(2011: 7,10)$

As randomized control trials have become the common currency in international policy debates, their high implementation costs impose implicit entry barriers for participation in the global social-protection debate. Since it costs, in effect, several million dollars to ask a question using a randomized-control methodology, only the institutions with the deepest pockets get to determine the questions. This creates a macro selection bias in favor of orthodox interests, issues, and lines of policy development. Evaluations without a significant experimental-design component are also prone to be treated as "softer" and "less scientific," being seen as potentially subject to political manipulation or overselling, and suspect in terms of innate evaluative rigor. The World Bank, other multilateral development agencies, and the leading evaluation houses, on the other hand, enthusiastically promote those programs that have been evaluated using randomized-control procedures, to external audiences as best-practice models with papers.

Not only does this tend to naturalize certain forms (and directions) of technocratic reproduction, it further contributes to the sense that the "big questions" concerning the philosophy and design of CCT programs are firmly settled. The biggest of these concern the efficacy and ethics of conditionalities themselves which are systemically bracketed out in a situation in which the experimental universe is dominated by different kinds of conditional programs and only a few unconditional programs.

If the rise of evaluation science is the first of the drivers of transformation in social-welfare policy identified by Aber and Rawlings, the second concerns the use of incentives in program design, a trend that reflects both the behavioral turn in economic thinking and the political embrace of approaches that "responsibilize" the poor. And just as the behavioral turn has played a part in unifying economic theory, breaking down - in tandem with neoliberalization - some of the old distinctions between a "mainstream" economics ostensibly applicable in the Global North and "development" economics for the South (see Naím, 2000), so too have the policymaking boundaries between different "welfare worlds" (see Esping-Andersen, 1990) become increasingly porous, as policy discourses and debates associated with the Global North and South have become increasingly interrelated, combined, and mutually referential. It has become commonplace to position developments in, say, US social and labor-market policy (like the transition to the Tempo- 
rary Assistance for Needy Families program or the rise of Earned Income Tax Credits) as part of the same "movement" as CCTs, with the Latin American experiments assuming the vanguard, as a moderately disruptive technology. The unifying "focus on a 'hand-up and not a hand-out' has broad political appeal," note Aber and Rawlings (2011: 5), one that has "crossed traditional party lines and is reflected in political discussions and popular debate in both the North and South calling for an emphasis on work, on investing in human capital, on temporary assistance and on co-responsibility between the state and its citizens."

Not coincidentally, such interventions also invoke, hail, and work upon an ostensibly universal economic subject, a rational actor duly enabled to act on her/his own to escape poverty, once appropriate adjustments have been made to the structure of opportunity costs, the patterning of incentives, and the calibration of risk and rewards. Amongst the notable features of the rise of CCTs, in this context, has been a certain leveling of the experimental playing field, as the Global South is reimagined as a potential site of positive programming lessons, and not simply as a location of wicked problems or a "receiving region" for made-in-Washington solutions. The agencies of the Washington Consensus remain deeply involved, of course, but in a situation in which the hubris of unilateral imposition has given way to a more facilitative posture, one that emphasizes the coproduction of expertise with governmental and nongovernmental actors in the South, the enabling of "horizontal" learning across sites and policy fields, and studied deference to welldocumented impact evaluations and evidence of "what works."

In this era of (supposedly) "pro-poor" policymaking, moreover, the language of the incentives paradigm yields obvious presentational advantages: what defines incentive-based programs like CCTs is that they pay for good behavior, in contrast to the negative undertones of workfare-style programs (with their penalties or "sanctions" for "noncompliance"). This said, both negative sanctions and positive incentives work on a behavioralist, "deficiency model" of the poor, since both seek to adjust inappropriate behaviors (dependency, underinvestment in schooling, poor hygiene, etc.) in order to mold more productive and more responsible subjects. CCTs, though, represent the positive side of this coin.

The third driver of transformation in globalizing social policy identified by Aber and Rawlings (2011), in addition to the turns towards behavioralism and evaluation scientism, is the shift in policy thinking and program design towards human-capital focused approaches. This involves what they portray as an historic reconciliation of the imperatives of humanitarian aid and shortterm assistance on the one hand with the goals of long-term economic growth 
on the other, which had previously involved tradeoffs and tensions. CCTs are held to achieve this by fusing cash assistance with future-oriented investments in the children of the poor (see Jenson, 2010). It is recognized that "CCTs are highly ambitious," seeking as they do to "foster human capital accumulation among the young as a means to breaking the inter-generational cycle of poverty" (Aber and Rawlings, 2011: 6), and conceptualizing this as a multidimensional problem and endeavoring to mobilize positive synergies between education, nutrition, and health. With their distinctive emphasis on experimental practice, however, CCTs are credited with "pushing the boundaries of new thinking," (Aber and Rawlings, 2011: 7) as a programming technology positioned at "the threshold of the global policy debate" (see above reference: 1). These boundaries are being pushed in such a way, however, as to consolidate new social-policy orthodoxies, certainly not to upend them.

CCTs, in this respect, can be seen as carriers of a new policy rationality, one that is understood to be continuously in the making in the style of an emergent form of deliberative technocracy. They not only encapsulate the "new thinking" on safety-net policy (see Table 1), which emphasizes social promotion over social protection, responsibilities over rights, and long-term investment over short-term amelioration, but they proactively substantiate an aspirational project located seductively on the threshold of leading-edge realization. This means that while the new generation of social-policy programs are globally diffused technologies, they are far from mature technologies. It is here, for all the uninterrupted soft sell of the best-practice industry, for all the debilitating barriers to entry and selection biases created by the "big science" evaluation regime, for all this paradigm-building momentum, unscripted surprises continue to occur, new mutations appear in the wild, and alternative or vernacular models find their way into the limelight.

Table 1 Conceptions of social assistance, before and after CCTs

\begin{tabular}{llllll}
\hline & Temporality & Philosophy & Tools & Barriers & Goals \\
\hline Welfare & $\begin{array}{l}\text { Assistance in } \\
\text { times of need }\end{array}$ & $\begin{array}{l}\text { Entitlement: } \\
\text { social respon- } \\
\text { sibility for the } \\
\text { poor; } \\
\text { "handouts" }\end{array}$ & $\begin{array}{l}\text { Entitlement- } \\
\text { based transfers }\end{array}$ & $\begin{array}{l}\text { Dependency } \\
\text { culture }\end{array}$ & $\begin{array}{l}\text { Poverty allevia- } \\
\text { tion; social re- } \\
\text { distribution }\end{array}$ \\
\hline Post-Welfare & $\begin{array}{l}\text { Activation } \\
\text { through tar- } \\
\text { geted interven- } \\
\text { tions }\end{array}$ & $\begin{array}{l}\text { Reciprocity: } \\
\text { partnership } \\
\text { with the poor; } \\
\text { "hand up" }\end{array}$ & $\begin{array}{l}\text { Incentive based Access to in- } \\
\text { transfers }\end{array}$ & $\begin{array}{l}\text { Exits from pov- } \\
\text { formation, in- } \\
\text { erty, economic } \\
\text { centives }\end{array}$ & $\begin{array}{l}\text { growth and } \\
\text { human capital }\end{array}$ \\
\hline
\end{tabular}

Source: developed from Aber and Rawlings (2011) 


\section{Multilateral Agencies, Message Control, and its Limits}

In its multiple roles as a funder, evaluator, and technical assistance provider, the World Bank has been directly engaged the purposeful pump-priming and rapid diffusion of the CCT model, and it has been intimately involved in not only steering the course but managing the population of "experiments." In supporting CCT experiments in more than 45 countries, including the provision of $\$ 5.4$ billion since FY 2001 for the development and scaling up of 39 CCT initiatives in 22 nations (Grosh, 2011), the World Bank is positioned de facto as the principal global broker of CCT "best practice," even as (for understandable ideological reasons) this is typically represented in terms of an enabling, facilitating or clearing-house function. In this role as an especially proactive intermediator, the Bank not only finances preferred lines of policy experimentation, it hosts international conferences; it funds and facilitates practitioner networks such as the South-to-South learning network, the "International CCT Community of Practice," and others for midlevel and senior program managers (Fiszbein et al, 2009); and has published countless programming briefs, technical reports, policy presentations, and blogs advising governments on matters pertaining to CCT policy design, implementation, and evaluation.

Across these many channels, the World Bank's policy advice has tended to coagulate around three poles of CCT practice, which effectively define the preapproved reform universe as well as the field of experimentation with CCTs: First (and foremost) the Mexican Oportunidades program, with its sophisticated targeting mechanisms, reliance on unambiguous conditionalities, and inbuilt evaluation infrastructure; second, the newer and relatively smallscale Chile Solidario program, which provides time-limited, highly targeted, and intensive interventions that are strictly contractualized and closely managed by social workers; and third, Brazil's Bolsa Familia, which despite being the largest CCT program in the world credited for measurable reductions in both poverty and economic inequality, has a rather more questionable reputation - in orthodox circles - for having adopted a "softer" approach to conditionalities and targeting. World Bank researchers summarize the relative merits of these three CCT models as follows:

What really makes Mexico's program iconic is the successive waves of data collected to evaluate its impact, the placement of these data in the public domain, and the hundreds of papers and thousands of references to them that this easy access has generated [...] Brazil's CCT provides something of an interesting contrast to the Mexican case in various respects. [It] takes a softer, more gradual tack on conditions [and] puts a shade more emphasis on redistribution than on human cap- 
ital formation. Also, unlike the Mexican program, the Brazilian programs did not explicitly incorporate impact evaluations in their design [...] Chile Solidario [...] differs notably from classic CCT programs by customizing its conditions. Families initially work intensely with social workers to understand actions that could help them get out of extreme poverty, and then they commit to action plans that become the household-specific conditions of the benefit [...] Chile Solidario is thus far a model unto itself, although other programs are moving to emulate it to a degree. (Fiszbein et al, 2009: 36-39)

It is Oportunidades and Chile Solidario, two "model programs" that stress strong conditionalities and social obligations, that are most frequently promoted as appropriate for emulation. In a sense, Bolsa Familia is too large to ignore, but the paucity of officially sanctioned evaluation evidence, the decentralized administration of the program, and what is seen as a "loose" approach to conditionalities combine to deny the program favored model status in World Bank circles. The Bank's definitive report on Bolsa Familia aptly travels under the unassuming title of The nuts and bolts of Brazil's Bolsa Familia program (Lindert et al, 2007). As a leading figure on the international CCT evaluation scene later reflected, "Nuts and bolts" was kind of selfeffacing. "We're just putting the thing together, and this is how it basically works. There was no Model, capital- $M$, selling of it."3 Crucially, what the Brazilian government chose to do with their "non-model" would depart from World Bank orthodoxy on the definitive terrain of conditionalities. In Brazil, the first C of CCTs has a rather different meaning: A member of the World Bank team in Brasilia explained it this way: "[Here], the poor are poor because of a historical process of social exclusion, and we owe them a debt. That's fundamental in Brazilian thinking: They have citizens' rights [but] have not always had access to those rights, and we have to pay this debt back to the poor [...] If I have a child not attending school [but on the] program, are we going to take it [the Bolsa allowance] away? Is my first response a penalty or a punishment? No, our response should be to go and investigate, to use it as a flag-use it as a flag for more care. For them, they would say that the $\mathrm{C}$, as in CCT, is for care. [The idea is] not condition right away, it's not a contract right away." 4

While it may not meet with the approval of World Bank economistevaluators, Brazil's approach of combining soft conditionalities with social rights has resonated with program planners in sub-Saharan Africa, where large segments of the population live in abject poverty and where service de-

3 Evaluation manager, nonprofit research center, Washington, DC, interviewed by Jamie Peck and Nik Theodore, May 2009.

4 Senior manager \#1, World Bank Brasilia team, interviewed by Jamie Peck and Nik Theodore, May 2009. 
livery systems are, by and large, inadequate. Here, capacities for targeting and monitoring are likewise underdeveloped. Correspondingly, CCT programs are less likely to stress conditionalities - partly out of choice, partly out of necessity - and there is often no penalty for noncompliance (Garcia and Moore, 2012). Across Africa's emerging CCT frontier, the centralized and tightly managed Oportunidades program has notably less traction. Instead, Brazil has proved to be a source of more prosaic and practical lessons, as well as a different kind of model for what might involve into less conditional, rights-based CCTs. As a relatively late adopter of CCTs, Africa could potentially be a proving ground for alternative approaches, approaches that are not simply "suboptimal" in relation to the preferred models from Latin America, but which effectively redefine cash-transfer practice en route (see Ferguson, 2010).

Faced with extraordinarily high levels of poverty and social distress, a coalition of civil society organizations in Namibia sought to develop an alternative model of social protection centered on unconditional cash transfers. In the spirit of a citizen's income approach, the Basic Income Grant (BIG) program provides 100 Namibian dollars (\$11.90 US) per month to all residents of the settlement of Otjivero, where unemployment exceeds 70 percent and more than four in ten children are malnourished (Krahe, 2009). While a randomized trial was ruled out as "ethically problematic," a non-randomized evaluation of the two-year BIG pilot project nevertheless revealed promising results: malnutrition plummeted, school attendance and health clinic visits rose, and residents increasingly sought employment opportunities in outlying areas - outcomes that were achieved without the requirements imposed by conditionalities. ${ }^{5}$ Yet the findings from this program have garnered little attention from the World Bank and other multilateral development agencies, and the Namibian program remains something of an anomaly, if not an ideological orphan, in international debates regarding the future of socialprotection policy. Largely overlooked in orthodox circles, the BIG stands as a case of largely unrequited model building, the relative isolation of which stems not from inferior performance but because it challenges the expert consensus in cash-transfer policy, which remains rooted in technocratic approaches to policy design predicated on means-testing, targeting, and, of course, conditionalities.

Countercultural experiments in unconditional cash transfers, such as the Namibian BIG program, may indeed be exceptions that underscore the more

5 Civil society representative, Windhoek, Namibia, interviewed by Nik Theodore, October 2009; senior manager, think tank, Windhoek, Namibia, interviewed by Nik Theodore, October 2009 . 
general rule. But it would be premature to foreclose the possibility of mutation beyond the CCT consensus. In fact, the International Labour Office (ILO) has been taking up this cause in its evolving campaign around the "social protection floor." This relatively progressive current in the multilateral policy debate diverges from the "liberal-residualist" approach of the World Bank, where targeting and conditionality remain axiomatic (if not dogmatic) principles, while at the same time transcending the accommodationalist approach to "capabilities" and "social investment" paradigm favored by the OECD (Jenson, 2010). The Bachelet report on the social protection floor diplomatically acknowledges the achievements of the mainstream CCT programs, but more assertively insists that the debate around conditionalities is "ongoing" (ILO, 2011: 82). Its conclusion that the conditionality "debate remains open" is a position that is echoed on the progressive flank of OECD deliberations on social assistance (see above reference). The more unvarnished articulation of this principle on the Global Social Protection floor website is that "human rights are unconditional, and as social security is a human right, it is therefore unacceptable to deny it through the enforcement of conditions."

Thanks to these and other interventions, there may yet be surprising twists and turns in the global pathways of CCT experimentation. Despite the fact that only a tiny fraction of the massive global "experiment" in cash-transfer programming has been devoted to testing the viability and effectiveness of progressive others to the dominant CCT model - such as unconditional social transfers and basic-income initiatives - a perverse consequence of the singleminded focus on conditionality may have been to beg, by exclusion, questions around heterodox alternatives. Whatever the long-term fate of the ILO's social-protection initiative, this underscores the fact that policy development via model building remains a somewhat uncertain and inescapably political process. Heavily resourced attempts at technocratic (fore)closure will doubtless continue, and they will also continue to shape both reform and the formation of social-policy norms, but all such attempts at formatting, templating, and prescription are destined to remain incomplete and contradictory, no matter how asymmetrical the accompanying power relations. Model power may be formidable, but it is not limitless.

6 Quoted from "Potential and limitations of CCTs," at http://www.socialsecurityextension. org/gimi/gess/ShowTheme.do?tid=2845. 


\section{Conclusion: Post-Political Social Policy?}

Conditional cash transfers are a prime example of especially fast-traveling, if not hypermobile, policies. Realized through an international infrastructure of purposive experimentation and technocratic persuasion, buttressed by the favored evaluation technology of the randomized control trial, the status of CCTs as programs "that work" has been firmly secured in global debates on social safety nets. Sophisticated (and costly) experimental designs have facilitated the construction of a "post-political" veneer around CCTs, the bipartisan appeal of which can be traced to their intriguingly kaleidoscopic character: conservatives see in them a rejection of the something-for-nothing welfare ethos, while liberals place value on progress in realizing social rights for marginalized populations. As a result, CCT models have come to define the innovative frontier in social policy across much of the Global South and in parts of the Global North (Peck and Theodore, 2010), foreshortening policydevelopment phases and often preempting meaningful debate at the same time. These political valences, coupled with the formidable resources (in both dollars and expertise) of the multilateral organizations, mean that the CCT wave has had the benefit of a strong institutional and ideological tailwind, meeting relatively few serious obstacles in its rapid transnational diffusion. Needless to say, the CCT "experiment" would never have been likely to surge from just two or three to nearly fifty countries in the space of a little more than a decade had it been ideologically countercultural or seriously disruptive in political or macroeconomic terms. Quick to implement and badged with expert approval, this model was made to travel.

Through the global diffusion of CCTs, the principle of behaviorally focused interventions, which at least at some level presumes that "corrective" action is both required and legitimate, has been consolidated as a postwelfare axiom across the political mainstream. In this context, fast-moving policy models also exert more subtle forms of normative influence, by establishing parameters around "acceptable" policy options. In some cases, the propensity of best-practice models to arrive on the scene, almost fully formed, as policies that work (albeit somewhere else), can have the effect of forestalling, foreshortening, or completely circumventing processes of local deliberation, debate, and consensus-building around policy reform efforts. Indeed, even in those cases where imported policy models do not directly "format" local responses, they will often exert indirect effects by canalizing and prefiguring the terms of debate. Brazil may have been pursuing a relatively autonomous course as the architect and manager of its own regime of not-really-conditional cash transfers, but at the same time its 
approach is being increasingly "relativized," not least by the purveyors of authorized CCT expertise at the World Bank. Bolsa Familia duly becomes the least-loved corner of a triangular reform universe, with the "iconic" Oportunidades and the "compelling" Chile Solidario occupying the more favored corners (see Fiszbein et al, 2009). The effect of this triangulation strategy is not simply to lift the relatively modest Solidario program into a status of implied equivalence with the big-league players in Mexico and Brazil, it also tilts the field in favor of the two more strictly conditional schemes favored by the Bank. In orthodox circles, there has been no squaring of the triangle through the elevation of Namibia's BIG or other unconditional cash transfer programs, despite their potential applicability elsewhere, although the ILO and others have more recently attempted to destabilize this premature consensus.

Despite the undeniable influence of these best-practice models, backed by the multilateral development agencies and promoted through their distended networks of policy expertise, it would be incorrect to conclude that CCTs have been completely remaking the social-policy world in their own image. The CCT wave seems to be generating its own undertow, and the stubborn question of unconditional cash assistance has refused to go away. Countercultural alternatives to the CCT status quo persist, even as they remain largely sidelined within global policy debates. Meanwhile, unmet, real, and urgent needs in low-income communities around the world demand alternatives that go beyond the new-found orthodoxy of targeted, temporary, and conditional social assistance, which has so clearly failed to reverse decades of immiseration. Sustaining the case for such alternatives will surely necessitate, however, quite different forms of model power.

\section{References}

Aber L and Rawlings L B (2011) North-South Knowledge Sharing on Incentive-based Conditional Cash Transfer Programs. Social Protection Discussion Paper \#1101. Washington, DC: World Bank.

Adato M and Hoddinott J (2010) Conditional Cash Transfers in Latin America. Baltimore, MD: The Johns Hopkins University Press.

Cohen J L and Easterly W (eds) (2009) What Works in Development? Washington, DC: Brookings Institution Press.

Dion M L (2010) Workers and Welfare. Pittsburgh, PA: University of Pittsburgh Press.

Dugger C W (2004) Help Poor be Pupils, not Wage Earners, Brazil Pays Parents. New York Times January 3: A1.

Economist (2010) Give the Poor Money. Economist July 31: 10.

Esping-Andersen G (1990) The Three Worlds of Welfare Capitalism. Princeton, NJ:

Princeton University Press.

Ferguson J (2010) The Uses of Neoliberalism. Antipode 41 (1): 166-184. 
Fiszbein A and Schady N, with Ferreira F H G, Grosh M, Kelleher N, Olinto P and Skoufias E (2009) Conditional Cash Transfers. Washington, DC: World Bank.

Garcia M and Moore C M T (2012) The Cash Dividend. Washington, DC: World Bank.

Grosh M E (2011) CCTs: The Second Generation of Evaluations, Presentation at the workshop "CCTs: The Second Generation of Evaluations," World Bank, Washington, DC, October 24-25.

Hall A (2012) The Last Shall be First: Political Dimensions of Conditional Cash Transfers in Brazil. Journal of Policy Practice 11 (1-2): 25-41.

ILO [International Labour Office] (2011) Social Protection Floor for a Fair and Inclusive Globalization. Geneva: ILO.

Jenson J (2010) Diffusing Ideas for After Neoliberalism: The Social Investment Perspective in Europe and Latin America. Global Social Policy 10 (1): 59-84.

Krahe D (2009) A Basic Income Program in Otjivero. Spiegel Online, accessed at http://www.globalpolicy.org/component/content/article/211-development/48036-abasic-income-program-in-otjivero.html

Levy S (2006) Progress Against Poverty. Washington, DC: Brookings Institution Press.

Moreno-Dodson B (ed) (2005) Reducing Poverty on a Global Scale: Learning and Innovating for Development-Findings from the Shanghai Global Learning Initiative. Washington, DC: World Bank.

Naím M (2000) Washington Consensus or Washington Confusion? Foreign Policy Spring: $87-103$.

Peck J and Theodore N (2010) Recombinant Workfare, Across the Americas: Transnationalizing "Fast" Social Policy. Geoforum 41 (2): 195-208.

Rodriguez E (2008) Beating the Odds: How Progresa/Oportunidades Became Mexico's Major Poverty Alleviation Programme. In: Steele P, Fernando N and Weddikkara M (eds) Poverty Reduction that Works. London: Earthscan, 287-302.

Sugiyama N B (2011) The Diffusion of Conditional Cash Transfer Programs in the Americas. Global Social Policy 11 (2-3): 250-278.

Teichman J A (2007) Multilateral Lending Institutions and Transnational Policy Networks in Mexico and Chile. Global Governance 13 (4): 557-573.

Teichman J A (2009) Competing Visions of Democracy and Development in the Era of Neoliberalism in Mexico and Chile. International Political Science Review 30 (1): 6787.

UNDP [United Nations Development Programme] (2011) Mexico: Scaling up Progresa/Oportunidades. New York: UNDP.

Wolfensohn J (2006) Foreword. In S Levy, Progress Against Poverty. Washington, DC: Brookings Institution Press, vii-x. 



\section{Richard Münchmeier}

Regulating the Poor-Revisited.

Notes on the Shifting Relationship of Social Policy and

Social Work in the German Welfare State

In 1964, the president of the United States of America, Lyndon B. Johnson, declared a special kind of war on a special kind of enemy. He declared the "war on poverty" (Zarefsky, 1986). Faced with a national poverty level of $19 \%$, Lyndon B. Johnson demanded a policy change that would create jobs, secure income replacement, and foster social integration. This demand was to become the 1964 "Economic Opportunity Act," which, to this day, is celebrated as a groundbreaking piece of legislation. It was a breakthrough in governmental strategy, because it no longer simply relied on police intervention and repression, but instead developed relief programs in the area of job creation, but, notably, also in the areas of education and training, health promotion, and general wellbeing.

Seven years later, Frances Fox Piven and her husband, Richard A. Cloward, who at that time lectured in social politics and social work in New York, published a book, in which they attempted to expose the putative breakthrough of the "war on poverty" as a short-term effect. They sought to define the programs rolled out under the Economic Opportunity Act as a mere phase within the larger process of contractions and expansions in social politics. Entitled "Regulating the Poor. The Functions of Public Welfare" (Piven and Cloward, 1971), this book triggered controversy and debate in both the political and scientific spheres as soon as it was released, and it became a seminal work of theory for the protest and civil rights movements in the U.S. Following a variety of critical reviews, the authors produced a revised and extended version in 1993, in which they tried to define their basic ideas more precisely, and to extend the application of these ideas to include a period up into the 1990s.

As the title of this article indicates, I will be making my deliberations with reference to this book. My primary concern here, however, is not so much the empirical validity of all the details of American politics from Roosevelt to Reagan (see Dodenhoff, 1998). Instead, my main interest is in exploring the theoretical model, i.e. the explanation that underpins the authors' 
attempts to understand the ups and downs of social politics, with its characteristic oscillations between expanding welfare programs and rigid financial curtailment. In addition to this, I will also use the theory of Piven and Cloward on the function of public welfare policy to examine the following two points in sequence: first, the historical differences in the development of public welfare policy that exist between Germany and the U.S. and, second, the recent changes in German social politics, focusing in particular on the question of whether this has become "Americanized" or, in other words, whether an American understanding of society has been adopted.

\section{The Function and Strategy of Welfare Politics in the U.S. (According to Piven and Cloward)}

In their 1993 book, Piven and Cloward summarized their interpretation of the function of social policy right from page one, with some short and provocative wording in the preface stating: "relief arrangements [...] have a great deal to do with maintaining social and economic inequities" (see Piven and Cloward, 1993: XIX). These are tough words that attack not only the success stories of social work but also its very nature, given that the self-concept of social work is one of operating under the banners of "assistance" and "equalization." In essence, its social function, so Piven and Cloward, comes down to the question of "how some people are made to do the harshest work for the least reward" (see above reference).

According to their analysis, it is this basic function that underlies the long cycles of expansion and contraction of social support. These run countercyclical to the prevailing phases of the economy and, thus, reflect the rise and fall in unemployment and social disintegration. There is yet more, however: with the help of historical analyses, the authors demonstrate that simply "supporting" the disadvantaged is not the main issue; instead, the crucial point is "regulating the poor," or, put differently, controlling and guiding their behavior. Further, they claim that linking socio-political aid programs with behavior control through the means of social work was necessary to avoid civil disorder. Therefore, a willingness to work would not be sufficient. Being willing to integrate into the existing social environment, accepting the constraints of one's present life situation, adopting basic social standards and values, learning to act responsibly, and taking initiative would also be required. For this reason, the interlinking of social, anti-poverty, or unemployment policies with both social work and person-centered socialization strategies would be inevitable. The provision of relief would thus be conditional on 
changes in the recipient's behavior. In the words of Piven and Cloward: "Relief arrangements deal with disorder, not simply by giving aid to the displaced poor, but by granting it on condition that they behave in certain ways" (see above reference: 22 ).

Insights from modern social politics gained under the conditions of a capitalist system underpin this concept and can be summarized as follows: "simply providing aid to quiet the unemployed will not stop disorder; it may even permit it to worsen, for although the remedy may prevent workers' starvation, the trigger that sets off disorder is not economic distress itself but the deterioration of social control. To restore order, the society must create the means to reassert its authority. Because the market is unable to control men's behavior" (see above reference: 7).

The short list provided below describes the theoretical model of modern social politics, as envisaged by Piven and Cloward:

- Superficially, welfare aid is a means of supporting the needy; at its core, however, it is a tool to ensure that the order of state and society is retained or reinstated.

- Therefore, any provision of help is conditional on the regulation and control of behavior. Support is made dependent on the willingness to integrate.

- The risk of the erosion of societal order increases during periods of economic crisis. As a consequence, relief programs have to be expanded at these times.

- Once a period of economic crisis has been weathered, it is necessary to scale back the previously expanded programs, to avoid the risk of creeping habituation (and with this, the risk of destroying core standards, in particular, the duty to work).

\section{The Case of Germany: A History of Task Separation Between Social Politics and Social Pedagogy}

If the development of the German welfare system is viewed through this interpretational lens, striking differences immediately become apparent. In particular, this applies to the intermeshing of support provision and behavior regulation, and also to the conditionality of aid upon controlled behavior. In the context of the German storyline, a determined separation of material from non-material support, including counseling, education, training, and therapy, was apparently central to shaping the structure of its welfare system. 
In fact, a 'dual structure' specific to the German welfare system emerged during its development in the last third of the nineteenth century (see Sachße and Tennstedt, 1991: 441). According to this, tasks that either deal with securing a livelihood or providing support in cases of a material emergency are governed by social insurance and welfare aid legislation. While social work - in the sense of a pedagogical self-concept-is focused on personcentered services that are educative or psychological in nature, such as, among many other activities, counseling, individual case work, social group work, educational support, and re-socialization opportunities. Indeed, social work in Germany would not have been able to develop its specific sociopedagogical self-concept without this sort of division of labor. Its creation and development, therefore, can be told as a tale of the ever-expanding roles of pedagogy and psychology (see Münchmeier, 1981).

The most important existential risks for the working classes-disability (inability to work), sickness, advancing age, and unemployment - were therefore to be covered by insurance benefits (the so-called "social insurances"). Although this entailed contribution payments, the entitlement to claim in the case of a contingency was enshrined in law. The first piece of legislation to be passed was the health insurance law of 1883. This was followed by the statutory accident insurance in 1884 and the statutory disability and old age insurance (i.e. a pension) in 1889. It was not until 1927 that unemployment insurance was to join them. The socio-political aim of these insurance schemes, which had been sanctioned by law, was to stop poverty arising in the first place by offering an effective prevention. In turn, this permitted the system of poor relief to enter into an arrangement with social politics and arrive at a sort of division of responsibilities by reorganizing itself according to social principles. These principles were no longer repressive in outlook, but were instead aligned with the ideas of social pedagogy.

Through this "dual structure" of monetary benefits and pedagogic assistance - the division of social policy into material support, on the one hand, and social pedagogy, advisory services, and socialization opportunities, on the other hand - it was possible to mitigate and dilute the main criticism and resistance from the early labor movement. Social democratic organizations had actually opposed the idea that welfare for the poor should be structured around pedagogical principles, because it did not include any material improvement of living conditions. They argued that this new form of poor relief handed out "kind words instead of bread", meaning that it dispensed advice and appealed to people's sense of moral duty without making the slightest difference to their material existence and situation in life. In this way, the poor would be subjected to the haphazard and unreliable charity of old. They 
would be disempowered by the legitimization of aid providers to interfere in their ways of life and behavior, and to distribute aid according to questionable and uncontrollable standards of who is "deserving" and who is "undeserving." For a long time, therefore, the labor movement had been calling for charity to be replaced by legal rights that would come into action when specific factual circumstances were met, regardless of the standing or behavior of a person, and which triggered aid payments according to pre-agreed sets of measures and amounts. They termed this principle "objective welfare," because it did not consider specific subjective characteristics or conditions, but instead only took into consideration the degree of need as assessed by objective criteria.

It was precisely this fundamental "legalization" of material support provision without the consideration of a person's standing that came into existence with the introduction of the social insurance laws, although only relatively few workers were able to benefit from this in the beginning. At the same time, those providing poor relief, which was becoming ever more tightly focused on a pedagogical approach and would be known as "social work" only a few decades later, were able to deflect accusations of merely offering "kind words" by pointing to the social insurance system.

Under the auspices of the state, the institutionalization of material support, which was increasingly established through legally binding indemnification, meant that the initial development of a welfare state in Germany followed a different pathway to that reconstructed by Piven and Cloward for the U.S. It enabled a specifically German, pedagogical focus of welfare, which in turn allowed social pedagogy to develop as an autonomous system outside the traditional structures of poor relief (see Münchmeier, 1981).

\section{The Rise of Pedagogy in German Welfare}

With the separation of welfare tasks and the legal protection of material support in place, the old system of poor relief in Germany was superseded by a new system of support that was characterized by a new pedagogical understanding of itself. The contemporary expression for this development at the end of the nineteenth century was the "social organization" of welfare.

The associated trend of taking a pedagogical perspective of the definition of problems and tasks had begun earlier, during the last third of the nineteenth century, when the organization of poor relief according to social principles initially started. The adoption of a pedagogical outlook was synonymous with a gradual, step-by-step change in the perception and interpretation 
of the causes of social problems and the ways in which these problems should be solved (see Münchmeier, 1981: 82-84). Over time, two patterns of thought have become established:

(1) The problems that are relevant to social work are defined as primarily pedagogical in nature: i.e. as developmental, learning-related, motivational, or moral disturbances, etc. Importantly, what constitutes an historical transformation of a social problem of cumulative disadvantage into a pedagogical problem of developmental and educational deficits, is not an associated reduction in material hardship, but instead an associated change in the way the welfare state addresses the problem. The more the nature of material hardship was interpreted in the light of socialization theories and, thereby, effectively moved into the sphere of personal circumstances, the greater the historic opportunity became for the welfare state to no longer simply deny the existence of social misery, describe it as a passing phase, or downplay it in any way. Instead, the welfare state was able to acknowledge social misery and, at the same time, tie it to a reason for intervention that would limit public commitment, as this reason was based on influencing the individual and on the idea of one fellow human being helping another.

(2) In analogy to the above, there is the view that finding a solution to social hardship requires above all else a change in the behavior of those who are affected. Only through this hypothesis of intervention can the goal of a social work-related intervention be understood. In the face of social hardship, pedagogical intervention would become nonsensical and impossible to undertake in a rational way, if the necessary solutions are not first converted into "steps of learning" and "gains in maturity" on the part of the disadvantaged. Shifting the focus of the intervention on to the person and his/her behavior does not, however, mean that the importance of external material needs is denied. On the contrary, it reflects the assured claim that no external hardship, whatever its nature, is not also paralleled by the simultaneous presence of an inner need. The following quotation is characteristic of this point of view, which is becoming increasingly widely established: "However, if you see a poor man as a human being in his totality, then every case of destitution will, as it were inevitably, be associated with a psychological problem" (Hetzer, 1929: 3 [orig.: German]).

In this point there is overlap with the views of Piven and Cloward. They too interpreted the historical developments in such a way that the provision of material aid alone, i.e. financial support without education or behavioral changes on the part of the recipient, would be perceived by the majority of society as ineffective or even as worsening the original problem. In Germany, 
however, the debate is focused less on controlling the politico-social alignment of the disadvantaged, and more on the pedagogic and psychological paradigm of the poor. The fact that material and person-centered support can also be differentiated in terms of the institutional boundaries that have been drawn within the welfare state reflects the impact of this debate.

\section{Incorporating Pedagogy Into Social Work-a Process Fraught with Contradictions}

When looking at the next steps in the development of the German welfare system, it becomes obvious that the "money versus person" separation did not run smoothly from the start. Theory and practice were caught up repeatedly in the contradictions that were inherent in the above-mentioned dual structure and the pedagogical focus of social work. These contradictions surfaced time and again.

Social work repeatedly stumbled over the fact that societal causes were at the root of subjective and individual problems. A vast knowledge base on the structural and social reproducibility of individual problems was accumulated through the practice, research and theory of social work. Therefore, regarding its interventional strategies, social work was confronted with a lack of success owing to its structural set-up. After all, dispensing advice to the unemployed does not create job vacancies. Similarly, group work with the socially disadvantaged will not touch the causes and/or reach the perpetrators of this disadvantage. Such insights grew stronger in the 1960s and 1970s, when social science studies came to prominence and took over in importance from psychology-based theories. At the same time, this knowledge proved "cumbersome" in practice, because it went beyond any of the given institutional, legal and political possibilities of action that were open to practitioners. "If social structures, their origins and reasons, etc. were to be incorporated into a regression analysis of causality, then the chain of causality would lead into areas that lie outside a social worker's current range of remit. A sociological analysis would make a single case appear to be a concrete illustration of generally applicable factors, and thus suggest a course of action to the social worker that goes beyond the concept of "one fellow human being helping another"" (Peters, 1973: 161 [orig.: German]; see Peters and Cremer-Schäfer, 1975).

From this dilemma, three supporting strategies have arisen to stabilize the pedagogical base-paradigm: a strategy of politicization, a strategy of moralization, and a strategy of socio-politicization and socio-political obligation. 
The strategy of politicization: This strategy refers to social work demanding political solutions to the problems it encounters. The tension that exists between society causing and individuals enduring situations of social hardship creates and continually drives the need to take political thinking and problem solving to the next level. It also leads to calls for an effective social reform policy. If the pedagogical response to social problems is not to be labeled as cynical (in that it would correspond to the "kind words instead of bread" allegations of the labor movement), then a political context for social reform is essential for the type of social work that operates under a pedagogical banner. Such pedagogical social work needs a social policy that can shape living situations, supply the resources that are required for daily living (in particular, the opportunity to earn a wage), tackle social injustice, and ensure a socially fair distribution of opportunities and risks as well as developmental burdens and chances. It requires a policy of "including everyone."

Consequently, the boundaries between pedagogy and material help that exist within the dual structure of the welfare state have to be made porous and crossed time and again. In this sense, the German model of two separate systems is again starting to resemble the intermeshed system that is found in the U.S.

The strategies for marginalized groups developed in Germany in the 1970 s by a group of critically minded social workers serve to illustrate the disintegration of task-related boundaries within the dual structure. The hallmark of these strategies was the politicization of the social workers' clientele, who in this way were maneuvered "into position politically." The ultimate aim was to exert pressure on policy makers, through the pooling of interests and the mobilization of the disadvantaged, and to push for the political solution of problems.

Another example includes the community work projects that were undertaken in Germany. These projects attempted to take the shared concerns of people whose lives were blighted by infrastructural deficits or social flash points, and to turn these, at the level of local government policy, into initiatives for the restructuring of communities and the improvement of livelihoods.

In this context, the so-called "strategy of interfering" has come to particular prominence in Germany. Its "inventor," Ingrid Mielenz (1981), insists that social work - specifically, in this case, child and youth welfare servicesshould not be allowed to find its limit in the provision of person-focused psychosocial help, but should instead interfere in other policy areas in order to protect its clients' interests at a political level. According to the fundamental idea behind this concept, German child and youth welfare services could only 
fulfill their responsibilities if they cooperated with or, if need be, confronted other areas of political jurisdiction and policy making.

This fundamental idea famously appears, no less, in paragraph \# 1 of the "Kinder- und Jugendhilfegesetz (KJHG)," Germany's child and youth welfare services code, which specifies that a young person's legal right "to the advancement of personal development and education" means that the services should "contribute to creating and sustaining a child- and familyfriendly environment" (paragraph \# 1 (3) $4 \mathrm{KJHG}$ ).

The strategy of moralization: To enable and legitimize its adoption of pedagogy, social work requires a socio-moral postulate of justice (Rawls, 1999). It is, therefore, forced to repeatedly make moral demands. Indeed, to gain legitimacy of its status as an educative authority, social work must insist on a public policy that is receptive to the "soft" postulates of emancipation, equal opportunities, education, and self-fulfillment. By taking this approach, social work attempts to introduce basic pedagogical concepts and standards into the system of social politics, where they will be subject to implementation difficulties and budgetary limitations.

In this respect, German social work experienced a comparatively ideal environment during the 1970s. During this time, the then-governing socialliberal coalition publically and politically defined a very clear postulate for a fair and egalitarian society of equal opportunities, and declared this to be the goal of their social reform policy. Without this connection between the political and the public dimensions, it is difficult to maintain the concept of adopting a pedagogical approach.

So, yet again, social work is confronted with the question of how to interpret the relationship between a subjectively problematic situation and an unjust society? Does the focus on pedagogy not lead to the privatization, familiarization, and de-politicization, i.e. to "individualization" in its negative sense, of what should actually be the responsibility of society as a whole?

The strategy of socio-political obligation: Of course, the moralization strategy that is outlined above puts social work in danger of exceeding the limits of what is politically possible and enforceable. Particularly, when it comes to comparatively complex problems that are triggered by multiple diffuse causes, German politicians and authorities tend to delegate the task of problem solving back to social work. They make it, as it were, the duty of social work to take responsibility for finding a solution to social problems. For example, even as early as in the late 1970s, reports on Germany's social affairs picked up on the socio-political obligation that the German child and youth welfare services were under and rejected this trend (see Bundesministerium für Familie, Jugend und Gesundheit, 1978). 
Nonetheless, a host of state-run programs have meanwhile become established that all take advantage of social work in terms of finding solutions to a wide range of public problems, including xenophobia, hostility towards specific groups, the phenomena of societal drop-outs and escapism, or even the increasing loss of civic solidarity, dangerous radical sects or groups, the increased use of violence, political dissatisfaction, the risk of burnout, school absenteeism and many more issues. In addition, the German state is now switching from an approach of institutional funding of social work to an approach of program control, at all levels. The greater the extent of these switches is, the more effective the state becomes in making social work research and practice adopt socio-political aims, and also in exerting control over them in the sense of service and quality agreements.

Seen from the perspective of Piven and Cloward, this is leading to the dissolution and breach, by politics, of the structural boundaries between social policy and social pedagogy. So, what remains of the dual structure of the German welfare state as outlined above, and what remains of its muchpraised tradition?

\section{From the Welfare to the "Activating" State: Regulating the Poor Revisited}

Germany's dual structure has enabled and shaped the development of German social work over the past 140 years, by virtue of dividing labor between social policy, which is responsible for securing livelihoods, and social work, which is responsible for providing non-material assistance to individuals. If one concedes that this arrangement has always been fragile and in danger of being obscured, then the most recent signs point towards the venerable dual structure seemingly vanishing altogether. At least, this is true for a specific area: the area of labor market policy and unemployment support, which has been reformed primarily through the introduction of what has come to be known as the "Agenda 2010," devised by the German chancellor of the time, Gerhard Schröder, and by the so-called "Hartz-IV" legislation, which came into effect in 2005.

If, compared with historical data, the current overlap between material and pedagogical services in the German welfare state could be shown to be expanding, then this would indicate that the proposition of Piven and Cloward (1993) is becoming more applicable: in other words, social work is contributing significantly to the disciplining of the impoverished. The following observations are intended to test this hypothesis. 
The concept of an "activating" state has been discussed for the best part of the last 25 years, and it has found its chief expression in German law in the so-called Hartz-IV legislation (see, in particular, book II of the German Social Code [Deutsches Sozialgesetzbuch II]). In the dual principle of "encouragement and challenge," which is stipulated in this legislation, commentators see "a certain turning away from the concepts of the welfare state that have been handed down up until now" and assume that this "paradigm shift [...] may lead to a more stringent social control of the unemployed" (Münder, 2006, introduction, paragraph \# 6 [orig.: German]). A change in the system of public and social policies had been called for in the U.S. since the 1980s, under the slogan "from welfare to workfare." This concept reached Europe predominantly through the "New Labour" program that was spearheaded by then prime minister of the United Kingdom, Tony Blair, and which referred to the work of the social democratic theorist, Anthony Giddens. In the case of Germany, the "welfare to workfare" concept was translated into practical political suggestions by the Hartz commission, who based their proposals on the philosophy expounded by Gerhard Schröder in the "Agenda 2010."

It is not only the crisis of an employment-centered society or the fiscal emergency of public sector budgets that are the reason for this paradigm shift. The program of the activating state represents more than a mere austerity measure. It incorporates the propositions of welfare-state critics, such as Esping-Andersen (e.g. 2002), concerning the functional deficits of traditional welfare politics, and it demands a fundamental conceptual change in direction. The following statements encapsulate some of the functional criticisms: the states welfare services destroy the citizens' motivation to work (the argument of "reclining in the welfare hammock"); the scope and depth of the services are too large and therefore not affordable (the argument of cost); and social services are usually non-reciprocal, thus increasing the passivity of the claimant. Finally, welfare services are funded by the contributions of the employed, thus the payment of income benefit to those among the unemployed who could work, but choose not to, means that a demographically already unjust situation is set to worsen: ever fewer people in employment will have to support ever more people claiming insurance benefits.

Accordingly, the principles of the "Third Way" (Giddens, 1998) state the following: no service without reciprocity; an absolute commitment to work by those receiving employment benefits; creation of a low-paid sector for the long-term unemployed or those who are difficult to place; sanctions (for example, a cut in income support), if the claimant refuses to cooperate or shows no self-initiative; and a duty of the social employment services to establish or re-establish the "employability" of risk groups. The strong emphasis on the 
claimant's "duty to cooperate" signifies, at least in a symbolic sense, that support has to be "earned". The relevant stipulation can be found in volume II of the German Social Welfare Code:

Paragraph 2: The principle of demand.

(1) Persons who require social support and who are capable of gainful employment, and their dependents, if they share the same household, must exhaust every possibility to end or reduce their need for support. Claimants who are capable of gainful employment must actively cooperate with all measures that are undertaken to facilitate their reintegration into employment; in particular, they must enter into a reintegration contract. If employment within the general labor market is not possible within a foreseeable period of time, then a claimant who is capable of gainful employment must accept any reasonable offer of work that they receive.

(2) Persons who require social support and who are capable of gainful employment, and their dependents, if they share the same household, have to take responsibility themselves for exhausting every possibility that lies within their own means and powers to secure their livelihood. Claimants who are capable of gainful employment must utilize their ability to work for the purpose securing a livelihood for themselves and for their dependents, if they share the same household.

How seriously the rules governing the behavior of claimants are taken, is reflected in the legal definition of the "capacity for gainful employment":

Paragraph 8: Capacity for gainful employment. (1) If not prevented by sickness or disability in the foreseeable future, a person is considered capable of gainful employment if they can work for a minimum of three hours a day under the conditions of the general labor market as they usually apply.

The "encouragement and challenge" maxim for action makes it obvious that the realization of a new social policy has also created new objectives, responsibilities and functions of social work. It, too, has to align interventions and services with the aim of maintaining or re-establishing employability. In future, the classic tools of social work-consultation, care, support, and development of assistance plans - have to be integrated into the modules that are specified by law, namely: assessment (checking the placeability of a claimant), profiling (at the job placement center), contracting (handling the support agreement), and case management. This means that the assistance offered by social work has to be allied with the primary goal of reintegration into the world of work. If this assistance does not appear to promise success, it should be discontinued and proof of employment opportunities should be provided instead.

With social policies being structured in this new way, it is clear that the long-established interplay between politics and pedagogy, or in other words, 
the historical division of labor between social politics and social work, requires re-organization and adjustment: From this point onwards, the purpose of social work is behavior control, with the aim of achieving placeability in the labor market. Personal responsibility and flexibility, a willingness to adapt in terms of job location, and active self-help are the new goals of socialization and education strategies. The most crucial point here is that these goals can be enforced by repressive means (even going as far as cutting income support).

According to the analysis in our reference theory by Piven and Cloward (1993), these are observations that classically typify the concept of "Regulating the Poor." In addition, a tendency for repressive aid provision, once believed to be an historic relic long left behind, is apparently again making its presence felt in the arena of social work. This tendency goes far beyond the basic dilemma of help and control that is much discussed in social work theory, and is openly repressive in nature. It was precisely the pedagogical approach, meaning its separation from the authorities of control and sanction, that was the pride of Germany's social work professionalism. Education instead of regulation, consultation instead of interference, offers instead of enforcement, and support a person's own strengths in place of control and supervision were considered central maxims of a forward-looking and modern practice that had finally overcome the ideas of authority and control belonging to the old style of welfare.

The politics of an activating social state take the direction of "lifestyle politics." German social work of the past decades emphasized a focus on the everyday life of their clients, and in doing so, always claimed to want to influence and improve conditions. In other words, it aimed to practice a preventative approach and provide resources and conditions tailored to the social environment in order to assist with the problems of daily life. In contrast, the new "workfare" concept emphasizes a strategy of molding behavior. The new strategy does not rely on a correction of economic market rules by regulatory or socio-political approaches. It does not seek to fix the failures of the market as in the Keynesian concept. It is not concerned with external "conditions," but instead explicitly exerts influence on "behavior patterns," attitudes, and mentalities, with the aim of conforming these to the existing conditions. Inappropriate types of behavior, such as inflexibility, convenience, aspirations, and a mentality of dependency, etc. have to be changed or corrected. As such, social politics regains a character of education politics, or as Giddens puts it, "life politics" (Giddens, 1998: 90), in particular, where the distribution of income benefits is concerned. This indicates that the classic dual structure of the German welfare state is breached in another way: not only is social work 
increasingly characterized by regulatory policies, but regulatory politics, too, are increasingly characterized by policies borrowed from social work, because these are more pedagogical.

At the same time, this also precipitates changes in the aim and content of what constitutes "pedagogy." The use of pedagogy as a facility to promote personal development, the acquisition of key competences, learning opportunities and the introduction to culture and tradition - in brief, a facility of enlightenment in the sense of autonomy and emancipation - is relegated to a secondary role. Primarily, now, it is used as a facility of standardization, social control and assimilation. The threat of exclusion is its means of sanctioning.

Marginalized groups and those under threat of exclusion, such as recipients of social benefits or the unemployed, are the main targets of the activating state. For this reason, they are also the main recipients of its education efforts. Nonetheless, this practice sends out waves, acting as a warning to all citizens, especially those at "the middle level" of society:

Enabled by the tool of social exclusion, the social politics of demand take on the role of an educator and, precisely through this step, attempt to achieve the reproduction of shared values. After all, social exclusion is supposed to create a stronger commitment to these values among those, who are prepared to fulfill their 'duties', and who themselves, in turn, expect all of those included in the system to do the same. (Lahusen and Stark, 2003: 370 [orig.: German])

\section{Summary}

For the first time in the history of the German welfare state, there appear to be signs of a break with tradition, for example, in the areas of labor market policy and unemployment benefit. The defining dual structure is becoming fragile, and this will and must have consequences for social work. These consequences will extend beyond unemployment benefit to other activities, possibly, in the sense that a new type of two-tier system or differentiation will emerge in German social work. On the one side, there will be the social work that applies to normal, integrated citizens. This will be based on offers and voluntary participation, with the aim of a general improvement in quality of life. On the other side, there will be the social work that targets problem groups and marginalized citizens, and this will be based on making demands and exerting social control (or even compulsion and repression). Here, the aim will be to achieve, through encouragement or enforcement (in the worstcase scenario, through the stabilization of exclusion), a willingness to exercise self-help and integration (see Münchmeier, 2007). 
In my opinion, why this vision of the future, which is described by Piven and Cloward as a social process that has already taken place in the U.S., is not yet a reality in Germany is due to two factors. For one, because of the German state policy of compensation, fluctuations in the economy do not lead to the same degree of widespread poverty in Germany as they do in the U.S.; in other words, state intervention buffers the negative economic consequences. For the other, the ideas of social justice and the proverbial "social peace" that is built upon these ideas still provide sufficient levels of cohesion and social solidarity, to spare Germany the sort of riots and mass movements that were, and still are, a typical part of the history of the U.S., and therefore played a central role in the theories of Piven and Cloward.

\section{References}

Dodenhoff D (1998) Is Welfare Really About Social Control? Social Service Review 72: 310-336.

Esping-Andersen G (2002) Why We Need a New Welfare State. Oxford: Oxford University Press.

Bundesministerium für Familie, Jugend und Gesundheit (ed) (1978) Fünfter Jugendbericht. Bonn: Bundestragsdrucksache 8/3665.

Giddens A (1998) Beyond Left and Right: The Future of Radical Politics. Cambridge: Polity Press.

Hetzer H (1929) Kindheit und Armut. Psychologische Methoden in Armutsforschung und Armutsbekämpfung (Psychologie der Fürsorge. Band 1). Leipzig: Hirzel Verlag.

Lahusen C and Stark C (2003) Integration. Vom fördernden und fordernden Sozialstaat. In: Lessenich S (ed) Wohlfahrtsstaatliche Grundbegriffe. Historische und aktuelle Diskurse. Frankfurt am Main: Campus Verlag, 353-371.

Mielenz I (1981) Die Strategie der Einmischung. Sozialarbeit zwischen sozialer Kommunalpolitik und Selbsthilfe. In: Neue Praxis. Sonderheft 6: 57-66.

Münchmeier R (1981) Zugänge zur Geschichte der Sozialarbeit. Munich: Juventa Verlag.

Münchmeier R (2007) Zwischen Zuwendung und Ausgrenzung_-Die Zukunft der Sozialen Arbeit im Bereich der Jugendhilfe. In: Hering S (ed) Bürgerschaftlichkeit und Professionalität. Wirklichkeit und Zukunftsperspektiven Sozialer Arbeit. Wiesbaden: VS Verlag für Sozialwissenschaften, 199-204.

Münder J (ed) (2006) Sozialgesetzbuch II. Grundsicherung für Arbeitssuchende. Lehr- und Praxiskommentar. 2. Auflage. Baden-Baden: Nomos Verlag.

Peters H (1973) Die politische Funktionslosigkeit der Sozialarbeit und die ,pathologische“ Definition ihrer Adressaten. In: Otto H-U and Schneider S (ed) Gesellschaftliche Perspektiven der Sozialarbeit. Band 1. Neuwied and Berlin: Luchterhand Verlag.

Peters H and Cremer-Schäfer C (1975) Die sanften Kontrolleure. Wie Sozialarbeiter mit Devianten umgehen. Stuttgart: Enke Verlag.

Piven FF and Cloward RA (1971) Regulating the Poor. The Functions of Public Welfare. New York: Pantheon.

Piven FF and Cloward RA (1993) Regulating the Poor. The Functions of Public Welfare. Updated Edition. New York: Vintage Books.

Rawls J (1999) A Theory of Justice. Cambridge, MA: Belknap Press. 
Sachße C and Tennstedt F (1991) Armenfürsorge, soziale Fürsorge, Sozialarbeit. In: Berg $\mathrm{C}$ et al. (eds) Handbuch der deutschen Bildungsgeschichte. Vom 15. Jahrhundert bis zur Gegenwart. Band 4: 1870 bis 1918. Von der Reichsgründung bis zum Ende des Ersten Weltkrieges. Munich: C.H. Beck Verlag, 411-440.

Zarefsky D (1986) President Johnsons War on Poverty. Rhetoric and History. Tuscaloosa: University of Alabama Press. 
III. Case Studies on Continuity and Change in Selected Western Welfare State Settings 



\section{Robert P. Fairbanks II}

\section{Recovering Post-Welfare Urbanism in Philadelphia and Chicago: Ethnographic Evidence from the Informal Recovery House to the State Penitentiary}

This chapter focuses on a selective scale of welfare state transformation in two postindustrial U.S. cities: Philadelphia and Chicago. Specifically, the chapter explores ethnographically and theoretically the relationship between the restructuring of urban and state-level social welfare systems, on the one hand, and informal street-level urban poverty survival strategies, on the other. A central objective of the chapter is to understand the nexus between the lived experience of addiction/recovery and the implementation of social welfare policy and practices reforms. I seek to understand how this nexus differentially distributes life opportunities for poor and predominantly African American drug users. In this respect, my work is situated in a long line of scholarship that envisages welfare systems as fundamentally stratifying institutions, insofar as they differentially distribute rights and opportunitiesoften along racial, class, and gender lines.

And yet while the stratifying functions of welfare practices have long been recognized, there has been a paucity of empirical work on matters concerning the transformation of regulatory imperatives in urban poverty governance and political economy. This chapter takes as its object the regulatory principles that continuously shape (and are shaped by) the sifting and sorting mechanisms of contemporary welfare arrangements. Through the use of two ethnographic case examples, the chapter contends that nuanced transformations operating across institutional scales-from the micro to the mezzo and macro level-are essential to the project of making and remaking of citizenship in accordance with the broader political economic mandates of late capitalism. A central analytic objective is to illustrate how welfare arrangements-albeit perhaps in altered form and yet still or even especially in an era of market liberalism - are more necessary than ever for the empowerment of a new class of market actors. Welfare arrangements are continuously essential to setting the rules of the game; the conditions of possibility for the management, regulation, and governance of problem or surplus populations. 
In order to get a view onto these processes up close, my work on two ethnographic examples allows us to unpack the ways in which state building projects - formal or informal — entail a making and remaking of race, rights, and citizenship in accordance with the regulatory imperatives of the welfare state and the political economy of the contemporary United States. The first case derives from Fairbanks (2009); while the second derives from the fieldwork for a second book in progress. ${ }^{1}$ In both studies, my analysis provides empirical and theoretical nuance to the pressing questions explored by the authors of this volume: how can welfare scholars discern historical, geographical and political novelty from continuity in the institutionally inherited landscapes of welfare state transformation? I will explore this question in the two ethnographic examples that follow.

\section{The Philadelphia Recovery House Movement}

The city of Philadelphia is home to more than 60,000 vacant properties, 30,000 of which are abandoned row homes. The former textilemanufacturing neighborhood of Kensington, in the city's northeast section, an iconic locale for Philadelphia's rust belt woes, is the site of ethnographic research for this study. Originally comprised of British, German and Irish immigrants, Kensington stands today as a remarkable instance of racial diversity at roughly 30\% African American, 35\% Latino, and 30\% white. The neighborhood has been disproportionately ravaged by deindustrialization as $75 \%$ of Philly's manufacturing base dissolved in the postwar era. Today, $55 \%$ of Kensington lives below the poverty line and $40 \%$ of properties are classified as vacant. More than half of the population is detached from the labor force, with over $50 \%$ receiving some form of public assistance. The epicenter of my fieldwork, affectionately dubbed "K\&A" to denote neighborhood around the intersection of Kensington and Allegheny Avenues [zip code 19134], also leads the city in drug arrests (sales and possession); as well as deaths by drug overdose.

Formerly a proud symbol of working class home-ownership, the Kensington row home has become an architectural testament to the structural violence of postindustrial decline. But a closer look at these houses reveals how street-level operators have re-appropriated the row home as a strategic site for poverty survival. Taken collectively, the efforts of these operators have

1 The book is provisionally entitled "Structure Up! The Political Economy of Prison Based Treatment and Re-entry Programming in Illinois and Chicago" (in preparation [n.d.], University of Chicago Press). 
produced what I am calling the Philadelphia recovery house movement, whereby 400-500 row homes have been transformed into unregulated, unlicensed recovery houses since the early 1980s. Recovery houses have no official licensure or regulatory board in Pennsylvania, and they are run almost entirely by non-professional recovering addicts. With very few exceptions, the houses operate without formal state or city funding. They do so by pooling the resources of impoverished addicts, which historically derived from General Assistance (GA) in the form of cash assistance and food stamps (and secondarily, Supplemental Security Income [SSI]). By pooling these meager resources in a collective strategy for risk management and poverty survival, recovery houses generate sustainable economies that combine food and shelter with a street-level brand of self-help.

Not surprisingly, the recovery house movement has been quite controversial throughout its 30-year history. Politicians, community groups, and the media have referred to the industry as an underground economy ripe for exploitation and fraud. Operators, however, have typically extolled the houses as spaces of hope in ghetto neighborhoods, arguing that they labor for the good of the city without formal funding. This was the folk wisdom I confronted when entering the field: a story of either rogue street hustlers preying on addiction and poverty, or heroic agents of self-help. To challenge these dichotomous framings, I posed a central research question: How have extralegal recovery houses managed not only to survive, but also to burgeon in a seemingly inhospitable landscape over 25 years in postindustrial Philadelphia?

To answer this question and provide a nuanced portrait of the recovery house movement, I conducted two years of participant observation research on the activities necessary to sustain the informal yet highly structured systems of operation, placing particular emphasis on the nature of the houses as viable mechanisms for poor relief. The findings reveal how old and relatively obscure and vestigial welfare formations (such as GA, a form of outdoor relief that in one form or another dates back to the Colonial Poor Laws) inadvertently provide the foundation for urban poverty survival strategies that are new and in urgent need of study. Analyzing welfare state restructure at this scale requires ethnographic precision due to the ways in which GA seeds informal local subsistence economies, with rules that are constantly made and remade by street-level operators

In order to comprehend the persistence of this extralegal welfare economy on a larger scale and to situate my ethnographic case, I traced the relationships between recovery house actors (addicts and operators) and sites such as the public welfare office, the criminal justice system, city government, and 
the community behavioral health system. I conducted key informant interviews with city officials and professionals, including housing inspectors, formal treatment providers, elected officials, and public welfare officials.

Recovery houses are not merely a haven for benevolent self-helpers or unscrupulous actors in the informal economy, but are rather a manifestation of processes stemming from postindustrial decline and welfare reform. Indeed the recovery house movement has been forged at the vortex of several factors - among them a degraded postindustrial landscape, modest pumppriming dollars from a declining welfare state, hollowed out urban institutions (licenses and inspections), and the agency of recovery house operators themselves. I argue that Kensington recovery houses have become sustainable economies by promulgating ways of knowing and acting that are attuned to the contingencies of the social, economic, and welfare politics of the postKeynesian era. My work thus contributes to recent trends in urban studies and the ethnographic study of social policy, whereby informal survival strategies are situated within the context of macro-structural forces and the political economy of cities (see Fairbanks, 2009: 65-98).

Forging ethnographic linkages between the survival mechanisms of poor subjects, meso-level urban institutions, and the state, I illustrate how governmentality operates at two levels in the recovery house movement. One is at the street-level, within the recovery house system itself, which acts as an anti-poverty mechanism through calculated interventions deployed to exact certain desired outcomes in governance - autonomy, sobriety, self-responsibility, good citizenship, surveillance, financial subsistence, and the regulation of bodies through a free market. The fierce competition for bodies and the intense downward pressure on operating costs are transmuted onto recovering subjects, effectively producing a street-level mode of regulation and a complex, historically specific post-welfare poverty management system for the state (see Fairbanks, 2009: 99-188). This leads to a secondary vector of governmentality, which operates between the recovery house movement and the city. The meta-analysis of urban institutions exposes a variegated regime of regulation, tolerance, and indifference among city elites, elucidating the ways that recovery houses have become situated within the fabric of Philadelphia's social service sector as an informal mechanism of the welfare state. Taken together, these factors help to explain the persistence and proliferation of an extralegal and irregular form of housing located conspicuously in Philadelphia's most notorious areas of spatially concentrated poverty (Fairbanks, 2009: 189-260).

The primary contributions of the book are two-fold: first, to illustrate the fall out, or lived realities, of contemporary social policies and urban process- 
es associated with welfare state restructure and postindustrial decline; and second, to illustrate the agonistic reconfiguration and reconstitution of vestigial poverty survival strategies and forms of urban subjectivity in accordance with the reconstructed and rescaled economic and social policies of neoliberalism. In other words, ethnographic data are deployed to illustrate how mechanisms of poverty survival are induced by neoliberal reform, while simultaneously acting as a form of resistance to these trends. Along these lines, the state's variegated responses to recovery houses are shown to not simply enable an informal economy to persist, but in fact these responses deepen urban informality while attenuating and accelerating the capacity of informal actors to function as agents of urban restructuring. The restructuring in question here refers to meso-level institutions such as public welfare and criminal justice, as well as to relationships between citizen and state and the contemporary boundary institutions of the postindustrial city. At the street-level, this occurs within the informal subsistence economies of recovery house markets, which are driven by the many innovations in informal welfare provision and in highly competitive census building projects that illustrate the ways in which operators remake the rules of GA and SSI. Apart from the predatory markets of recovery houses themselves, processes related to "relapse" and the "wreckage of one's past" reveal the ways in which addicts are caught up not only in informal and highly contingent low wage labor markets, but also any number of meso-level disciplinary nets, from child support, to criminal justice, to public welfare. And while these processes pertain to the recovering self, I have also revealed recent citywide efforts to formalize the recovery house as a form of statecraft operating within the compendium of the workfare state and the prison (Fairbanks, 2009: 231-260).

Taking these points together, I have followed Jamie Peck's lead in conceiving of the recovery house system as a highly localized and rhyzomatic regulatory project - a set of interrelated tendencies expressed through chronic unevenness, instability, and insecurity rather than a coherent or achieved post-welfare regulatory end state (see Peck, 2001). Perhaps most importantly, ethnographic research enables us to conceive of the ways in which streetlevel actors respond to, interpret, and manipulate state selectivity and differentiation at the level of conduct. Poverty survival strategies, in this case those that regulate and discipline subjects informally, embody the stakes in political struggles; as local actors in the recovery house movement act through local strongholds (at the street and the urban institutional level), capitalizing on a recovery knowledge that has both parochial and universal appeals to morality and ethics, as well as local economic appeals to subsistence and profiteering. The recovery house operator must build on, complement, and accelerate 
the objectives of a complex set of institutional regulatory logics that in turn facilitate the broader restructuring imperatives of the postindustrial city.

Far from an "unregulated" phenomenon, the recovery house experience ensures a constant negotiability regarding welfare eligibility, probation and parole, child support, low wage employment, security of tenure in informal or invisible housing markets, and even land use. It is this very negotiability that gives birth to a very peculiar and highly contradictory type of poverty management system that operates on the periphery of the workfare state and the criminal justice system. By conceiving of the recovery house as an instrument of poverty management, I mean to denote an informal welfare appendage which functions on the condition of its inhabitants' insecurity in their attempts to manufacture survival. The end result is to churn and manage surplus populations through the performance of recovery with little possibility of mobility or integration into formal labor markets. Far from seeing this as a depoliticization, however, my analysis suggests the ways in which the political production of recovering subjectivity, in formal and informal sites of social service administration, articulates with a number of regulatory restructurings in public welfare and criminal justice.

The recovery house therefore operates as a boundary institution, whereby the city and the state empty out overcrowded jails and prisons through recovery house networks, relying on the system as a kind of pressure valve or floodplain, to manage the crises of mass incarceration in an urban labor economy that simply cannot absorb surplus bodies. Along these lines, my analysis recasts the stakes of recovery well beyond conventional questions of abstinence from drugs and alcohol. It does so by showing how surplus welfare populations in postindustrial cities become bound to a set of recovery practices, rituals, and discourses that come to occupy and entangle idle citizens in zones of spatially concentrated poverty with little hope for upward mobility. The research for my first book has led me to the growing intersection of recovery programming — both formal and informal — on the one hand, and prisoner re-entry on the other. In maintaining this focus, I am operating under the hypothesis that we cannot understand $21^{\text {st }}$ century urbanism or welfare policy without understanding its links to penal policy. At precisely this intersection, we find new imperatives to manage urban marginality in postindustrial cities. 


\section{The Fall Out of Mass Incarceration in Chicago}

The State of Illinois currently incarcerates more than 49,000 inmates on any given day, and upwards of 36,000 of this total number are released each year. Roughly two-thirds (25,000 annually) return to just seven zip codes located on the West and South sides of Chicago, where black male unemployment exceeds $45 \%$ even before ex-felons return home (see Olson and Rozhon, 2011; Peck and Theodore, 2008; see also La Vigne et al., 2004). The numbers involved in these estimates comprise a veritable crisis that has come under the name of prisoner re-entry, a growing policy obsession at the national, state, and urban scale. From George W. Bush's 2008 Second Chance Act, to the 2009 Illinois Crime Reduction Act, to numerous municipal policy and practice initiatives at the Cook County Jail (a massive institution in its own rite, holding 10,000 inmates per day), the re-entry imperative operates across multiple scales and along multiple administrative fronts. It has been fueled by a convergence of disparate ideological positions and the formation of novel political coalitions among policy elites.

A central component of the Illinois re-entry initiative is the Sheridan Correctional Center, a level 4 medium security state prison located 70 miles southwest of Chicago. Billed as the nation's largest and only fully dedicated substance abuse treatment prison (and the only program of its kind that is medium security), the Sheridan Correctional Center is a bold experiment in the history of criminal justice reform. In the state of Illinois' current economic and political crisis, Sheridan has been framed as a hopeful-and potentially replicable - model for changing the way in which the criminal justice system addresses the complicated nexus between addiction, urban poverty, and recidivism. Opened in 2004, Sheridan has been designed and planned with an eye toward the pathways and channels to successful urban reintegration, both in terms of neighborhoods and social service delivery systems.

To date, I have conducted 18 months of ethnographic fieldwork inside the walls at Sheridan Correctional Center (the last ethnographic project to take place inside the walls at an Illinois state prison was for James Jacobs Stateville, published in 1977). My primary aim thus far has been to assess the pervasive significance of treatment on the social ecology of the prison. Whereas historically there have been two codes to live by - that of the guards and the inmates-Sheridan introduces a new historical moment in which a third party (treatment) actively transforms modalities of governance and praxis. However, in this chapter I will not discuss the ethnographic fieldwork inside the prison per se, but rather present parts of the research that put the history of Sheridan in conversation with its broader political economic con- 
text. I will therefore show how Sheridan came into being and then index a series of theoretical and philosophical placeholders for ongoing thinking about what Sheridan means for theories of political economy and welfare state transformation. On both accounts, my analysis is meant to provide an inroad for consideration of how substance abuse treatment works as an ancillary modality of criminal justice to resolve the crises of recidivism, re-entry, prison overcrowding, and prison expenditure. These I contend are the most visible symptoms of the still muscle-bound regulatory framework of mass incarceration, the gradual weakening of which has led to context-specific forms of regulatory experimentation.

To begin with a quick sketch of mass incarceration in the United States, there has been an explosive growth of the U.S. prison system since 1970 that is by now well documented. Statistical overviews are rehearsed with such frequency and alarm that they have an almost numbing effect. Nonetheless, this descriptive rite of passage is important to understand the true magnitude of the prison and its central role in today's political economy of urban poverty, social welfare, and labor stratification. Following a 50-year period (1920-1970) in which the prison population in the United States held relatively constant at 200,000, the incarcerated population in state and federal prisons grew five-fold in three short decades, reaching 1 million persons by 1995 and 1.3 million persons by 2002 (see Harcourt, 2011: 198; Wacquant, 2009: 60-61). If we include those incarcerated in local jails, the number reached 2 million persons by 2002 and is up to more than 2.3 million today. The increase in state and federal prisoners between 1970-1995 alone (from 200,000 to 1 million) represents a $442 \%$ increase in a quarter century, a growth magnitude never before witnessed in a democratic society (see Wacquant, 2009: 61). By 2008 the U.S. was incarcerating more than $1 \%$ of its total population. The US has the highest incarceration rate in the world, five times the rate of England and twelve times the rate of Japan (see Harcourt, 2011:198). With merely $5 \%$ of the world's population, the U.S. now holds nearly $25 \%$ of the world's prisoners (see Gottschalk, 2006: 1). The carceral boom has been anything but colorblind. In four short decades (1970-1990), the racial and ethnic composition of the incarcerated population reversed, from $70 \%$ white, $30 \%$ black and Latino inmates; to $70 \%$ black and Latino, 30\% white inmates (see Wacquant, 2009: 60-61).

While beyond the scope of this paper, suffice it to say that historical explanations for the incarceration boom are broad and diverse, ranging from postindustrial decline, to globalization, to shifts in sentencing, to the war on drugs, to welfare state retrenchment. For the purposes of this chapter I will focus on one particular historical explanation for mass incarceration: the re- 
soundingly new consensus after 1970 that prison works "not as a mechanism of reform or rehabilitation, but as a means of incapacitation that satisfies popular political demands for public safety and harsh retribution" (Garland, 2001: 14). More specifically for my purposes, I am most concerned with the putative eclipse or gutting of rehabilitative frameworks from the 1970's-early 2000's said to act as a mainspring of the warehousing logics of mass incarceration, and their eventual and (perhaps) still quite nascent re-emergence in the contemporary present.

The most extensive exploration of this trend has been undertaken by David Garland $(1985,1993,2001)$, whose books on $20^{\text {th }}$ century criminal justice map the transition from "penal welfarism" (1900-1970) to what many critics have described as a neoliberal turn in punishment policy. In describing the penal welfarist era, Garland sketched the monopoly that clinicians (social workers, psychiatrists, psychologists, even sociologists) once held in the long rehabilitative horizon that dominated life in the prison up until the close of the 1960's. The core assumptions of criminology in the welfare era were premised on a faith in the perfectibility of man. Crime was perceived as the sign of an underachieving socialization process, and society looked to the state and its clinical expertise for social adjustment (see Dilts, 2008; Garland, 2001). Since the late 1960 's, Garland contends, the correctional facility has reduced its rehabilitative ambition to ground zero. Contemporary criminology (1970-2000) views crime as "routine, [and] committed by individuals who are for all intents and purposes normal" (Garland, 2001: 15). Offenders are now envisaged as rational economic actors responsive to disincentives and fully responsible for their actions, leading to a theory and rationality of criminology that strongly reinforces retributive and deterrent policies. Crime is explained no longer on a theory of individual deprivation, but rather as an outgrowth of inadequate controls that can be governed through risk management strategies (see Garland, 2001).

The death of penal welfarism is said to have been accompanied by the disappearance of rehabilitative programming in prisons, which has indeed been eulogized consistently in the literature on prisons since 1970 and also posited as a central component of mass incarceration. By Garland's own admission (2001: 7), we would be wise to take precautions when dealing with broad-brush strokes and historical periodizations. Any complex, multidimensional field undergoing transformation will show signs of continuity and discontinuity as institutionally inherited landscapes are reworked en route to new welfare settlements (see Clarke, 2006; Polanyi, 1944). Nevertheless, and bearing in mind these precautions and rules of methodological good sense, if we take Sheridan as a case study it seems clear that something is happening 
in recent machinations of prison reform in the early $21^{\text {st }}$ century. And my contention here is that we may not quite know yet just what it is. Resolution of the consequences, failures, fallout and crises of mass incarceration have perhaps entered us into a new phase for consideration, and the Illinois version of the carceral boom certainly points us in this direction.

The state of Illinois has experienced its own exceptionally aggressive incarceration boom. The state's prison population doubled from 1973-1982, then doubled again by 1991, and then rose another $55 \%$ by the close of the 1990's (see Peck and Theodore, 2008: 252). Put another way, from fewer than 20,000 inmates prior to 1987 , the Illinois prison population grew to 45,000 by the year 2001 and stands at nearly 50,000 today. To accommodate the population growth, Illinois opened 21 prisons between 1980 and 2004, adding 20,318 beds to the system's statewide capacity of 31,000 . The present population of almost 50,000 inmates speaks conspicuously to the crisis of overcrowding in Illinois (see Olson and Rozhon, 2011: 9).

Originally opened as a juvenile center in 1941, Sheridan changed to an adult prison facility in 1971. After a brief closure between 2002-2004 (due to a budget skirmish under former Illinois Governor Ryan's watch), the Sheridan Correctional Center was re-opened as a fully dedicated substance abuse treatment prison on January 2, 2004 (see Olson and Rozhon, 2011: 13). The newly opened Sheridan prison was engineered to solve the current crises of recidivism and overcrowding through the re-emergence of substance abuse programming for re-entry. Early advocates for Sheridan (notably Deanne Benos, as well as Diane Williams at Safer Foundation and Pam Rodriguez of Treatment Alternatives for Safe Communities [hereafter TASC]) convinced then-Congressman Rod Blagojevich to take a chance on reopening the recently closed Sheridan Correctional Center as the nation's first fully dedicated substance abuse prison. A central impetus at the time was that the Illinois recidivism rate (defined as the number of inmates returned to prison within 3 years of release) had hit record highs of $54.4 \%$ in 2003 and $54.6 \%$ in 2004 . The recidivism rate was even higher-nearly 66 percent - when based on rearrests for a new crime within three years (i.e., regardless of whether it resulted in their subsequent return to prison). With Blagojevich's backing, the early architects of Sheridan researched best practices in those "leading" states with the lowest recidivism rates. They came to focus on substance abuse treatment as the most effective, evidence-based intervention to reduce recidivism and to strengthen reentry programming.

For the prison phase of the process, all bets were placed on the Therapeutic Community model (TC), described by the National Institute on Drug Abuse as residential [programs] using a hierarchical model with treatment 
strategies that reflect increased levels of personal and social responsibility (as cited by Olson and Rozhon, 2011: 13). The TC model depends upon "peer influence, mediated through a variety of group processes [...] used to help individuals learn and assimilate social norms and develop more effective social skills" (Olson and Rozhon, 2011: 13). At Sheridan, this is accomplished through the provision of individual and group treatment, delivered by a contractual service provider known as WestCare Foundation. Inmates also receive a variety of ancillary services, including educational programming, job training, vocational training, anger management classes, parenting skills, and relationship skills. The TC treatment approach is also augmented by a hybrid modality that adjoins Cognitive Behavioral Therapy (CBT), Motivational Interviewing (MI), and 12-step recovery. Treatment takes place all day every day across the Sheridan compound, which is comprised of 25 separate housing units (mostly single story "x houses" or "k houses," although two of the larger housing units contain two stories). Within each housing unit at Sheridan, the population is divided into several (usually four) therapeutic communities or "families."

The development and planning of Sheridan articulates with three national trends driving the contemporary debates in prison reform: cost effectiveness, recidivism/reentry, and recovery. Let me address each of these trends briefly.

First, we are witnessing a crisis in the rising costs of incarceration, made even more acute by the financial collapse of 2008 and its associated fiscal austerity mandates. Federal and state spending has grown exponentially since 1972-Illinois currently spends $\$ 1.5$ billion per year on corrections out of a state budget of $\$ 25$ billion. In the wake of unprecedented expenditures, the fiscal crisis of 2008 has produced strange political bedfellows from a range of ideological backgrounds - Christian fundamentalists, prisoner's rights advocates, political progressives, libertarians and fiscal conservatives - are now in agreement that the exorbitantly expensive carceral state build up of the last 40 years is no longer tenable. These nascent coalitions also seem to be in some agreement that they have to spend money to save money, at least selectively.

Second, and accordingly, we have seen an increase in public and political attention to the costly problems of recidivism/overcrowding, and a concomitant imperative for prisoner re-entry programming at the federal (e.g. George W. Bush's 2008 Second Chance Act), state (e.g. the Sheridan Correctional Center, as well as the 2009 Illinois Crime Reduction Act that includes sentencing reform, the Risks Assets and Needs Assessment task force [RANA], and Adult Illinois Redeploy) and municipal levels (e.g. the Cook County Collaborative on Re-entry, which includes numerous Green initiatives in envi- 
ronmental programming; in addition to myriad innovative efforts in Cook County Jail such as Division 17 transgender programming).

Third, we have seen proliferation of substance abuse treatment models to address the prison crisis. The growing intersection in policy and practice between criminal justice, substance abuse recovery, and urban social welfare has catalyzed a new wave of treatment models deployed in prison administration, probation and parole programming, and housing/re-entry programming for ex-offenders. Most parties now agree that the austere, tough on crime approach of providing inmates with a mere $\$ 50$ in gate money for a bus ride back to Chicago is simply too costly for the region. A social service bridge is necessary for reintegration. Suddenly, rehabilitation is back.

\section{The Return of Rehabilitative Frameworks in the Double Movement}

A central objective of this chapter is to show how drug and alcohol recovery-from its most informal inception in the self-help realm of Philadelphia recovery houses to its most formal and monolithic in state prison and paroling practices - works as an ancillary modality of poverty management to resolve the current crises of mass incarceration and to reinvent urban welfare practices in the $21^{\text {st }}$ century. In this regard, rehabilitative programming operates across administrative sites and scales in contextually specific forms that are nonetheless logically consistent in their path dependent regulatory effects. For example, at the heart of my Sheridan study lies a very tentative hypothesis that we may have entered a new, "third" period in the history of prison reform. The current trend at least partially harkens back to the rehabilitative era of penal welfarism from 1900-1970 (although it should be noted that there are no attempts to rehabilitate all prisoners, and the supermax prison is still very much intact). But in order to truly understand the historical question: Why Sheridan? Why now? We must put the correctional center in a much broader light; to show how it resonates and articulates with the larger political and economic arrangements of post-welfarism. Let me conclude by offering a few provisional explanations for the Sheridan prison's persistenceeven at 43 grand a bed as against 23-in an era of near-unprecedented fiscal austerity; I am therefore asking not only why the treatment prison emerges in 2004, but also and perhaps more importantly: why does it survive?

My first explanatory remark relies heavily on Loic Wacquant's notion of prisoner reentry as myth and ceremony (Wacquant, 2010: 613). In essence, Wacquant draws from Weber, Durkheim and Bourdieu to illustrate how the 
praxis of re-entry itself becomes a practice or habitus. As seven in ten convicts coming out of prison are re-arrested and over half are re-incarcerated within three years, it becomes readily apparent that the concept of reintegration is in fact a misnomer at best. Wacquant's persistent point is that these men were never "integrated" to begin with as there has never been a structure to absorb and accommodate them on the outside.

My research findings to date in fact reveal three ways of "doing re-entry" in Chicago, none of which are very promising for the notion of "pathways to re-integration." The first is to find formal employment in the low wage service sector. While not impossible, for the better part of the men I am studying this option is dead on arrival based on the presence of $50 \%$ black male unemployment in the neighborhoods to which they return. The second strategy is to get involved in a kind of entrepreneur training program, wherein providers offer a 12-15 week "mini-MBA" course on the assumption that most convicts are natural born capitalists, or "risk takers" with an aversion to central authority and a committed aspiration to working for themselves. At the completion of the program, which entails writing a "fundable" business plan, exoffenders can qualify for low interest start up loans in order to convert their entrepreneurial dreams into actual businesses. We can call this trajectory a "Stringer Bell" modality of re-entry, whereby the convict merely needs to learn how to code switch and acquire the requisite social, cultural, and literal capital to learn how to hustle on the legitimate side of the economy ${ }^{2}$. The third and more common channel of re-entry, and the one I will focus on for the remainder of this chapter, is to enter into recovery through the many state sponsored avenues of practicing sobriety and self-transformation. In essence the ex offender becomes a recovering addict in perpetuity, and recovery itself becomes something of a job. In addition to the rigorous activity of maintaining their own sobriety, many ex offenders try to become para-professional counselors, motivational speakers in programs such as "scared straight" that send ex gang bangers into high schools, or residential case managers in the very houses to which they returned upon release from prison. Others hang around programs and politicians in hopes of somehow coming into contact with trickle down stimulus dollars, which might allow them to get into social service programming in the re-entry field. In this regard addiction has come to be seen as a problem in and of itself-quite distinct from actual crime and

2 Here I am referring to the character Stringer Bell from David Simon's acclaimed HBO series The Wire. Bell is portrayed as a civilized and civilizing force (against his partner Avon Barksdale's more primitive gang violence and tendencies toward warfare and barbarism) in his attempts to adopt corporate practices, implement Robert's Rules of Order, and code switch as a businessman in the city's deeply politicized real estate circles in order to claim legitimacy as well as new forms of social and cultural capital. 
victimization - and with its fashionable emergence recovery has become part of a broader compendium of distinctive policies and practices developed to reduce recidivism without much promise of reintegration to meaningful employment.

In many respects, re-entry through recovery entails something more of a trans-institutionalization rather than a de-carceration per se. In this sense recovery comes to embody what Lauren Berlant (2011) refers to as a cruel optimism: the affective structure associated with increasing precarity in the face of waning sovereignty and dissolving assurances. Berlant contends that amidst the fraying of contemporary fantasies - of upward mobility, job security, gainful employment even-recovery becomes somewhat doubly cruel insofar as it entails being inside a relation that becomes sustaining regardless of the content of the relation. Recovery for the ex-offender entails becoming bound to a set of practices, rituals, and discourses that simultaneously come to churn the subject in regulatory eddies at the same time that the recovery narrative becomes profoundly confirming.

In light of these reflections, what I like to suggest in conclusion to this chapter is that re-entry is currently operating as a new form of political patronage and a new form of what Karl Polanyi (1944: 150) famously referred to as the "double movement." I will provisionally contend therefore that at least in part, what has come to replace the streets and sanitation jobs of public works clientalism in the Chicago of old is a form of social service patronage in the double movement. To make this point let me briefly invoke Polanyi's central thesis. Polanyi contended that market liberalism evolved into a veritable faith in man's secular salvation via the self-regulating market, or laissez faire. He turned the notion of laissez faire on its head, however, with his concept of the double movement, insisting that disembedding the economy from social relationships and political institutions necessarily entails an ongoing role for the state in the management and regulation of society via social protection in pre-capitalist (or extra capitalist) forms of aid and decommodification. By illustrating how the role of the state is to be found, empirically, in welfare measures seeking to alter, regulate, or slow the rate of change, Polanyi's study gave birth to a long welfare analytical tradition in regulation theory and political economy.

In my own case, resurrecting Polanyi's thesis for refinement of the fashionable term "post-welfarism" entails thinking critically about what Bernard Harcourt (2011: 40-44) has termed "neoliberal penality." As Harcourt argues in his indictment of the Chicago School, the tension of neoliberal penality lies in what several have referred to as the cost of our current political and economic arrangements: the price we pay for our unyielding belief in the 
economy as the realm of natural orderliness (dating back to the Physiocrats) and the concomitant belief that the legitimate and competent sphere of government lies in policing (see Harcourt, 2011). For Harcourt the steep price of neoliberal penality lies in the following two consequences. First, we naturalize the myriad existing regulatory mechanisms in contemporary markets, thereby obfuscating the distributional consequences of these very mechanisms. Second, we resort to mass incarceration as the quintessentially legitimate form of state building. Harcourt documents how this messianic belief bestows upon a series of thinkers, from Adam Smith to von Hayek, from Bentham to Gary Becker, the task of establishing a theory and philosophy of punishment for classical liberals and their neoliberal counterparts (see Harcourt, 2011: 121-150).

Ultimately, Harcourt illustrates how the final task of articulating this theory of punishment fell on Richard Posner and Richard Epstein, who converged on a similar view of political economy and punishment that was institutionalized in the Chicago School of Law and Economics. As Harcourt shows, this vision replicates the curious alchemy of orderliness in the economic sphere, and state intervention/competence in the penal sphere. Consider for example Posner's definition:

The major function of criminal law in a capitalist society is to prevent people from bypassing the system of voluntary, compensated exchange- the "market," explicit or implicit—in situations where, because transaction costs are low, the market is, virtually by definition, the most efficient method of allocating resources. Attempts to bypass the market will therefore be discouraged by a legal system bent on promoting efficiency. (Posner, 1985; as cited by Harcourt, 2011: 138)

For Posner then, what becomes forbidden is a class of "inefficient acts" that include not just market bypassing in the case of stolen goods that could have been otherwise purchased, but also the market for labor (see Harcourt, 2011: 136). In other words, crime represents an express bypassing of the traditional means of obtaining money, i.e. gainful employment.

While I am largely in agreement with Harcourt's impeccable indictment of the Chicago School of Law and Economics as well as his overall attempt at theorizing neoliberal penalty, I am concerned with the tendency here ${ }^{3}$ to conceive of the state in an over-determined or monolithic light. I want to argue in contrast that welfare state transformation is more nuanced, and that the contradictions of neoliberal penality actually open the door for another type of state building that cannot best be described as the iron fist in the velvet glove. I am ultimately interested here in a softer and gentler side of political 
development locatable in the partial decay or at the very least fraying of the regulatory framework of mass incarceration. This can only be found in the realm of welfare professionals and the social service delivery matrices of cities. Urban Poverty and its associated regulatory problems emerge cyclically in public life as issues to be solved. Market liberalism typically contradicts itself in the sense that it is repeatedly forced to rely on pre-capitalist institutions unable to play the market game due to burdens of social responsibility (churches, family, prisons, social work) (see Polanyi, 1944; Esping-Andersen, 1990: 37). And while this conundrum is a recurring theme in history, as Jamie Peck (2001: 38) shows there may always be echoes and tendencies, but history never repeats itself.

Poverty governance can never be fixed, and it must always keep time with the rhythms of political life and the economic imperatives of late capital (Soss, Fording and Schram, 2011).

It is here that I want to locate the Sheridan Correctional center as well as the Philadelphia recovery house movement. In the marketless re-entry sphere, whereby statebuilding occurs in the realm of monitoring subjects awash in jobless economic recoveries and the speculative bubbles of post-fordist financialization, politics in the double movement brings welfarism back in. Context specific forms of regulatory experimentation are critical forms of urban political development that contain elements of continuity and novelty with the history and philosophy of welfare arrangements. My contention here is that these forms of state building are often overlooked and in urgent need of study. As Garland intimates (2001), they relate to an expanded infrastructure of re-entry, crime prevention and community safety-preventative partnerships, safer cities programs, Business Improvement Districts (BIDS) neighborhood watch, all strange bedfellows oriented toward new urban objectives and priorities such as security, prevention, harm reduction, fear reduction. These mechanisms are all low key boutique programs, efforts to build up the control of neighborhoods largely through the patronage and clientalist logic of recovery programming.

In this regard, my ultimate goal in this chapter has been to suggest the ways in which the state is managing the urban crisis against a wave of fiscal austerity. I have sought to provide an inroad for consideration of how substance abuse treatment works as an ancillary modality of criminal justice to resolve urban crises of surplus labor populations as well as institutional crisis of recidivism, re-entry, and overcrowding as the most visible forms of crisis in the regulatory framework of mass incarceration. This crisis has led to context specific forms of planned and unplanned experimentation such as recovery houses and prisoner re-entry programming. 
As Esping-Andersen stated long ago, it is in the quality and arrangement of social rights, not in their existence per se, that we can identify a distinct welfare approach (1990). Dimensions of variation should be empirically identifiable not necessarily by expenditures alone or by the efficacy of treatment interventions per se (i.e. "what works," intervention x produces outcome y), but rather via analysis of rules and standards, eligibilities, restrictions, and so forth; and perhaps more importantly via analysis of the lived experience of social policy and practice interventions. In each dimension, the welfare state is a continuously stratifying institution and an active force in the ordering of social relations (Esping-Andersen, 1990). But we would be remiss to believe that these stratifying dimensions would have any degree of functionality in historical transformation if they were immutable.

Across my projects, my goal is to discern the significance of contemporary welfare state transformation for marginalized groups and the political economy of cities. I believe this type of analysis is necessary to help social workers, policy makers, and social scientists better specify the political possibilities available to reduce inequality and to better assess how the restructurings of postindustrial urbanism increasingly marginalize the poor. In the case of recovery programing - formal in prisons, informal in recovery houses - we begin to see how governmental agendas of austerity and devolution are at least partially facilitated by offloading responsibility to the poor through ethical registers of emancipation and empowerment. Efforts to harness and shore up human potential should be augmented by a reconsideration of redistributive urban policies. My findings suggest that social work practitioners take a broader view of recovery and empowerment strategies as important supplements but not as panaceas. Hearkening to the profession's long tradition of systemic contextualization and social justice, my findings show how recovery practices can ring hollow in the new economy and can even facilitate a pernicious reworking of institutional arrangements in postindustrial capitalism.

\section{References}

Berlant L (2011) Cruel Optimism. Durham NC: Duke University Press.

Clarke J (2004) Changing Welfare, Changing States: New Directions in Social Policy. London: SAGE.

Dilts A (2008) Michel Foucault Meets Gary Becker: Criminality Beyond Discipline and Punish. Carceral Notebooks 4: 77-100.

Esping-Andersen G (1990) The Three Worlds of Welfare Capitalism. Princeton: Princeton University Press.

Fairbanks II RP (2009) How It Works: Recovering Citizens in Post-Welfare Philadelphia. Chicago and London: University of Chicago Press. 
Garland D (2001) The Culture of Control: Crime and Social Order in Contemporary Society. Chicago: University of Chicago Press.

Garland D (1993) Punishment and Modern Society: A Study in Social Theory. Chicago: University of Chicago Press.

Garland D (1985) Punishment and Social Welfare: A History of Penal Strategies. Aldershot: Gower.

Gottschalk M (2006) The Prison and the Gallows: The Politics of Mass Incarceration in America. Cambridge, UK: Cambridge University Press.

Harcourt B (2011) The Illusion of Free Markets: Punishment and the Myth of Natural Order. Boston: Harvard University Press.

Jacobs JB (1977) Stateville: The Penitentiary in Mass Society. Chicago: University of Chicago Press.

Olson DE and Rozhon J (2011) A Process and Impact Evaluation of the Sheridan Correctional Center Therapeutic Community Program During Fiscal Years 2004 Through 2010. Unpublished report. Loyola University Department of Criminal Justice on behalf of the Illinois Department of Corrections.

Peck J (2001) Workfare States. London: Guilford Press.

Peck J and Theodore N (2008) Carceral Chicago: Making the Ex-offender Employability Crisis. International Journal of Urban and Regional Research 32 (2): 251-281.

Polanyi K (1944) The Great Transformation: The Political and Economic Origins of Our Time. Boston: Beacon Press.

Soss J, Fording R, and Schram S (2011) Disciplining the Poor: Neoliberal Paternalism and the Persistence of Race. Chicago: University of Chicago Press.

Wacquant LJ (2009) Punishing the Poor: The Neoliberal Governance of Social Insecurity. Durham NC: Duke University Press.

Wacquant LJ (2011) Prisoner Reentry as Myth and Ceremony. Dialectical Anthropology 34 (4): 605-620.

Wacquant, LJ (2001) Deadly Symbiosis: When Ghetto and Prison Meet and Mesh. In: Garland D (ed) Mass imprisonment in the United States. London: Sage, 95-133. 


\section{Philipp Sandermann}

\section{The German Welfare System and the Continuity of Change $^{1}$}

The German welfare system is currently in the midst of a far-reaching historical transformation. While this fact is now widely acknowledged within the scholarly discourse of social work, the extent of the transformation and its precise characteristics continue to be the subject of much debate.

A possible explanation for this may be that the scholarly debate on social work still - after more than a century of disciplinary development- takes little account of one essential reference point for the theoretical analysis of change: the notion of continuity. Yet a sophisticated discussion of change requires an equally sophisticated idea of what remains the same across variations, what remains permanent within the process of change. Only in this way will the phenomenon of change become accessible to understanding. In concrete terms, if we want to talk about change in social work, we need a theory of social work that takes up an analytical stance allowing it to define what social work "is," and to do so across variation until the point is reached when it no longer seems analytically appropriate to continue calling the phenomenon under examination "social work."

Looking at current German-language scholarly discourse on social work through the prism of this theoretical assumption (on which, more generally, see Luhmann, 1986: 180), a dual picture emerges. On the one hand, we find highly differentiated, multifaceted diagnoses of the contemporary social environment that seek to describe "change in the welfare state," "change in social work," "change in child welfare services," and so on. On the other, these debates largely lack embedment in a clear theoretical delimitation of what actually, in structural terms, constitutes a "welfare state," "social work," "welfare practice" et cetera.

In the following, I first present this problem through the example of recent debates on what is in German termed Post-Wohlfahrtsstaatlichkeit, literally "post-welfare statism"; I then outline an approach of my own. That ap-

1 This article is a revised version of a paper originally published in German (Sandermann, 2010). The English translation is by Kate Sturge. 
proach proposes to critically examine important questions around change in social work that are currently being discussed under the heading of "PostWohlfahrtsstaatlichkeit." At the same time, it specifically brings together the factors of change and continuity in a single approach to describing the current state of the German welfare system.

\section{Change Without Continuity? "Post- Wohlfahrtsstaatlichkeit"}

In German-speaking scholarship on social work, "Post-Wohlfahrtsstaatlichkeit" is currently widespread as an analytical label attempting to capture the present phase of the welfare system. Several authors may be credited with having taken up the difficult analytical task of identifying the contemporary transformation of the welfare system (see, e.g., Lutz and Ziegler, 2005; Bütow, Chassé and Hirt, 2008; Kessl and Otto, 2008a; Heite, 2010; Kessl, 2009; ; Lutz, 2010; Oelkers and Richter, 2010). Evidently drawing on the concept of "post-welfarism" taken from the Anglophone debate (see, e.g., Hancock and Sjoberg, 1972; Gewirtz, 2002), the German term "Post-Wohlfahrtsstaatlichkeit" is used to signal a radical change. With more or less obvious recourse to the poststructuralist arguments of Michel Foucault, it is generally assumed that the current change in the welfare system represents a recalibration of individual and collective interests and of the influence of the market and the state (see Kessl and Otto, 2008b: 9).

We may accept these assumptions on principle. Closer scrutiny reveals, however, that the analytical findings-largely generated using Foucauldian analytical instruments - remain vague. This is especially true for the relationship between continuity and change in such models, as problematized at the start of this paper. The difficulty of specifying that relationship by means of the analytical methods adopted becomes clear at several different points. In my view, it arises primarily from the fact that although such analyses, deploying Foucauldian tools and the concept of "Post-Wohlfahrtsstaatlichkeit," enable a relatively thick description of what is changing, they face the problem that these frameworks offer neither the means to develop explanations of why it is changing nor insights into the exact structural logic of the changes described. This is because they fail to include an explicit definition of the unchanging component within change (see, e.g., Kessl and Otto, 2008b: 10). A related problem is that analyses adopting these instruments find it very difficult to work out prognoses that would help us understand how the welfare system may develop in future. 
The diagnosis of "Post-Wohlfahrtsstaatlichkeit" thus remains stuck, so to speak, at a stage where it provides striking social comment, but is somewhat shaky in analytical terms. This is underlined by the frequently blurred use of the label "Post-Wohlfahrtsstaatlichkeit" in at least two senses at once: the prefix "post-" appears sometimes to modify primarily the idea of the state, at others primarily the idea of welfare. In other words, "Post-Wohlfahrtsstaatlichkeit" can be deployed on the one hand to address a "post-welfarist state," on the other as a circumlocution for "post-state welfare." There is clearly an important distinction to be made between these two possible usages, yet it has received almost no attention thus far (for a critical view of the Anglophone debate, see Clarke in this volume and, in outline, Clarke, 2004: 49).

To put what I have said in more positive terms, if the idea of "PostWohlfahrtsstaatlichkeit" is an effective way of generating commentary on the contemporary environment, that effectiveness lies in the term's very openness, its capacity to tentatively embrace both the notion of post-state welfarism and that of the post-welfarist state. Seen this way, there is clearly some value in the talk of "Post-Wohlfahrtsstaatlichkeit" as a transitional formula in such commentary; my aim here is certainly not to discredit that. At the same time, however, constant use of the term "Post-Wohlfahrtsstaatlichkeit" in the scholarly discussion creates considerable analytical problems - once again, precisely because of its openness. Generally speaking, these problems lie first of all in the fact that the label's inexactitude can be used to suggest, at least implicitly, a radical counterreality to an earlier ("welfarist" or "welfarestatist") welfare system. This implication is directed at both state and welfare, generating a degree of synergy. As a result, and despite its reflexive and attenuated application by some authors (e.g., Kessl and Otto, 2008b: 7; Ziegler, 2008: 160-161), the label frequently obscures the fact that at present, based on the empirical evidence available, there is no reason to expect the end or a substantial weakening of the Western, even just the German, welfare system-either in the domain of state influence or in that of social policy and social work services. I would like to sketch out certain concerns around this point, countering the notions both of a currently emerging "post-state welfarism" and a developing "post-welfarist state."

\section{$1.1 \quad$ Post-state Welfarism?}

To begin with the idea of "post-state welfarism," in Germany today there is certainly a change in the weighting of control instruments within the welfare system. This can be seen, for example, in decentralizing tendencies and an increasing move toward pedagogization, under the new slogan of "activation." However, this shift cannot be simply equated with a general withdraw- 
al of the state from the welfare system. The model of the "activating state" and the forms of its realization must not be conflated with notions of a "lean" or even "weak" state (see Olk, 2011: 422). The legal provisions of the German Social Code, Book II (SGB II), in force since 2005, offer a striking case in point. ${ }^{2}$ They suggest that the contrary is the case: the "activating state" is a strong, even authoritarian state that intervenes very actively in the domain of welfare production and may use sanctions to force its addressees into social integration by means of work. ${ }^{3}$

The diagnosis that regards "Post-Wohlfahrtsstaatlichkeit" as a new welfare without the state thus falls short, in particular because it pays too little regard to the role of the state within the entirety of the welfare system's processes - a role that remains quite as salient as before. Further doubt is cast on the hypothesis of an increasingly destatized welfare system when we turn to more quantitative data. For example, looking at social expenditure ratios in the past forty-five years, no sudden change can be observed in the 1970s or 1990s (for critical remarks on this point in the UK setting, see Clarke in this volume). Rather, although the phase beginning in the 1970s, commonly categorized as the era of "Post-Wohlfahrtsstaatlichkeit" (see, e.g., Kessl, 2009), is marked by multiple dips and rises in the social expenditure ratio, since 1972 that ratio has always been higher than it was in the late 1960s and before; in 2008, it was approximately the same as the ratio in years as divergent as 1976, 1982, and 1994 (see Bundesministerium für Arbeit und Soziales, 2008). The overall number of people working for the German welfare system certainly has not experienced a sudden decline (see Züchner, 2007: 213214), and neither has the number of direct state employees among them.

In other words, there is far less empirical evidence than it might at first appear for the general thesis-implicit in the label "Post-Wohlfahrtsstaatlichkeit" - of a novel "destatization" of the welfare system in Germany. But what about the second possible reading of the term? Is it not the case that since the programmatic shift to an "activating state," a kind of state may be observed that, despite projecting a continued claim to provide welfare and integration, no longer delivers genuine integration but instead merely dictates integration to its addressees without regard for non-individual, resource-

2 Book II of the Social Code (Sozialgesetzbuch II) is a key component of the "Hartz IV" reforms to German social security (for a succinct survey, see Kemmerling and Bruttel, 2006).

3 In this sense, I would also dispute the claim that the welfare state's orientation on paid employment is being increasingly queried within the current turn toward a "post-welfare state" (see Kessl and Otto, 2008b: 13). Although this may appear to be the case in view of the continuing debates around civil society, the provisions set out in 2005 in the SGB II legislation crassly contradict it. The German welfare system's traditional focus on paid employment actually seems if anything to have intensified, both in legislation and in the practices of its implementation (see, e.g., Sandermann, Urban and Schruth, 2007). 
based barriers to integration? Might this not quite rightly be thought of as a kind of "post-welfarist state"?

\subsection{A Post-welfarist State?}

When we turn to this second argumentational variant of "Post-Wohlfahrtsstaatlichkeit," particular epistemological pitfalls come into play. They take the shape primarily of normative notions of "real" or "appropriate" welfare: the hypothesis of post-welfarism clearly rests upon a normative idea, usually unspoken, of "real welfare" as the necessary basis for a diagnosis of "nonreal welfare," or, precisely, "post-welfare." A similar point can be made regarding the idea of a "semiwelfare state" (Katz, 1996: 115), which has gained ground mainly in the United States, although Katz's idea of "real welfare" evidently arises from a comparison with continental European welfare systems rather than from the implicit notion of a decline in values.

The normative character of this argument does not in itself constitute an analytical problem - or not as long as the idea of "real welfare" is set out explicitly as being a normative argument. However, if the normative argument is simultaneously to be used to assert a radical historical rupture in the logic of Western welfare systems, more is required than a purely normative construction of "real welfare." "Real welfare" must not only be assertible in normative terms; it must also be assumed to have actually existed in a phase of the welfare system, historically precedent to today's phase, and to that end must be framed in ontological patterns of argument. Specifically, to be able to posit "Post-Wohlfahrtsstaatlichkeit" not merely in the sense of a normative decline in values, but also in the sense of a historical decline in welfare, we must start from the assumption that "Wohlfahrtsstaatlichkeit" once existed as an actual redeemability of the promises of welfare. In other words, we will need to construct a historical perspective in which the welfare system that was programmed along Fordist and Keynesian lines in the 1960s and 70s actually did, at that time, function in accordance with its public claims for itself. To assume this means presuming that the welfare system actively socially reintegrated its addressees in the 1960s and 70s and, in contrast, that it no longer does so today. Sure enough, this assumption-sometimes implicit, sometimes explicit — can be identified in the current German-language discourse around "Post-Wohlfahrtsstaatlichkeit" (see, e.g., Oelkers, 2008: 77).

Upon closer scrutiny, the claim that before the advent of the new doctrine of the "activating state," the German welfare system was actually functioning to deliver "welfare" as it is construed today proves to be a theoretical assumption that - while it may be politically expedient from the point of view of the German social work profession-must be considered rather dysfunctional in 
analytical terms. A review of the available empirical data on the German welfare system that was once doctrinally framed in Fordist and Keynesian terms most certainly does not yield unambiguous evidence that the welfare system of the time structurally effected greater reinclusion, in contrast with a lesser reinclusion in the present day (for more detail, see section 2). Without such findings, it seems theoretically audacious, in the "post-welfarist state" variant of the argument as well, to describe the situation facing German social work today as a historical phase of "Post-Wohlfahrtsstaatlichkeit." If it became more established, this diagnosis could easily lead to a kind of structural "hindsight bias" within the disciplinary debate on social work: retrospectively, what is past appears "more real" and thus, in normative terms, often also more humane, more fit for purpose, more valuable than what obtains today. Interestingly - and this is particularly perplexing for the careful observer - in the scholarly debate of the present, the Fordist-Keynesian welfare system appears as more valuable than it did in the scholarly debate in the era when the Fordist-Keynesian welfare doctrine historically prevailed. This becomes especially striking when present-day descriptions of that doctrine are compared with the academic discourse of the 1970s and 80s on the topic (for more on this, see Sandermann, 2009: 163-198).

This analytical discrepancy within many present-day diagnoses may arise partly from the fact that current retrospective analyses of the FordistKeynesian welfare system tend to be based less on the level of practice and the empirical realities produced by the system than on the purported, or selfdeclared, model of the Fordist-Keynesian welfare system. ${ }^{4}$ One crucial reason for this is doubtlessly the extreme sparsity of empirical data on the practical realities of the welfare system of the period. Yet this lack of evidence does not justify grounding an analysis on the doctrine that prevailed at the time, assuming its validity and setting it against the effects observed or feared today in the implementation of the new doctrine of the "activating state." This amounts to comparing a program in the past with the effects of a program in the present day, instead of carrying out a comparison consistently on the same plane. In effect, it results in the Fordist-Keynesian welfare system being perceived as "real" social work in a "real" welfare state that always kept its promises, whereas today's system is interpreted as a merely superficial welfare state from whose scope contemporary social work is increasingly excluded.

4 Clearly, the discrepancy is not limited to those portraits of the era that use the term PostWohlfahrtsstaatlichkeit; it is also found, for example, in the notion of a "neo-social" welfare (see, e.g., Kessl, 2006; Lessenich, 2011). It is widespread, and as such is relevant to the scholarly study of welfare. 


\section{The Federal Republic of Germany's Welfare System: A Theoretical Model Inspired by Systems Theory}

The blurred edges I have described in contemporary diagnoses of change in social work and the welfare state pose an especially serious analytical problem for scholarship in those cases where, in the course of a surely valuable and thick description of the details of that change, they threaten to obscure something that is equally vital to a systematic study of the German welfare system's current transformation: the continuities within the process of change.

In the following, therefore, I outline a model that offers a corrective based on a critical reading of the debate, ${ }^{5}$ seeking to trace in particular the continuing function of the welfare system within social change. For the reasons given above, my analysis consciously avoids a purely poststructuralist approach, instead working with some fundamental assumptions of systems theory. It builds upon two premises in particular. The first is the need to maintain a "candidly disinterested" approach to the object of the study during observation (Neumann and Sandermann, 2007: 14); the second is the need to distinguish between the values and the functions of the German welfare system.

Observing the German welfare system with candid disinterest means objectifying it outside of any professionally motivated commitment to its existing practices. Only in this way can we create spaces for a critical interpretation of functional relationships between the practice of social work and its societal relationality, spaces that open up in various different directions. Here, social work is regarded not as a "downstream," reactive part of society, but as an active part of the coproduction of social practice (see Blank, 2004: 41; more generally also Brodkin, 2009; for Germany Sandermann et al., 2011; with an early international impact Lipsky, 1980).

Distinguishing between the system's "value ideas" and its functions means consistently interpreting the German welfare system's own claims to produce "social justice," "social equality," "equal social opportunities," etc., as contingent value ideas and not as functions of the system. In turn, this means that these value ideas, usually deployed as promises of integration, are neither accepted as "true" nor discredited as "untrue." Instead, they can be described as ideas, in a critical and distanced observation, and distinguished from the functions of the German welfare system as deduced from a systemstheoretical perspective. It is then possible to analytically explore the relation- 
ship between changing value ideas and the continuing functions of the system.

In order to analyze the relation between value ideas and functions in the German welfare system in this way, however, it is necessary first to open up discursive access to the phenomenon of the "German welfare system" itself. To this end, I will present the academic debate, now quite differentiated, around the German welfare system's genesis and dynamics, aiming to develop an explicit analytical notion of what it might mean to speak of such a system (see also Sandermann, 2009: 128-142). It is only through a reflexive, theoretical model of this kind that comprehensive analytical scrutiny of continuity and change in current developments will be possible.

\subsection{System, Guiding Distinction, and Change in the Value Ideas of the Welfare System}

Research into the welfare state has been a distinct branch of research for around sixty years now (see Leisering, 2001: 1214), so in order to analyze the phenomenon "welfare system" it is initially important to get a grip on the discursive field of welfare state research. Yet even the definition of the debate calls for terminological differentiation. Within the existing literature very different terms are used, sometimes quite unsystematically, to describe what is more or less seen as the same thing. In fact, however, it would seem important to keep rigorously to a single term. In the following, I use "German welfare system," which avoids implying an orientation on state and politics but nevertheless retains a historically specific reference to the model of postwar Germany. I specifically favor this term over "welfare state," 6 and intentionally focus on the German case since international comparisons continue

6 Stephan Lessenich (2000: 41) presents very fair arguments in favor of using the term "welfare state." A key advantage is that it names a specific mode of politically implemented sociation, a historically specific type of society that may be regarded as a postwar phenomenon of Western societies and is historically anchored in the period since the 1950 s (ibid.). However, it remains dubious whether the term's focus on statehood really does justice to the social phenomenon that it names (for a critical account, see Willke, 1989a). Especially for a study that expressly sets out to integrate the societal project of social work into the social phenomenon at stake here, the term "welfare state" appears unsatisfactory: if we want to include social work at least as a part of what we are describing, then we cannot speak of a clearly state phenomenon - even if statehood is intended only in an institutionalist sense, based on "political structures." Furthermore, the German welfare system is by no means fully steered by the state, but is structured on principles of subsidiarity right down to the domain of social insurance (see also Kaufmann, 2012a). As a result, there are good reasons, in terms of social theory, to locate welfare beyond organizational mechanisms that emanate directly from the state (see, from various different perspectives, Leisering, 2005: 120; Bode, 2006: 346-347; Lampert and Althammer, 2007: 11-12; Hegelich and Meyer, 2009; Schmid, 2010: 42-45). 
to show substantial differences between different welfare practices (see the contributions in this volume).

To the extent that a distinct reality (Leisering, 2004: 20; see also, e.g., Lamping and Schridde, 2004: 60; Leisering, 2005: 200; in part Achinger, 1958: 51; Luhmann, 1990: 26) of the German communicative context on the theme of welfare has now been identified, the concept of system seems useful here. If we understand the term "system" in strictly systems-theoretical terms, as designating a relatively closed communicative context in the sense of a distinct logic (see Stichweh, 2000), without resorting to a search for control instruments obviously exclusive to the welfare system, then it is perfectly justifiable to speak of a "welfare system" in the narrow, systems-theoretical sense - even if Luhmann himself never adopted this perspective (though see the "second generation" of sociological systems theorists following him: Willke, 1989b: 113-114; Willke, 1993: 93-94; Leisering, 2005: 259; Stichweh, 2005: 164-165; and more explicitly Kuchler, 2006: 13-15).

From this point of view, it seems possible to offer a reasonably unambiguous answer to the question (crucial to systems theory) of the respective system's basic or guiding distinction (Leitdifferenz) and hence to the question of what "occasions" the distinct reality of the German welfare system that is described by Leisering and other authors. As the occasion for the welfare system's communication we may identify continuing issues around the societal inclusion or exclusion of individuals and groups in modern social contexts (see Luhmann, 1998: 633-634; Bommes and Koch, 2004: 80; Scherr, 2004: 66-67). Accordingly, the guiding distinction of the welfare system in general might be defined as "societal inclusion/exclusion.",

This hypothetical definition of the guiding distinction in systemstheoretical terms provides an initial outline of the German welfare system's system-environment relationship. At the same time, it gives a first, approximate idea of the kind of "irritations" or perturbations to which the system is communicatively receptive, in other words which stimuli have a certain chance of entering the welfare system's communicative circuit. These are stimuli whose direct connection with the guiding distinction of societal inclusion/exclusion is discernible for the system and that also resonate with an internal need for change within the system, that is, which fall on receptive ground.

7 In systems theory, there can be no complete societal inclusion or exclusion of individuals, but only inclusion or exclusion with respect to a particular part of society. Thus, the guiding distinction of the welfare system would be more precisely defined as that of inclusion into/exclusion from parts of society. Conversely, this shows that, in a systems-theoretical reading, a welfare system can potentially declare itself responsible for everything - since there are always inclusions and exclusions in parts of society. 
However, the guiding distinction of societal inclusion/exclusion that I have just hypothesized initially seems somewhat abstract, and looked at critically may even appear ahistorical and static. It is fair to ask whether the welfare system's communication is not, rather, oriented on historically specific value ideas or value perspectives, such as ideas of "social equality," "social justice," "equality of opportunities," "social security," and so on (see, e.g., Kaufmann, 1977: 511; and for a critical account Leisering, 1997: 258-259). At first glance this kind of theorization, focusing primarily on the dynamics of political and social processes, seems to be a more plausible description of the welfare system's communication. Yet at the same time such specifications, addressing particular points in history, actually block our theoretical view of the communicative logic that structures the particular, historically observable variations in welfare communication. They thus inevitably also block our view of what is general in the historically particular - that is, the continuity within change, as was discussed above for the case of poststructuralist-inspired discourse on "Post-Wohlfahrtsstaatlichkeit." Identifying these value ideas, then, does offer the observer a valuable cross-sectional historical and socio-historical perspective, since the various value ideas identified can usually be found not only in welfare, but also in the historically parallel communicative contexts of politics, economics, the media, and so on. However, for the longitudinal historical perspective, and especially for the specific observation of a part of society (in our case, the welfare system including social work), this approach offers little more than, say, telling us the shade in which a room, itself presumably constant, is painted at a given moment. What room it is, whether or to what extent it really retains the same form, and which colors it permits in principle-all these matters remain unexplained.

It therefore seems more helpful to combine the two perspectives I have sketched - the diachronic and synchronic - as far as possible, within a systems-theoretical approach. ${ }^{8}$ The abstract distinction "societal inclusion/ exclusion" would then not be understood as contradicting per se the assumption that the welfare system's guiding distinctions become manifest in conceptual pairs such as "social justice/social injustice" or "social equality/social

8 I am by no means claiming that systems theory can open up a total view onto the social reality of the welfare system. A systems-theoretical approach to the phenomenon can combine historical longitudinal and cross-sectional perspectives, weaving them into a picture that is meaningful in abstract terms but also capable of empirical specification. However, a perspective of this kind at no point "covers" reality; by its very construction, it necessarily remains a reduction of complexity, and thus a scientific theory. As such, of course, it is right to compete with other scientific objectifications and continue working on itself by drawing in other perspectives, in order to avoid falling prey to naive objectivism. 
inequality." Instead, it is more promising to regard concepts such as "social justice" or "social security" as particular, historically specific value ideas of the welfare system that historically assure the system's connectivity with its societal environment. Value ideas can then be understood as communicative historical "color" that semantically specifies the abstract distinction "societal inclusion/exclusion" and makes it graspable in historical terms-but the guiding distinction that spans the historically divergent value ideas remains the structural question of societal inclusion/exclusion.

\subsection{The Continuing Logic and Function of Communicative Processes in the Welfare System}

Hypothetically naming the German welfare system's guiding distinction does not in itself tell us much about the internal logic of the system's communication. To be sure, identifying a guiding distinction opens up a path to understanding the welfare system's constant occasions for communication: it gives us access to a reflective self-description of the system. But it says nothing precise about the system's internal dynamics. How exactly does the system process the irritations it receives in accordance with its guiding distinction? How exactly does it deal with those stimuli, and what dynamics arise from this for the system itself and for its interaction with the environment?

"Pure creativity" does not look likely to provide an answer to these questions. Once again, it makes sense to study carefully the existing scholarly communication on the phenomenon of the welfare system. Scrutinizing the debate, it is striking that the dynamics of the object itself - that is, the internal context and the effects that the German welfare system exerts upon itself and other parts of society-were long ignored. Instead, attention focused almost exclusively on the causes and conditions of the welfare system's emergence (see Leisering, 2001: 1216). It is only since the late 1970s that the internal dynamics, consequences, and interactions of the welfare system have also attracted wider interest in the social sciences.

The much-cited crisis rhetoric of this discourse is conspicuous (see, among many others, Alber, 1988; Leisering, 2004: 31-34), but at first sight the more general diagnostic value of such judgments seems to be limited. Crises can hardly be considered specific to the welfare system; there is now broad agreement that they are a general feature of the developmental dynamics of modern societies (see Schimank, 2007: 10). ${ }^{9}$ Looking again, however,

9 As more and more different, system-specific logics are simultaneously established and radicalized, modern society can be interpreted in general as a social phenomenon that continually produces and intensifies new conflicts and crises. Systems theory describes these as simultaneous and lasting conflicts between different system logics-conflicts that, taken 
what makes the judgments of crisis respecting the German welfare system actually quite helpful for a deeper understanding of the system's communicative logic are the empirical findings upon which, at least in some cases, they are based. This is because such findings permit conclusions to be drawn on the German welfare system's ineffectiveness in achieving the more or less unanimously articulated norms of "social justice," "social integration," and so on (on the formulation of these norms see, e.g., Thole et al., 2005; for the U.S. see, e.g., Figueira-McDonough, 2007). According to much research, the existing German welfare system produces very little added "social justice" and/or "social integration" (Dollinger, 2008: 36). If anything, some of the system's attempts to exercise influence seem to generate quite contrary effects (see, e.g., Kaufmann et al., 1982: 81; Leisering, 1997: 253; Leisering and Voges, 1997; Leisering and Leibfried, 2001: 144-167; Alber, 2003; Schelkle, 2004: 138; Gredig and Wilhelm, 2007; Mohr, 2007: 64-72; Lessenich, 2008: 10-11; for the U.S. also, e.g., Hasenfeld, 1992: 268-269). This occurs both directly, when problematic consequences arise immediately from interventions, and indirectly: when some individuals are more fully included, the exclusion of the others is aggravated (see Leisering, 2005: 260).

Yet it would be wrong to make or understand this assertion of ineffectiveness or counterproductivity too sweepingly. To reach adequately nuanced judgments on the inclusion or reinclusion effects of the welfare system, clear distinctions must be drawn between individual subgroups of addressees (see, e.g., Leisering, 1997). In fact, in most cases the likelihood of particular populations' societal inclusion or reinclusion appears to depend on their own respective skills and resources (Leisering and Voges, 1997). That implies not an inclusion effect (or at least not a structural one) in terms of social redistribution, but rather that the German welfare system reproduces a "Matthew effect" of accumulated advantage in respect to social life situations (see Tennstedt, 1976: 145). ${ }^{10}$

This statement should not be equated with the assertion that the existing German welfare system is somehow futile in itself. After all, if the German welfare system were futile, presumably it simply would not exist at all. If studies of the German welfare system come to contradictory conclusions re-

together, lead to a continuing state of crisis. At the same time, however, it is precisely this situation that assures the relative stability of modern societies, because the different, conflicting subsystem logics constantly limit each others' expansionism (for more detail see, e.g., Luhmann, 1998: 1087; Willke, 1993: 94; Leisering, 2001: 1218).

10 At this point it becomes clear why the German welfare system is often attributed to the politically conservative, because status-maintaining, regime (see Esping-Andersen, 1990; Seeleib-Kaiser, 2007; for social work, see also Jewell, 2007; for a more differentiated view, see Leitner in this volume). As I will show further on, the systems-theoretical perspective on the German welfare system goes a step further in its analysis. 
garding the success with which "social justice" is produced and addressee groups societally reincluded, that may prompt political deliberations on whether the system is working "wrongly" or ineffectually. In terms of systems theory, however, a more pressing implication is the need to ask critically what the key function of the German welfare system is if it is not the actual production or redistribution of social justice.

The ambivalence of existing theoretical and empirical findings on these objectives suggests that the German welfare system's frequently propagated claim to produce "social justice," "social integration," and so on does not coincide with the sociologically discernible function of the system. It therefore seems misleading to assess the function of the welfare system in terms of the direct accomplishment of the goals customarily named by the system itself (see also Kaufmann, 1977: 497-498; Offe, 1993: 196; Gredig and Wilhelm, 2007: 244-245; Kaufmann, 2012b). At the same time, of course, we cannot ignore the fact that communication within the welfare system takes place with constant reference to precisely those goals. It is by setting the two levels in relation to each other that a key insight can be attained through a systemstheoretical approach to the welfare system. Using this approach, it becomes clear that the function of the German welfare system lies in its use of labels such as "social justice" or "social integration" to communicatively process the problem of societal inclusion/exclusion by constantly highlighting it. In fact, the problem is not solved but, precisely, highlighted, through broader concepts such as "social justice," "social security," or "social integration" and on a more specific level through the semantics of "case," "support measure," or "outcome" (see Fuchs, 2004: 25; more generally also Luhmann, 1973: 179-181). The functional logic of the welfare system is thus not the actual accomplishment of "social integration" or "social justice" through social redistribution, securing social status, etc., but rather the constant talk of these matters in combination with institutionalized measures-measures whose positive impact on inclusion is not, however, structurally demonstrable but only made communicatively connectible with the social environment.

The German welfare system ${ }^{11}$ is not, then, structured such as to generate processes that include or reinclude groups of addressees into other societal subsystems. Although this may occur in individual cases, it is not purposeful or targeted. A specific case could turn out quite differently without essentially affecting the communicative logic of the welfare system. The German welfare system - and this also applies to the specific case of social work-fulfills its function by the mere fact of recognizing and negotiating a particular case

11 Hypothetically, these points could be extrapolated to other national welfare systems, although to my knowledge no detailed studies of this kind yet exist. 
as such, in other words by drawing it into the communicative context of problems of societal exclusion. This alone already constitutes the crucial resolution of the societal problem. One might also say: The function of the German welfare system consists neither in producing or favoring societal inclusion, nor in actively preventing it. Rather, it is found in the communicative concern with societal exclusion using a distinct language by means of which the notion of "total social inclusion" is represented as normatively desirable and realizable.

\section{Conclusion: The Continuous Change of German Welfare}

What conclusions can we draw from the above discussion for the question of the relationship between change and continuity in the German welfare system today?

According to the analysis I have presented, the continuing communicative thematization of societal inclusion/exclusion may be named as a lasting function of the German welfare system. In that process, successive vocabularies of ideal values arise and subside, corresponding historically to the wider development of society. In recent times, the vocabulary of "activation," "workfare," or "social investment" has been conceptually en vogue, but this by no means poses a substantive challenge to the welfare system's guiding distinction. The problem of social or societal inclusion/exclusion, which the system must constantly resolve, is now merely eclectically reinterpreted through the lens of "activation," whereas in the past it was viewed through the lens of "relief" or "protection." That does not fundamentally change the function of the welfare system in relation to society (see also Lamping and Schridde, 2004: 44).

Concomitantly, we may assume that although the role of the state has changed in the welfare system's program, in other words in doctrinal terms, this does not vindicate objectivist assertions of a general destatization of the system and a change in its manner of functioning. Neither does it imply a lesser or greater degree of effectiveness in accomplishing the goals that the system sets out in doctrinal terms. In the era of the "activating state," the German welfare system's claims to produce social justice, social security, prosperity, and integration within society as a whole palpably fail to match its empirically and theoretically observable effects. Yet this does not distinguish the current epoch from previous phases. The incongruence of doctrine and function that we see today is anything but a new phenomenon. Perhaps it is merely more clearly visible in the current phase of doctrinal upheaval than in 
times of a "normal" welfare state, to paraphrase Thomas S. Kuhn (1970): because the German welfare system's adjustment to the new doctrine is still in progress, and the new doctrine is not yet presenting a unified external front, it is easier for social science to identify incongruences and discontinuities - but at the same time it is more difficult to keep sight of the congruences and continuities that accompany the transformation.

The approach I have applied, inspired by systems theory, may provide an instructive complement to the currently prevalent discourse on the transformation of social policy and social work, especially regarding the hypotheses of an increasing orientation on economics and competition (see also Bode, 2004: 79). It has the advantage of keeping visible the ways that the German welfare system continues to function across all its doctrinal transformations. The system - such is my proposed systems-theoretical explanation-does just what it has done throughout its existence: doctrinally it declares exclusionary tendencies to be scandalous, while programmatically it responds to them with its three key forms of control, legislation, money, and professionalism, by constantly processing them in communication. The system does not thereby create solutions for problems of social inclusion and exclusion. It is their solution. And we may predict that it is likely to remain their solution for the time being, well beyond the current phase of doctrinal reencoding.

\section{References}

Achinger H (1958) Sozialpolitik als Gesellschaftspolitik. Von der Arbeiterfrage zum Wohlfahrtsstaat. Reinbek bei Hamburg: Rowohlt Verlag.

Alber J (1988) Is There a Crisis of the Welfare State? Crossnational Evidence from Europe, North America, and Japan. European Sociological Revue 4 (3): 181-203.

Alber J (2003) Recent Developments in the German Welfare State: Basic Continuity or Paradigm Shift? In: Neil G and Van Voorhis R (eds) Changing Patterns of Social Protection. London: Transaction Publishers, 9-74.

Blank RM (2004) Is the Market Moral? A Dialogue on Religion, Economics, and Justice. Washington, DC: Brookings Institution.

Bode I (2004) Das Ende der Einheit - die Transformation von Staatlichkeit im disorganisierten Wohlfahrtskapitalismus. In: Lütz S and Czada R (eds) WohlfahrtsstaatTransformation und Perspektiven. Wiesbaden: VS, 67-89.

Bode I (2006) Disorganized Welfare Mixes: Voluntary Agencies and New Governance Regimes in Western Europe. Journal of European Social Policy 16: 346-359.

Bommes M and Koch U (2004) Die Organisation von Hilfe — kein politisches Programm zur Gleichstellung. In: Merten R and Scherr A (eds) Inklusion und Exklusion in der Sozialen Arbeit. Wiesbaden: VS, 75-96.

Brodkin EZ (2009) Human Service Organizations as Political Institutions. In Hasenfeld Y (ed) Human Services as Complex Organizations. Second Edition. New York: Sage. 
Bütow B, Chassé KA and Hirt R (eds) (2008) Soziale Arbeit nach dem sozialpädagogischen Jahrhundert. Entwicklungen im Post-Wohlfahrtsstaat. Opladen and Farmington Hills: Barbara Budrich.

Bundesministerium für Arbeit und Soziales (2008) Sozialbudget 2007. Berlin: www.sozialpolitik-aktuell.de/index.php/finanzierung-datensammlung.html\#iiisozialleistungensozialbudget (Download: 01-25-2010).

Clarke J (2004) Changing Welfare, Changing States: New Directions in Social Policy. London: Sage.

Clarke J (2009) Governing the Social? The Problem of Thinking Beyond Welfare States. Paper for the University of Chicago School of Social Service Administration's Centennial Conference: "Welfare State Transformation since 1970: Comparative International Perspectives" in Paris. April 24-25, 2009. Unpublished presentation.

Dollinger B (2008) Sozialpädagogische Theorie zwischen Analyse und Zeitdiagnose. In: Widersprüche. Zeitschrift für sozialistische Politik im Bildungs-, Gesundheits- und Sozialbereich. H. 108: 31-42.

Esping-Andersen G (1990) The Three Worlds of Welfare Capitalism, Cambridge: Cambridge University Press.

Figueira-McDonough J (2007) The Welfare State and Social Work. Pursuing Social Justice. Thousand Oaks et al.: Sage.

Fuchs P (2004) Die Moral des Systems Sozialer Arbeit-systematisch. In: Merten R and Scherr A (eds) Inklusion und Exklusion in der Sozialen Arbeit. Wiesbaden: VS, 17-32.

Gewirtz S (2002) The Managerial School. Post-welfarism and Social Justice in Education. London and New York: Routledge.

Gredig D and Wilhelm E (2007) Erzeugung und Verfestigung von gesellschaftlicher Ungleichheit durch Sozialpolitik und Soziale Arbeit. In: Brumlik M and Merkens H (eds) Bildung. Macht. Gesellschaft. Beiträge zum 20. Kongress der Deutschen Gesellschaft für Erziehungswissenschaft. Opladen: Barbara Budrich, 243-258.

Hancock M D and Sjoberg G (eds) (1972) Politics in the Post-Welfare State: Responses to the New Individualism. New York and London: Columbia University.

Hasenfeld Y (1992) Power in Social Work Practice. In: Hasenfeld Y (ed) Human Services as Complex Organizations. Newbury Park et al.: Sage, 259-275.

Hegelich S and Meyer H (2009) Conflict, Negotiation, Social Peace: The German Welfare System. In: Schubert K, Hegelich S, and Bazant U (eds) The Handbook of European Welfare Systems. New York: Routledge, 127-148.

Heite C (2010) Soziale Arbeit—Post-Wohlfahrtsstaat—Geschlecht. Zum Zusammenhang von Professionalität und Politik. In: Böllert K and Oelkers N (eds) Frauenpolitik in Familienhand? Neue Verhältnisse in Konkurrenz, Autonomie oder Kooperation. Wiesbaden: VS, 25-38.

Jewell CJ (2007) Agents of the Welfare State. How Caseworkers Respond to Need in the United States, Germany, and Sweden. New York: Palgrave Macmillan.

Katz MB (1996) In the Shadow of the Poorhouse. A Social History of Welfare in America. Tenth Anniversary Edition. Revised and Updated. New York: Basic Books.

Kaufmann F-X (1977) Zur Problematik der Effektivität und ihrer Erfassung im Bereich der sozialen Sicherung. In: Külp B and Haas H-D (eds.) Soziale Probleme der modernen Industriegesellschaft. Band 2. Berlin: Duncker \& Humblot, 489-517.

Kaufmann F-X (2012a) Thinking About Social Policy: The German Tradition. Heidelberg: Springer.

Kaufmann F-X (2012b) Variations of the Welfare State: Great Britain, Sweden, France and Germany Between Capitalism and Socialism. Heidelberg: Springer. 
Kaufmann F-X et al. (1982) Verteilungswirkungen sozialer Dienste. Das Beispiel Kindergarten. Frankfurt am Main and New York: Campus.

Kemmerling A and Bruttel O (2006) "New Politics" in German Labour Market Policy? The Implications of the recent Hartz Reforms for the German Welfare State. West European Politics 29: 90-112.

Kessl F (2006) "Activating Youth Welfare"-an Example for the Neo-social Rearrangement of German Social Policy. In: Marston G and McDonald C (eds) Analysing Social Policy. A Governmental Approach. Aldershot: Edward Elgar, 145-164.

Kessl F (2009) Critical Reflexivity, Social Work, and the Emerging European Post-welfare States. European Journal of Social Work 12: 305-317.

Kessl F and Otto H-U (eds) (2008a) Soziale Arbeit ohne Wohlfahrtsstaat? Zeitdiagnosen, Problematisierungen und Perspektiven. Weinheim and Munich: Juventa.

Kessl F and Otto H-U (2008b) Soziale Arbeit ohne Wohlfahrtsstaat? In: Kessl F and Otto H-U (eds) Soziale Arbeit ohne Wohlfahrtsstaat? Zeitdiagnosen, Problematisierungen und Perspektiven. Weinheim and Munich: Juventa, 7-21.

Kuchler B (2006) Bourdieu und Luhmann über den Wohlfahrtsstaat. Die Autonomie gesellschaftlicher Teilbereiche und die Asymmetrie der Gesellschaftstheorie. Zeitschrift für Soziologie 35: 5-23.

Kuhn TS (1970) The Structure of Scientific Revolutions. Chicago: University of Chicago Press.

Lampert H and Althammer JW (2007) Lehrbuch der Sozialpolitik. 8. Auflage. Berlin et al.: Springer.

Lamping W and Schridde H (2004) Der „Aktivierende Sozialstaat“—ordnungs- und steuerungstheoretische Aspekte. In: Lütz $\mathrm{S}$ and Czada R (eds) WohlfahrtsstaatTransformation und Perspektiven. Wiesbaden: VS, 39-65.

Leisering L (1997) „Soziale Ausgrenzung“. Zur handlungstheoretischen Fundierung eines aktuellen sozialpolitischen Diskurses. In: Hradil S (ed) Differenz und Integration. Die Zukunft moderner Gesellschaften. Verhandlungen des 28. Kongresses der Deutschen Gesellschaft für Soziologie in Dresden 1996. Frankfurt am Main and New York: Campus, 1039-1053.

Leisering L (2001) Ambivalenz und Immanenz. Die soziologische Kritik am Wohlfahrtsstaat. In: Allmendinger J (ed.) Gute Gesellschaft? Verhandlungen des 30. Kongresses der Deutschen Gesellschaft für Soziologie in Köln 2000. Opladen: Leske + Budrich, 1210-1237.

Leisering L (2004) Der deutsche Sozialstaat. Entfaltung und Krise eines Sozialmodells. In: Frech S and Schmid J (eds) Der Sozialstaat. Reform, Umbau, Abbau? Schwalbach am Taunus: Wochenschau, 10-42.

Leisering L (2005) The Welfare State in Post-War Germany. In: Vivekanandan B and Kurian N (eds) Welfare States and the Future. Basingstoke: Palgrave Macmillan, 113130.

Leisering L and Leibfried S (2001) Time and Poverty in Western Welfare States: United Germany in perspective. Cambridge: Cambridge University Press.

Leisering L and Voges W (1997) Secondary Poverty in the Welfare State. Do Social Security Institutions Create Their Own Clients? An Application of Longitudinal Analysis. In: Keilman $\mathrm{N}$ et al. (eds) Poverty and Economic Inequality in Industrialized Western Countries. Oslo: Scandinavian University, 205-232.

Lessenich S (2000) Soziologische Erklärungsansätze zu Entstehung und Funktion des Sozialstaats. In: Allmendinger J and Ludwig-Mayerhofer W (eds) Soziologie des Sozial- 
staats. Gesellschaftliche Grundlagen, historische Zusammenhänge und aktuelle Entwicklungstendenzen. Weinheim and Munich: Juventa, 39-78.

Lessenich S (2008) Die Neuerfindung des Sozialen. Der Sozialstaat im flexiblen Kapitalismus. Bielefeld: Transcript.

Lessenich S (2011) Mobilization and Control in the "Active Society". In: Bröckling U, Krasmann S and Lemke T (eds) Governmentality. Current Issues and Future Challenges. New York and London: Routledge, 304-319.

Lipsky M (1980) Street-Level Bureaucracy. Dilemmas of the Individual in Public Services. New York: Russell Sage Foundation.

Luhmann N (1973) Zweckbegriff und Systemrationalität. Über die Funktion von Zwecken in sozialen Systemen. 2. Auflage. Frankfurt am Main: Suhrkamp.

Luhmann N (1986) Die Lebenswelt - nach Rücksprache mit Phänomenologen. In: Archiv für Rechts- und Sozialphilosophie 72: 176-194.

Luhmann N (1990) Political Theory in the Welfare State. Berlin: de Gruyter.

Luhmann N (1998) Die Gesellschaft der Gesellschaft. 2 Bände. Frankfurt am Main: Suhrkamp.

Lutz T (2010) Soziale Arbeit im Kontrolldiskurs. Jugendhilfe und ihre Akteure in postwohlfahrtstaatlichen Gesellschaften. Wiesbaden: VS.

Lutz T and Ziegler H (2005) Soziale Arbeit im Post-Wohlfahrtsstaat. Bewahrer oder Totengräber des Rehabilitationsideals? In: Widersprüche. Zeitschrift für sozialistische Politik im Bildungs-, Gesundheits- und Sozialbereich. H. 97: 123-134.

Mohr K (2007) Soziale Exklusion im Wohlfahrtsstaat. Arbeitslosensicherung und Sozialhilfe in Großbritannien und Deutschland. Wiesbaden: VS.

Neumann S and Sandermann P (2007) Uneinheitlich einheitlich. Über die Sozialpädagogik der sozialpädagogischen Theorie. In: Schweizerische Zeitschrift für Soziale Arbeit 3: 929.

Oelkers N (2008) Die Umverteilung von Verantwortung zwischen Staat und Eltern. Konturen post-wohlfahrtsstaatlicher Transformation eines sozialpädagogischen Feldes. In: Kessl F and Otto H-U (eds) Soziale Arbeit ohne Wohlfahrtsstaat? Zeitdiagnosen, Problematisierungen und Perspektiven. Weinheim und Munich: Juventa, 71-86.

Oelkers N and Richter M (2010) Die post-wohlfahrtsstaatliche Neuordnung des Familialen. In: Böllert K and Oelkers N (eds) Frauenpolitik in Familienhand? Neue Verhältnisse in Konkurrenz, Autonomie oder Kooperation. Wiesbaden: VS, 15-23.

Offe C (1993) Contradictions of the Welfare State. New York: MIT.

Olk T (2011): Freie Träger in der Sozialen Arbeit. In: Otto H-U and Thiersch H (eds) Handbuch der Sozialarbeit/Sozialpädagogik. 4., völlig neu bearbeitete Auflage. Munich and Basel: Ernst Reinhardt, 415-428.

Pottage A (1998) Power As an Art of Contingency: Luhmann, Deleuze, Foucault. In: Economy and Society 27: 1-27.

Sandermann P (2009) Die neue Diskussion um Gemeinschaft. Ein Erklärungsansatz mit Blick auf die Reform des Wohlfahrtssystems. Bielefeld: Transcript.

Sandermann P (2010) Die Kontinuität im Wandlungsprozess des bundesrepublikanischen Wohlfahrtssystems. In: Neue Praxis 40: 447-464.

Sandermann P et al. (2011) Die Praxis der Citizen-Effektivierung. Oder: Wie ernst nimmt die Forschung zur Sozialen Arbeit ihren Gesellschaftsbezug? In: Kommission Sozialpädagogik (ed): Bildung des Effective Citizen-Sozialpädagogik auf dem Weg zu einem neuen Sozialentwurf. Weinheim and Munich: Juventa Verlag, 35-51.

Sandermann P, Urban U and Schruth P (2007) Unter Druck und Zwang. Zur staatlichen Existenzgefährdung junger Volljähriger. In: Sozial Extra 7-8/2007: 12-17. 
Schelkle W (2004) Kritik der Wohlfahrtsstaatskritik. WestEnd. Neue Zeitschrift für Sozialforschung 3: 133-141.

Scherr A (2004) Exklusionsindividualität, Lebensführung und Soziale Arbeit. In: Merten R and Scherr A (eds) Inklusion und Exklusion in der Sozialen Arbeit. Wiesbaden: VS, 55-74.

Schimank U (2007) Theorien gesellschaftlicher Differenzierung. 3. Auflage. Wiesbaden: VS.

Schmid J (2010) Wohlfahrtsstaaten im Vergleich. Soziale Sicherung in Europa: Organisation, Finanzierung, Leistungen und Probleme. 3., aktualisierte und erweiterte Auflage. Wiesbaden: VS.

Seeleib-Kaiser M (2007) From Conservative to Liberal-Communitarian Welfare. Can the reformed German Welfare State survive? Barnett Papers in Social Research 4: 1-37.

Stichweh R (2000) Systems Theory as an Alternative to Action Theory? The Rise of 'Communication' as a Theoretical Option. Acta Sociologica 43: 5-13.

Stichweh R (2005) Inklusion und Exklusion. Studien zur Gesellschaftstheorie. Bielefeld: Transcript.

Tennstedt F (1976) Zur Ökonomisierung und Verrechtlichung in der Sozialpolitik. In: Murswieck A (ed) Staatliche Politik im Sozialsektor. Munich: Piper, 139-165.

Thole W et al. (eds) (2005) Soziale Arbeit im öffentlichen Raum. Soziale Gerechtigkeit in der Gestaltung des Sozialen. Wiesbaden: VS.

Willke H (1989a) Disenchantment of the State: Outline of a Systems Theoretical Argumentation. In: Ellwein T et al. (eds) Yearbook on Government and Public Administration 1987/88. Baden-Baden: Nomos, 225-246.

Willke H (1989b) Zum Problem staatlicher Steuerung im Bereich der Sozialpolitik. In: Vobruba G (ed) Der wirtschaftliche Wert der Sozialpolitik. Berlin: Duncker \& Humblot, 109-120.

Willke H (1993) Systemtheorie entwickelter Gesellschaften. Dynamik und Riskanz moderner gesellschaftlicher Selbstorganisation. Weinheim and Munich: Juventa.

Ziegler H (2008) Sozialpädagogik nach dem Neo-Liberalismus: Skizzen einer postsozialstaatlichen Formierung Sozialer Arbeit. In: Bütow B, Chassé KA and Hirt R (eds) Soziale Arbeit nach dem sozialpädagogischen Jahrhundert. Entwicklungen im Post-Wohlfahrtsstaat. Opladen and Farmington Hills: Barbara Budrich, 159-176.

Züchner I (2007) Aufstieg im Schatten des Wohlfahrtsstaates. Expansion und aktuelle Lage der Sozialen Arbeit im internationalen Vergleich. Weinheim and Munich: Juventa. 



\section{Vincent Dubois}

\section{The Functions of Bureaucratic Routines in a Changing Welfare State: On Interactions with Recipients in French Welfare Offices}

The relationships between clients and agents at the front desks of government agencies, particularly welfare agencies, have received unprecedented attention in France since the 1990s. A number of reasons explain this surge of interest in a dimension of public policy hitherto generally neglected both by institutional actors and observers alike. First, so-called public service modernization programs and then state reform programs have included the objective of improving relationships between the administrations and their "usagers" [users], now referred to as clients (see Warin, 1997). Welfare agencies were quickly and intensely enlisted in this general reform undertaking. Combining a management-oriented approach and the specialization of services provided to disadvantaged persons (see Siblot, 2006), these programs have contributed to the practical and symbolic production of the problem of "handling the excluded," even beyond the level of welfare organizations, especially when public service agents deal with those referred to as "des publics difficiles" [difficult publics] in the institutional lingo: "jeunes des cites" [inner-city kids] in public transport, "SDF" [homeless people] in hospitals, and "les exclus" [the excluded] in general. Lastly, such a framing of social issues resonated with the development of studies focusing on individuals or microrelationships in social sciences (see Weller, 1998). As a result, scholars were eager to take interpersonal exchanges in public administrations and welfare as an object of study or as a level of observation. Yet, I argue that there are deeper and less contextual reasons to focus on inter-individual relationships in welfare administrations, mainly exemplified here by front desk interactions.

Building on Simmel's approach, I posit that the objective condition of economic deprivation is not a sufficient criterion to define the poor as a social group (see Simmel, 1965); it is rather the acknowledgement of a collective duty to provide them support that defines the poor as such. In this perspective, the social existence of the poor relies on the "assistance relationship." While deciding whom society has to help, this relationship institutes 
the poor as a group and designates the individuals who are part of it. Front desk relationships in welfare organizations are the practical realizations of the assistance relationship: those asking for help meet those invested with the authority to provide it. Therefore, studying these encounters does not only amount to describing how social service provision works; it also means observing the concrete process of the institution of the poor, in the dynamic sense of the term.

Front desk interactions and more broadly direct exchanges between administrative agents and recipients reveal the type of relationship that develops between welfare provision and those entitled to benefiting from it. They are quite as mutable as the social definitions of poverty they are associated with. By studying their transformations, we can evidence new ways of defining the poor (the "entitled") at work in the concrete functioning of the welfare state. In this chapter, I set about to do this focusing on contemporary France. I rely on a study conducted in family benefit offices, which, in addition to the usual family and housing benefits, also attribute minimum benefits (see Dubois, 2010) and on an investigation of the practices used to control minimum benefit recipients. I show that the importance taken on by these face-to-face administrative interactions owes much to the redefinition of this relationship in an unprecedented context of progressive decline of social rights and worsening socio-economic problems. Then, I show that far from being merely a neutral routine of a social policy implementation, the methods used in this relational and bureaucratic work constitute its very core. Ultimately, I assess the impact of these new relationships and methods on welfare recipients.

\section{Declining Social Rights and Increasing Need for Assistance}

The meaning and the importance of face-to-face relationships between welfare claimants and the representatives of institutions in charge of welfare provision vary depending on the features of the welfare benefits and on the socioeconomic situation, and therefore according to the periods and national configurations under consideration. I posit that these relationships have become increasingly important in France, particularly since the late 1980s, and that they are less and less mere bureaucratic routines. Instead they have become more strategic interactions - in the strong sense of the term. This evolution derives both from transformations in the status of welfare applicants and in social policy, and from the effects of persisting mass unemployment, which keeps much of the population dependent towards welfare organizations. 


\section{Recipients or Entitled?}

In order to illustrate the impact of different types of social policy on administrative relationships between applicants and agents, I suggest starting from a rough ideal-typical distinction. In a welfare system where acquiring a specific status gives access to benefits (particularly when contributions have been paid), the relationship to welfare administrations pertaining to welfare provision can be limited to a formal and mostly technical exchange, in the sense that the way the interaction goes has no effect on the actual payment of benefits. In such a setting, the street-level bureaucrat's work consists in checking the presence of the documents required for processing the file, and if need be give additional information on the calculation of benefits or the schedule of payouts. The recipient is mostly asked to provide the required certificates and attestations, and occasionally to give additional explanations in the most complex situations. The face-to-face relationships can therefore be reduced to a limited number of brief interactions (sometimes only one), and seen merely in terms of effectiveness in the processing of files.

In other systems, exemplified among others by the U.S. case, which tend towards a model of public charity (see Castel, 1978) or "regulation of the poor" (see Piven and Cloward, 1993), the situation is entirely different. In the absence of well-defined social rights, replaced by allowances and assistance in kind handed out on a case-by-case basis, confrontation to the institutions becomes a complex and crucial matter. The welfare agent assesses the applicant's situation and decides which features to take into account in the process of ruling on each case. The "client," on the other hand, must present his situation and his person in a way that gives credit to his request for assistance. Such interactions are structured by a key requirement: establishing the truthfulness of the claimant's presentation to come up with a decision on the need for assistance, the form it will take and the amount of money provided (if any). As Frederic Wiseman's illuminating documentary on a New York City welfare office ("Welfare") shows, the administrative relationship is then far from a mere formality; it becomes a tense, complex and literally decisive situation, since it is on this occasion that welfare provision is granted or refused.

These interactions have also become decisive, albeit for partly different reasons, after the welfare reform that puts strong emphasis on returning to work (see Morgen, Acker and Weigt, 2010). Face-to-face encounters are no longer only about granting a benefit; they are conceived as incentives to work. Agents paradoxically strive to "enforce "self-sufficiency"" (above reference: see especially p. 323 and 325-27), by teaching welfare recipients the value of work or having recourse to more directly coercive practices (see 
above reference: 64-83). Recipients must show that they "deserve" public support, not only because they are poor, but because they are showing efforts to fight their poverty. The legacy of the paternalistic tradition of public charity combined with the rise of workfare leads to a form of "disciplinarization" of the poor, displayed in their encounters with welfare agents (see Soss et al., 2011).

Describing recent transformations in French social policies as a return to the public charity model or an application of the workfare model (which is composite anyway) would be an exaggeration. They have, however, been getting closer to this ideal-type; a number of recent trends in the public treatment of poverty in France have impacted the recipients' relationships to welfare organizations. The emergency fund implemented in 1998 following a mobilization by the unemployed constituted a typical manifestation of the new obligation required from the poor, who no longer have to fulfill a range of criteria, but must be able to showcase their poverty (see Fassin, 2012). This exceptional program required the unemployed to send a claim consisting in a letter explaining their situation and all information they would find relevant in order to convince ad hoc local committees that they deserved this occasional help. Conversely to a classical social welfare program defining $a$ priori general rules to be applied to individual cases, this emergency aid was decided after the a posteriori evaluation of rationales conceived on an individual basis by the claimants themselves. More broadly speaking, the implementation of the so-called "new social policies," including an increasingly important minimum benefit in 1998, the "Revenu Minimum d'Insertion" (RMI), has resulted in a more case-based approach, with individual accounts being produced for and assessed by institutional representatives (see Astier, 1996). Increasingly, fact-based criteria (subject to appreciation) prevail over law-based criteria (relating to a status), which makes the process of assessing individual situations in legal terms more difficult (see Choquet and Sayn, 2000). For instance, the very vague criterion of "isolement" [isolation] considered in the provision of the "Allocation de Parent Isolé, API" [single parent benefit] and of the minimum benefit [RMI] is interpreted in very diverse ways. The evaluation of individual cases is now a complement, if not a replacement, to the attribution of social rights. In this increasingly workfareoriented system, behaviors are assessed to establish whether individuals really want to return to work or not. This transpired first in the field of employment: in 2001, the implementation of the "Plan d'Aide au Retour à l'Emploi PARE" [return to work assistance plan] reinforced the obligation for the unemployed to bring evidence of an "active job search" during regular interviews. Numerous reforms have since resulted in the increase in the number 
and importance of institutional interactions: interviews are more frequent and may lead to the suspension or cancellation of unemployment benefit payouts and more and more checks are conducted to ensure that recipients are genuinely looking for work. In the field of so-called solidarity policies, reforms have been pushing for "activation." The "Revenu de Solidarité Active, RSA" [active solidarity benefit], more work-oriented and whose provision is subject to regular individual follow-up interviews, has for instance replaced the RMI and API in 2009.

In a context of persisting mass unemployment, the individual responsibility of the "able-bodied poor" is increasingly singled out, and assistance relationships tend to be structured around the suspicion of institutional agents towards the applicants' justifications. Since both the conviction that every salary deserves work (see Murard, 2002) and the idea that this work or the hindrances to doing this work might not in fact exist have come to prevail, the relationships between institutions and welfare claimants have become increasingly decisive and conflict-laden. The claimant must declare, explain, prove, justify and convince, as opposed to the agent who must understand, control, assess and rule. Checks and individual rulings have always been carried out by social workers, who generally have dispositions (a "vocation") and a professional socialization that allow them to master these practices. They are now also administrative employees who control and rule on individual cases, but with no "tools" at their disposal and generally less critical distance. All of this illustrates the general thesis of the "policy-making role of street-level bureaucrats" (Lipsky, 1980: 13-25) and more precisely, shows how social and historical conditions are crucial to the importance of that role. In the case under study, I have not observed the decline of their discretionary power (see Evans and Harris, 2004). Rather, I argue that this discretionary power has been extended to the lower levels of welfare administrations. Discretion is no longer the privilege of trained and professional social workers and is now also being exerted by bureaucratic clerks who master the administrative procedures but who have had no training in social work.

\section{A Growing Demand}

The new importance and meaning of administrative relationships cannot only be attributed to transformations in social policy. It also relates to socioeconomic conditions that affect the volume and the structure of demand. Self-evidently, the degradation of the economic situation in the poorest households and continuing high unemployment rates have resulted in a steady increase in welfare applications and recourse to charity. Every year, the media reports the increase in the number of meals served by the "Restau- 
rants du Coeur" charity; though they make for less good TV, the statistics on visits to the front desk of welfare organizations are no less edifying. Admittedly, the number of visits is only a very rough indicator of the evolutions in front desk relationships. However, insofar as the reasons for visiting-fearing payouts might not arrive, looking for additional benefits when suffering from great financial difficulties, not knowing how the administrative machinery works or needing to talk about one's problems - orient the attitudes and practices of the claimants (deference, prospection, aggressiveness, self-surrendering or display of misfortune), this indicator at least reveals possible trends. The number of visits has increased from slightly below 15 million in 1995 to more than 18 million in 2008 and nearly 21 million in 2009: the increase observed was higher during the first year of the financial crisis than over the entire preceding decade. This is a far greater increase than that of the number of recipients, which has gone from 9.5 million in 1995 to slightly above 11 million in 2009: it can therefore be explained by a greater frequency of the visits. While this is not the only explanation, the global socio-economic situation in terms of poverty and employment therefore has a direct impact on the relationships with relevant administrations, including as far as physical reception is concerned.

The evolution is not only quantitative; it derives from the expression of a more complex and varied demand. The instability and the complexity of individual situations, which grow as the boundaries between work and unemployment become increasingly unclear and as family structures change, lead applicants to expose problems that call for active involvement from the agents, particularly since, as part of the aforementioned evolutions in social policy, the adaptation of the institutional response to the diversity of the situations has become a requirement where the standardized enforcement of general rules used to prevail.

Furthermore, the relationship with a welfare institution, even in such an impersonal and bureaucratic setting as front desk reception, does not only amount to attempts to solve objective problems through the provision of a regular or occasional benefit. Despite the inconvenience of dealing with an administration in terms of waiting times and bureaucracy, which are perceived in variable ways depending on the visitor's objective position and "moral career" (Goffman, 1961: 117-158), as well as the potential effects of domination that can derive from the scornful attitude of a reception agent or an institutional sanction, welfare claimants still may expect secondary benefits from the administrative relationship. The front desks of welfare organizations are subject to a number of lateral uses which, as they develop, contribute to reinforcing and diversifying the social function of the relationships that 
take place there: being reassured about the processing of a request, finding someone with whom to share one's troubles, sometimes getting advice when lost in life or taking steps to maintain the identity of individuals who are liable to pick themselves up and get out of poverty...

\section{The "Relational" as a Way to Handle Social Issues}

The increasing importance of face-to-face relationships is not simply, as we have seen, an organizational epiphenomenon of the transformations of social issues. Quite the opposite in fact: it is part and parcel of the handling of social problems, since the practical redefinition of the institutional treatment of the precarious fractions of the working-class has given way to a new form of management.

\section{A New Social Administration}

As they move away from an impersonal model characterized by the routine application of standardized rules, front desk relationships in welfare organizations have arguably become less "bureaucratic." Meanwhile, the growing complexity of the procedures and situations often leads social workers to devote more and more of their time to file processing and committee meetings to the detriment of direct interaction with the population. The "relational" still constitutes the central feature of social workers' professional identity (Dubet, 2002: 231); whether it is still their main activity is less certain, however. At any rate, the "relational demands" of unprivileged populations are now less than ever met by social workers, who are overwhelmed and held up by multiple tasks. As a result, part of the relational work with the clients that used to be carried out by social professionals, whose "job and vocation" were initially based on helping the poor, is now being taken over by administrative professionals (such as reception agents), who are supposed to be competent as far as enforcing standards and procedures go, but who have not been trained or prepared to handle poverty. In other words, the "socialization" of the administrative relationship is also the counterpart of a "bureaucratization" of social work.

These two concurrent trends have a combined effect resulting in a watered-down treatment of poor populations, which goes beyond the internal functioning of welfare-oriented organizations. The "excess in social demand" triggered by the increase and diversification of requests for assistance andat least partly and temporarily - encouraged by calls for general mobilization in the "fight against exclusion," has led front desk agents in all kinds of pub- 
lic services to become involved in the follow-up of individuals in difficult situations (Jeannot, 1996), as the case of post offices in working-class neighborhoods shows (Siblot, 2003).

Instead of promoting a specific competence in the handling of social problems, the relational skills of street-level public servants have been valued. Reception trainings generally grant much importance to communicational skills ("being able to listen and make yourself understood"), alternatively borrowing from techniques used in commercial interaction trainings (from smiling to neuro-linguistic programming) and from a psychologytinged register that matches the overall trend towards the individualization of social problems. The strictly social dimension of the relationship is all too often reduced to one session on the "diversity of the publics" or to a roleplaying game aimed at "dealing with situations of conflict."

\section{New Forms of Management of the Poor}

All of this contributes to encouraging a diffraction of the social question. Front desk agents do not address the "global situation" of the applicants, but specific issues regarding them, conceived and delineated as a result of the segmentation of benefits and institutions: housing, health, children, etc. Collectives are not mentioned; "collections of individuals" receive a distinct treatment, broken up into waiting lines and numbers. This reveals an unlikely affinity between recent trends towards the individualization of welfare and the fragmentation that occurs in practice at front desks, often considered as the symbol of bureaucratic archaism. These front desk relationships and the new assistance relationships they witness contribute to replacing the production of the poor as a group by the identification of individuals with distinctive issues, expressed in terms of personal suffering immediately translated into institutional language.

This individualization comes with contrasting trends in the determination of the distance between the protagonists in the relationship. In welfare administration and politics alike, "proximity" is in fashion. This can physically entail the opening of offices in the neighborhoods where poor people live. At another level, this can mean the development of "personalized" relationships that make it possible for reception agents and welfare recipients to know each other, which both facilitates administrative formalities and induces new forms of dependence (Dubois, 2010). Furthermore, this personalization takes on a paradoxical form, as it partly consists in the implementation of a technique linked to the specialization of so-called "relational" professions.

When measuring distance and proximity on the basis of the agents' respective social positions, a growing social gap can be observed. The people 
who come to the front desks have an increasingly low social level since the arrival of the "new publics" (as they are called in the institutional lingo) starting in the late 1980s (RMI recipients who until then did not frequent social security organizations, later refugees and immigrants from Central or Eastern European countries, for instance). Concurrently, the educational and/or social level of the public service employees (including those in direct contact with the population) has become higher, as such functions have become fallback solutions in high unemployment periods for agents that would have held higher positions in better times.

The effects of this growing social gap are not univocal. There can be reactions of rejection and practices of stigmatization of the poor, but there are also cases of unplanned commitment to the socio-relational dimensions of an administrative job chosen by default. In such cases, this commitment does not derive from established professional skills in social matters, but on the agents' personal predispositions: their social "sensibility," the categories of perception of the issues and of the populations they have forged during their trajectory. The forms and limitations of this commitment are determined by professional relationships between co-workers and with the hierarchy, often more prone to spreading stereotypes about the "entitled" poor and to imposing a management and productivity-oriented rationale than to committing to the defense of the underprivileged.

Due to the practical rationales of these "bottom-up social policies," welfare recipients have to contend with greater requirements under the influence of governmental bodies and of the media. "Responsibilization," a word used to call for more autonomy and to express the idea that the poor are responsible for whatever problems they are dealing with is both an official catchphrase and the practical horizon of these face-to-face encounters.

Consequently, instead of merely contrasting the "social magistrature," based on case-by-case appreciation, with a "front desk logic" supposedly amounting to the routine application of pre-established general standards, I argue that it is necessary to comprehend the origins, the rationales and the stakes of the exercise of this power to rule on individual situations, to assign statuses or promote behaviors in bureaucratic relationships.

\section{References}

Astier I (1996) Le Revenu minimum et l'insertion. Paris: Desclée de Brouwer.

Castel R (1978) La "guerre à la pauvreté" aux États-Unis: le statut de la misère dans une société d'abondance. Actes de la recherche en sciences sociales 19: 47-60.

Choquet L-H and Sayn I (2000) Droit de la sécurité sociale et réalité de l'organisation:

l'exemple de la branche famille. Droit et société 44-45: 111-125.

Dubet F (2002) Le déclin de l'institution. Paris: Seuil. 
Dubois V (2010) The Bureaucrat and the Poor: Encounters in French Welfare Offices. Aldershot: Ashgate.

Evans T and Harris J (2004) Street Level Bureaucracy, Social Work and the (Exaggerated) Death of Discretion. British Journal of Social Work 34 (6): 871-895.

Fassin D (2012) Humanitarian Reason. A Moral History of the Present. Berkeley: University of California Press.

Goffman E (1961) Asylums. Essays on the Social Situation of Mental Patients and Other Inmates. Doubleday: Anchor Books.

Jeannot G (1996) When Non-social Public Services Take Care. In: Schulze HJ and Wirth W (eds) Who Cares? Social Service Organizations and their Users. London, New York: Cassel, 63-75.

Lipsky M (1980) Street-level Bureaucracy. New York: Russell Sage Foundation.

Morgen S, Acker J and Weigt J (2010) Stretched Thin. Families, Welfare Work and Welfare Reform. Ithaca: Cornell University Press.

Murard N (2002) Mating Welfare and Workfare: Scenes of a Public Policy in a French Province. Ethnography 3 (3): 299-315.

Piven FF and Cloward R (1993) Regulating the Poor: The Public Functions of Welfare. Updated Edition. New York: Vintage Books.

Siblot Y (2006) Faire valoir ses droits au quotidien. Les services publics dans les quartiers populaires. Paris: Presses de Sciences Po.

Simmel G (1965) The Poor. Social Problems 13 (2): 118-140.

Soss J, Fording RC and Schram SF (2011) Disciplining the Poor: Neoliberal Paternalism and the Persistent Power of Race. Chicago: University of Chicago Press.

Warin P (1997) Quelle modernisation des services publics? Les usagers au cour des réformes. Paris: La Découverte.

Weller JM (1998) La modernisation des services publics par l'usager : une revue de la littérature (1986-1996). Sociologie du Travail 3: 365-392. 


\section{Contributors}

John Clarke, is a Professor of Social Policy at the Open University, Milton Keynes (UK). His fields of interest include cultural studies, welfare state research, and the management of public services.

Vincent Dubois, $\mathrm{PhD}$, is a Professor at the University of Strasbourg, Institute for political studies, Strasbourg (FRA). His fields of interest include welfare fraud policies, language and cultural policies, and, more generally, sociological approaches to public policy.

Robert P. Fairbanks II, PhD, is a Lecturer and Fellow in Urban Studies at the University of Pennsylvania, and a Visiting Assistant Professor of Sociology at Bryn Mawr College, Philadelphia (PA/USA). His fields of interest include urban ethnography, welfare state theory, and critical social policy analysis.

Sigrid Leitner, Dr. phil. habil., is a Professor of Political Sciences and Social Policy at the Cologne University of Applied Sciences, Cologne (GER). Her fields of interest include comparative social policy, gendered effects of social policy, family policy and local social policy.

Richard Münchmeier, Dr. rer. soc. habil., is a Professor Emeritus of Social Pedagogy at the Free University of Berlin, Department of Education and Psychology, Berlin (GER). His fields of interest include child welfare research, history of social work and social policy, and youth studies.

Jamie Peck, PhD, holds the Canada Research Chair in Urban \& Regional Political Economy and is a Professor of Geography at the University of British Columbia, Vancouver (BC/CAN). His fields of interest include state restructuring, theories of economic governance and regulation, and geographical political economy.

Philipp Sandermann, Dr. phil., is a Professor of Social Pedagogy at the University of Trier, Department I (Pedagogy), Trier (GER). His fields of interest 
include welfare systems theory, comparative social work research, and child advocacy/welfare consumer protection.

Nik Theodore, $\mathrm{PhD}$, is an Associate Professor at the University of Illinois at Chicago, Urban Planning and Policy Program, Chicago (IL/USA). His fields of interest include low-wage labor markets, critical policy studies, and informal economy. 


\section{Index}

administration $56,59,64,94,100,132$, 134

Africa 64

Austria 14, 20, 41

Belgium 14, 20, 41, 45

Brazil 14, 53, 63, 64, 67, 68, 69

bureaucracy 132

case $14,15,28,38,39,40,44,48,55,57$, $58,63,65,68,74,76,77,78,81,82$, $84,89,90,91,93,97,101,102,103$, $105,110,114,116,119,129,130$, $131,134,135$

claim $23,30,44,74,76,101,110,111$, 119,130

contract $22,26,64,82$

disability $12,24,47,48,74,82$

disciplin $10,80,93,103,112,130$

drug $15,26,89,90,94,96,100$

economic $16,21,24,25,27,28,29,32$, $46,48,49,56,58,60,61,62,63,72$, $73,83,85,89,90,91,92,93,94,95$, $96,97,100,101,102,103,104,105$, $127,128,131,137,138$

ethnos 24,92

family $16,24,27,28,37,38,39,40,41$, $42,44,46,47,48,49,50,79,104$, 128,132

France 14, 17, 20, 41, 42, 43, 45, 46, 47, $48,49,122,127,128,130$

gender $40,41,43,46,89$

Germany $14,15,16,17,20,41,42,43$, $44,45,47,48,49,50,72,73,74,75$, $76,78,79,80,81,83,85,109,110$, $113,114,122,123$

governance 26, 29, 89, 92, 95, 104, 137

Great Britain 17, 106, 110, 122 institution $94,95,105,128,132$

law $9,20,28,74,77,79,81,82,103,130$

Mexico 20, 53, 54, 55, 57, 59, 63, 68, 69

money 42, 57, 77, 99, 100, 103, 121, 129

neo-Liberalism 19, 21, 26, 57

path dependency $14,22,48,50,100$

poverty $10,11,15,41,53,54,55,56,57$, $58,60,71,72,74,75,76,77,85,89$, $90,91,92,93,94,95,96,100,105$, 127

prison $15,24,93,95,96,97,98,99,100$, 101

profession 105,111

race $89,90,96$

responsibility $14,20,25,28,32,37,38$, $39,41,53,61,62,79,80,82,83,92$, $97,99,104,115,131,135$

self-help $15,83,84,91,92,100$

social policy $9,11,12,21,24,27,37,38$, $44,47,61,67,72,74,78,80,82,92$, $105,109,121,128,131,132,137$

social problem $23,44,76,78,79,133$, 134

social work $15,63,64,71,72,74,75,76$, $77,78,79,80,82,83,84,97,104$, $105,107,108,111,116,118,119$, $121,131,133$

technocracy 62

transformation $12,14,15,23,24,31,47$, $60,61,76,89,90,96,97,101,103$, $105,107,108,113,121$

transnationality $14,29,31,55,67$

United States of America 9, 10, 12, 13, $15,71,72,75,78,81,85,89$ 


\section{Evidence Based Youth Policies}

Marina Hahn-Bleibtreu Marc Molgat (eds.)

\section{Youth Policy in}

\section{a Changing World}

From Theory to Practice

2012. 327 pp. Pb. $36,00 €(D)$

US $\$ 43.00$, GBP 24.95

ISBN 978-3-86649-459-6

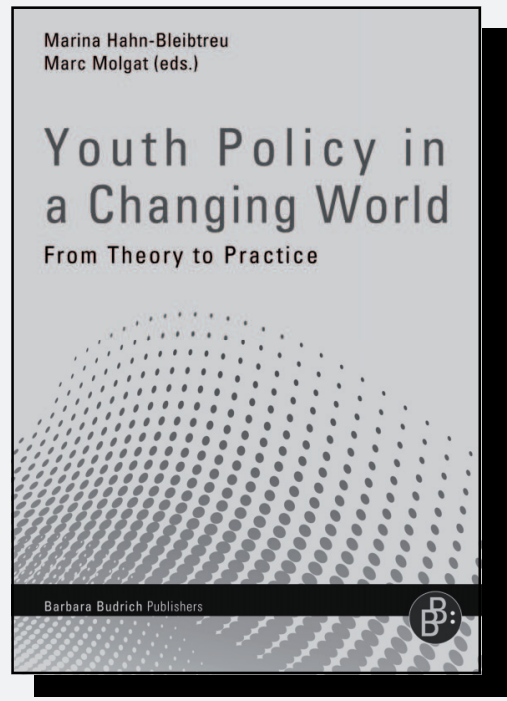

Why are youth policies necessary? What can theory and research in the field of youth studies bring to policy thinking, as well as to concrete policy and programme development for young people? International in scope, this book presents an in-depth and crosssector reflection on youth policy, in terms of theory, practice and emerging trends and issues affecting young people's lives in Latin America, Europe, Asia and North America.

\section{Order now!}

\section{Barbara Budrich Publishers}

Stauffenbergstr. 7. D-51379 Leverkusen Opladen

Tel +49 (0)2171.344.594 • Fax +49 (0)2171.344.693•

info@barbara-budrich.net

www.barbara-budrich.net 